\title{
第27回 日本內分泌學會總會並に講演會記事
}

\author{
於名古屋市商工會議所
}

昭和 29 年 4 月 $1,2,3$ 日

1. 肺切除の內分泌諸臟器組織呼吸に及に゙す影響

京府醫大舘石內科 後藤 典信, 伊藤 正夫

肺臟機能障碍時の內分汹臟器に丈ぼす影響を檢討する研究の一環として, 內分沁諸臟器特に腦下琵體, 甲 狀腺, 胸腺, 副腎, 生殖腺之の影響を組織呼吸の面より觀察し興味ある所見を得たので茲に報告する。【惯

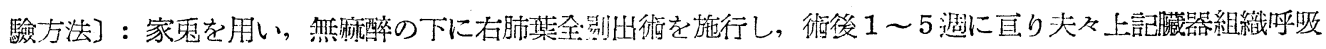

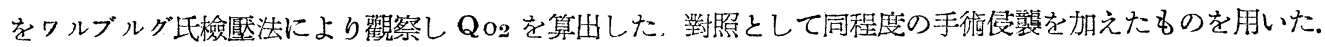

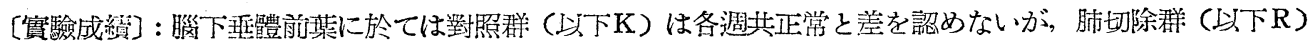

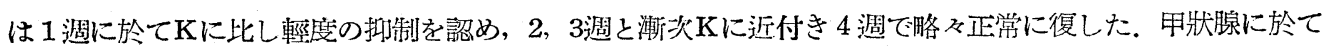
はKは 1 週 2 週 3 週と漱次減少が著明となり上後恢復して 5 週後正常に復した。 R $\mathrm{R} 1$ 週後Kに比し促進を 示して略々正常值を示すが，2週後急激に減少し，3週後稍を恢復してKに比し再び促進を示した４週以後

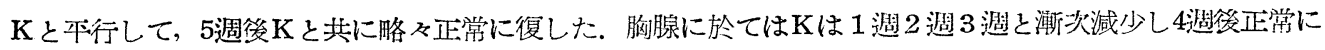
復した， Rは $\mathrm{K}$ と略及平行に推移するが常にKに比し輕度の促淮を示した。副腎に於てはKは1週後著明な 減少を示し 3 週後略及正常に復したがRは特に減少著明で 3 週後 $\mathrm{K}$ は正常に復するが $\mathrm{R}$ は侗著しい減少を示 し 4 涸後始めて恢復の徵が認められ 5 涸後も份正常に比し稍及減少を示した. 生殖腺の中睪丸に於てはKは

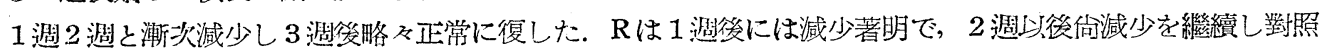
が正常に復した 3 週以後は對照に比し $40 \%$ 前後の抑制を示し 5 週後も侗正常に復するに至らなかつた。畉巢

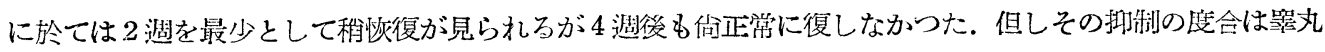
に比し輕度であつた。

2. 肺切除の內分泌臟器に及ぼす影響 : 組織變化

京府醫大舘石內科 帛田 克已, 近藤 䈭

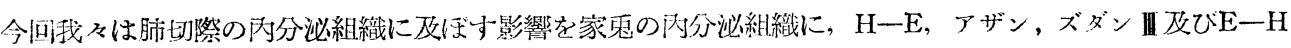

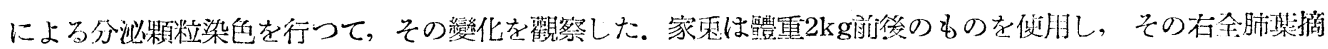

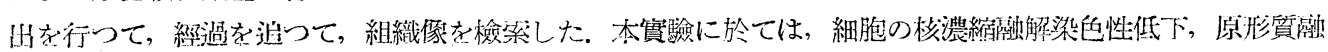
解等の退行變性が，時期的に種々の程运に現われる外一部のOrgan では循環䒺統の變化として，血管㹉張 Wand の內被細胞の肥大，增殖等，又赤血球の尣盈，膠着，陰影，确于樣物質の充盈等 Stase の狀態を見 る. 以下各組織の主な變化を述・゙る.

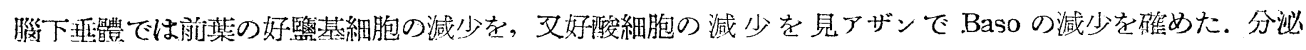
(正常)顆粒では，減少を見，後畒で，著變はなく，この變化は概ね2 4 速後に恢復する樣である。甲狀腺で

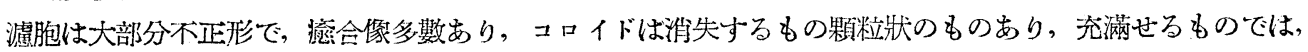

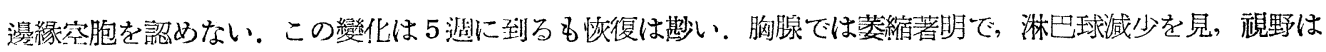

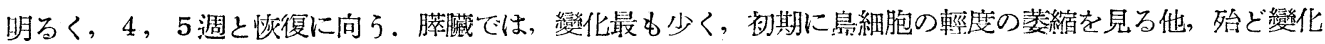
はない，分浽顆粒にも變化はない，5泪には殆ど恢復を示す，副腎では初め Z-g の巾陝少となり，細胞に

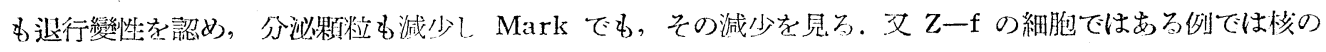


肥大を見(この例では分泌顆粒は稍及增加してる樣である)ズダン正で重屈折性りポイドの減少するのを見 ておりますがここの點に就ては更に檢討して見たいと思つて㧍ります。この變化は 4 䓢後に恢復に向万樣で あります，翼丸では經過と共に造精機能低下し，精子，精娘細胞消失し精目，精粗細胞る減少，昰より遊離

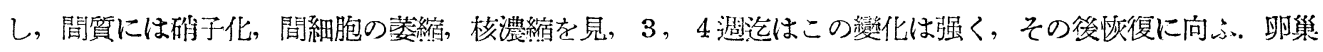
では濾胞形成能の減退を見 Primordial Follikel の Deg を見るが，Hodenに比して變化は少い。

3. 頭部外傷後の內分泌障碍について

東大清水外科 加 藤 静 雄 東宗勞琰病院 近 藤 駿 四 㔀

頭部外傷後種々の神經身體症狀をのこした㭧者について，非常に共通性がある，郎ち頭病，めまい，耳鳴，

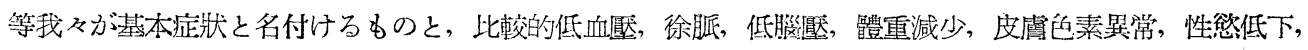
月經異常, 及び諸檢查により循環血漿量, 細胞外液量, 全體水分量の著明な減少 (少數に浮腫傾向) 等郎ち

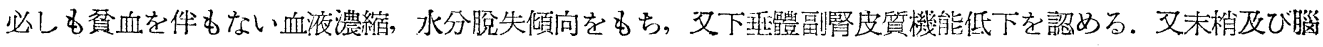
血管の彎縮, 腅實質の中等度萎縮等も高菜に認める小數に婜肝機能障碍もまり全體として體力の潐粍が目立 つてくる。これは適當に治潦せられずに長く頭部外傷性ショックのまつにされた笉の䐳及び全身機能の低下 によるものと考える．頭部外傷患者約300例について內分學的に特長の著明な例を報告するに

第 1 例 右頭項部骨折後 2 年後著明なシモンズ氏病像を呈した 24 歲の女性.

第 2 例 右頭項部及びトルュ鞍附近の蛼裂の後 $20 〜 301 の$ 尿量增加を示した 27 藏の男子.

第 3 例 Addisonismus 9 例中定型的な38歲の男子, 又一般的にみて副腎皮質不全の傾向が大であるこ とを副腎皮質不全の所見の因子分析により認めた。

第 4 例 出血性メトロパチーの所見を示し, 氣烅術により輕快した14歲の女性, 無月經がやはり氣临術に より正常月經になつた23歲の女性.

第 5 例 外傷後著明な體重減少 (本均 $15 \mathrm{~kg}$ ) を示し血液濃縮, 水分脫出, 及び負の窒素本衡著明な例 4 例 以上頭部外傷といらものが，極めてしばしば，時に立型的な內分必障碍を示し治潦を必要とすることの多 いことを强調したい。

\section{4. 放射線障害の治潦に關与る竇驗的研究}

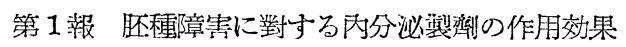

九大第 1 內科 操 坦道, 柳瀨 做幸, 不丸 秀御

A. 雌性肧種障害に關与る實驗

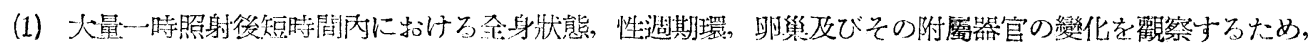

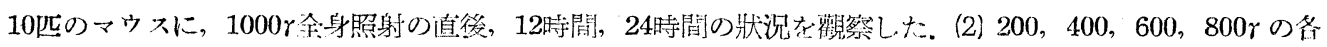

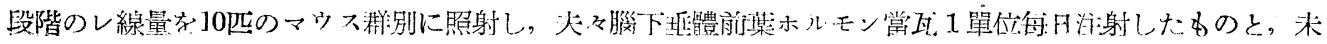
處置のものとに分ち，6日間觀察した。

a，全身障害．第 1 の實驗では1000 照射後24時間までの䦎には，白血球数の變動以外見るべきものはない，

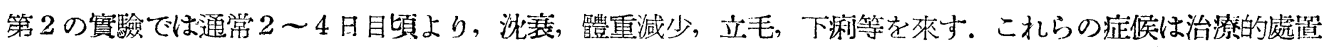
により輕減されるが，照射量が睤加するに從つて効果は著しく劣つて來る。

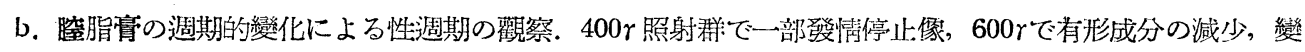
形，退縮等を見たが，治潦的効果は見出せない。

c. 畉巢及び附屬器の所見, 濾胞の破壞は成熟したもの程著明で，400r以上に見られた，600て以上では皮 質の間質に出血が認められ, 子宮, 窑の變化も著明となる。治潦的効果は濾胞の成熟に關して見られ, 200r

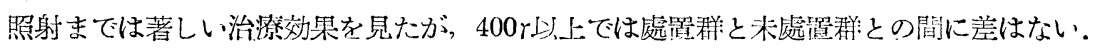




\section{B. 雄性胚種障害に關与る賽驗}

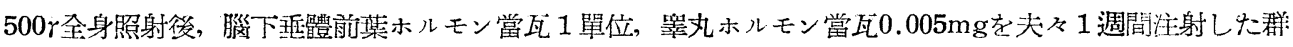
及び末處置の郡とに分ち，8 日間觀察した，罣丸及び附屬器の所見としては，照射後 6 日目から障害程度は 增加している. 治潦的効果は照射後 8 日目に見られ, 睪丸平均重量, 組織所見に於て, 處置群は未處置稀に 此し戀化の程度は輕微であつた。照射後40日目までの變化について現在追求中である。

追加

島津中央診潦所 細井 毅, 小林 秀夫, 大坂 交雄

我々はレ線照射の生體に及ぼす影誉を檢紮し，家鬼に對し 10r/Tag60日間，50さTag20日間全身照射し， 血液褒，血清蛋白分屑像，並びに尿中 17-Ketasteroids の排泄量を Beckmann-分光光度計により測定し次 の如き結果を得た。

10r照射释に於ては血清總蛋白量に於て影響は認められ無かつたが $\mathrm{A} / \mathrm{G}$ の低下並びに $\alpha$-Globulin の增加

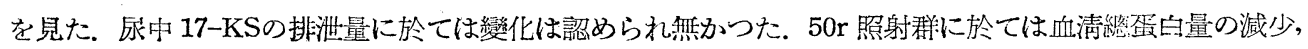
$\mathrm{A} / \mathrm{G}$ の低下並びに $\alpha$-Globulin の增加を認め, 尿中 17-KSは照射後 7 - 10日目より減少し始め, 中止後10 日目に於て輕度の烣復を認めたものもあるが，佾前值に迄は復歸を認め無かつた。

以上の成績より，レ線照射により，Steroid 代謝並びに蛋白代謝の面に於て異常を認めたので，今後この 問題に羉して檢索する積りである.

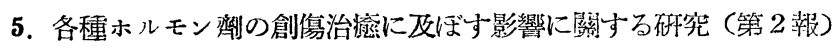

立川病院 內藤 馓德，堀江 健也，秋山千太䬦

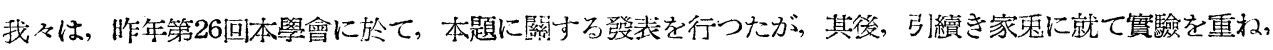

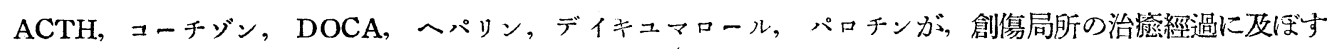
影響を檢討した. 即ち, 正常家鬼に於ける, 術後第 5 日の創傷に就てみると, 縫合創より肉芽創に對する影 響が顯著であつて,特に, コーチジン,ヘパリン, 次いで ACTH 群の, 肉芽創の治㾜經過は不良である.この原 因を究明する篇，膠原線維，銀線維，彈力線維の新生度，及び，創倁部に生成される化學的物質の，出現度 について檢討した，その結果, 上記三群に於ては, これらの線維殊に, 膠原線維の生成が琹いことが分つた. 又, 化學的物質及び酵素に關しては, 多栯類, アルカリ性ホスファターゼ, 鐵等を檢查したところ, 前二者

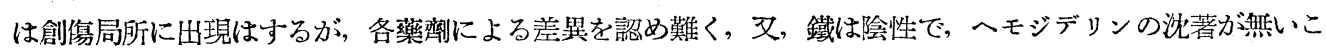
とを示している。更に，核酸についても追究中であるが，これは線維細胞の形成とる關係があるように思わ れる。次に，血液所見では，淋巴球數に對する影響が著明で，ACTH，DOCA 群は變化が尠いが，其他は

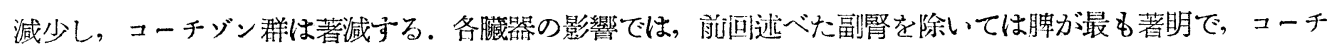

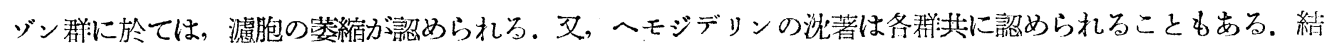

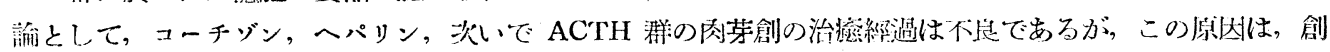

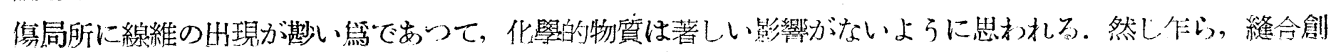

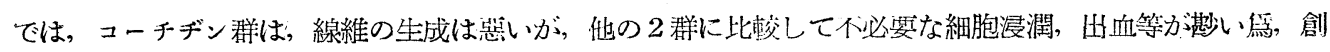
緣の接著が適確であれば，久損部の修復に線維細胞の出現を差程必要としないので，かえつて是好な成續が 得られることがある.特に，ヶロイド形成の强い傾向が認められる際には，表皮及び稘皮の細胞及び線維の

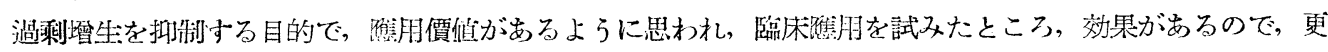
に檢討中である。

6. 內分泌㙨能と蛋白質特異動力作用

$$
\text { 東北大中树內科㨢 田一期 }
$$

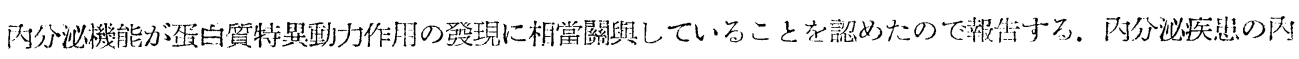




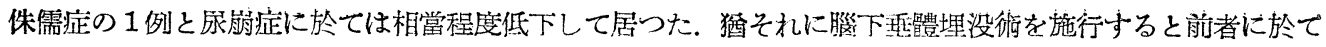
は著變を認めなかつたが後者に於ては臨床症狀の回數と共に最初低下し居たりのが洞後正常值迄上帠して居 るのが認められた，珪肺症に ACTH シモンズ氏症候啫; 甲狀腺中毒症に對して，プレホルモンを投與する と投與後いづれる，特異動力作用の上留が認められた，肺結核患者20例について Thorn-Test を行い腦下 望體副婜皮質系機能との閣聯を見ると好酸球减少率の低いものにその低下して居るものが多い樣であるが正 常なるものにも發現しないものあり，全く相關關保があるとは云えない，糖尿病患者，8例についての觀察 では2 例の元淮例を認める外いづれる正常であつた，肺結核患者18例につきアドレナリン試驗を行い、交感神 經緊張度との關係を見るとアドレナリン試獫陰性の 4 例にては 3 例が低下又は陰性であつた。瑟性甲狀腺腫 4 例では輕度低下の 1 例をのぞきいづれも正掌であつた．甲狀腺中毒症 24 例（手術前のもの）では基礎代謝 率が高くなる程發現が低下寸る樣な傾向が認められた。メチオジール治潦を行い經過を追つて見ると基礎代

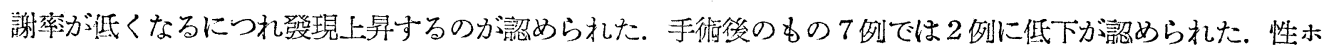
ルモン投與の影響としては肺結核㭧者に於て安息香酸エストランジォール，筋萎縮症にメチールアンドロス テンジオールを投與せる各 1 例に於て投與後著明な低下が認められた。特基動力作用の本體としての化學反 㗹を迫求する目的で二，三の實驗を試みて属るが從來の學說を全面的には認め得ない如くである。

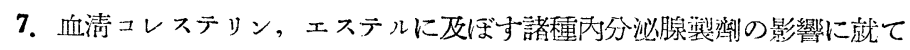

$$
\text { 京大內科第一講座三好 秋㷂, 武田 功, 笠非 皓三 }
$$

1）臨床的に推龍された諸種內分泌疾喼の血清コレステリン體重を測定するに，アクロメガソー，尿崩症， 生殖器菱樎性肥㭌症, 糖疗病にては總「コ」, エステル「コ」は健常に比し高值を示寸，副腎皮質機能不全 症にてはェステル「コ」は低い. 甲狀腺機能立淮症にては總「コ」は正常, エステル「コ」は低值を示す。 逆に低下症では，總「コ」は稍々高く，エステル「コ」は正常。

即ち，內分泌疾患時に於ては健常と翼つた「コ」體像を呈する。

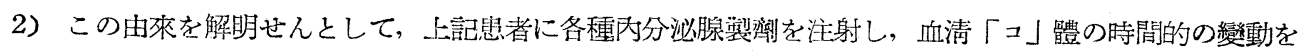

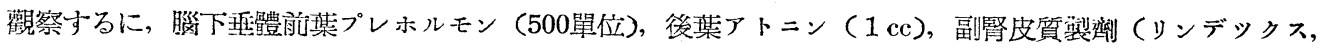
アドレレックス $2 \mathrm{cc}$ ) 及びューチゾン (100mg), ACTH (20mg) 注射後總「コ」エステル「コ」に一定の 變動を見, 之を健常型及び暴常型（著變型，不變型）に分類する事が出來た. 前記內分泌㭧者及び重症肝疾 患々者はいづれも巽常型に屬する．しかしてその變動の主軸をなするのはェステル「コ」である.

3）血淸を $37^{\circ} \mathrm{C} ， 24$ 時間放置するとエステル「コ」が增量する. からる現貌を井上呚授は血清內「コ」エ ステル合成酵素作用によるものと考え，この酵素を「コ」，エステレーゼと命名した。

からそ觀點より前記內分泌疾䁅の「コ」體量と血清「コ」エスラレーゼとの相關を見るに, 明かに相關關

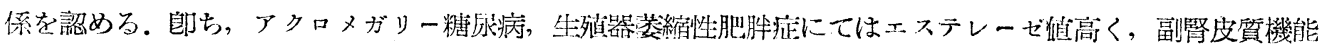
代全症，甲狀腺機能无淮奖にては低い。

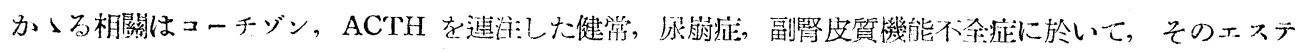

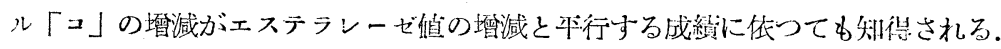

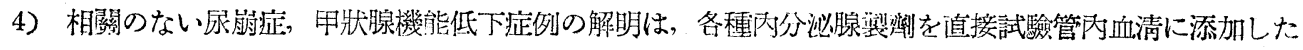
實驗に依り，兩劑が他の製劑に比し著明なるエステル分解作用を有する專實より歸䋑的に所謂脫落現貌とし て類推される.

8. 內分泌腺と神經體液性支配との關係に關等方矿究

第 1 報 內分汹矤喼と血清 Cholinesterase の消長について

東大沖中內科 吉川 政己, 宇尾野 公義, 豊田 正輝, 井林 博

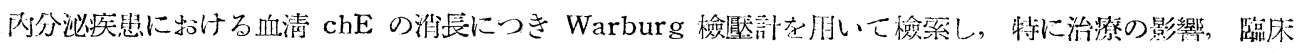


檢查成續との關傒につき若干の考察を得た。

1) 甲狀腺㙨能克進症 Besedow 氏病，合併症を除き14例中血清 $\operatorname{chE}$ の治療前に上昇しているもの 9 例, 正常 5 例で，下降例はない．且基礎代謝及びさ機光淮その他症狀高度なるの〉血清 $\mathrm{chE}$ は著しく高い. 然

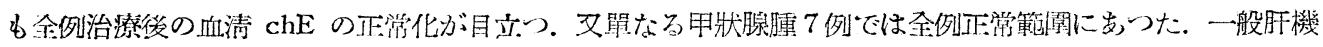

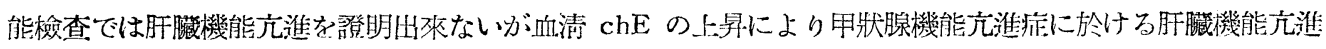
を登明し得ると考える。

2）糖尿病 本症25例中治潦の前後を通じて血清 $\mathrm{chE}$ 值の低下しもるもの16例, 正常 9 例に比し上昇例 は全くない，一般肝㙨能は殁ど正常である. 又甲狀腺の場合と異り軍輕症の差なく一般に低值で, 且治潦後

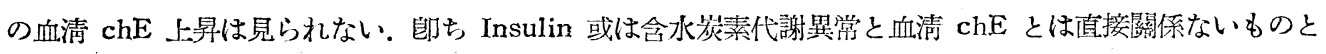
思われる.

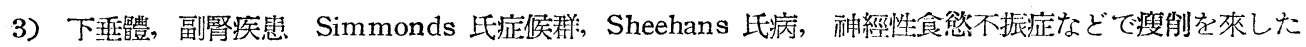
๖の 7 例，Addison 氏病 3 例でも全例正常值以下を示し，一般肝㙨能は殆ど正常だが，すべて基礎代謝低

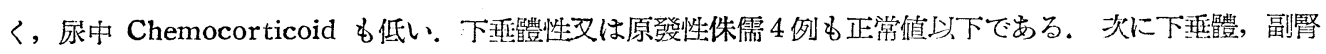
㙨能艺淮を示すと洘えられる Cushing 氏病 3 例では，2 例は正常以下，1例は上昇で一定傾向が見られな い. 肥㭌症 4 例及び末端肥大症 1 例では治潦の前後を通じ上下への變動が著しい，從つて下捶體副腎系の血 清 $\mathrm{chE}$ 支配は複新で目下檢討中である.

內分泌腺は肝臟機能を介して血清 $\operatorname{chE}$ に影響を與えると考えられ，上記成緽より血清 $\operatorname{chE}$ の測定は內 分脳腺の肝臟機能支配狀況を推察する1つの手掛りに役立つるのと考える.

追加 諸種疾患に於ける Cholinesterase activity の消長について

聖路加國際病院內科 日野原重明，橘 敏也

私共は血清 Cholinestrrase (以下CHEと略) の acetylcholine chloride の分野に基く酳酸産生の䉆の $\mathrm{pH}$ の低下度 (むpHで表す) を目標とする方法によつて諸種疾患に於ける血清CHEの activity を測定した。 $\mathrm{pH}$ の測定には Beckman のガラス電極 $\mathrm{pH}$ メーターを朋いた。 まず壯年の健康人50例の測定ではその $90 \%$

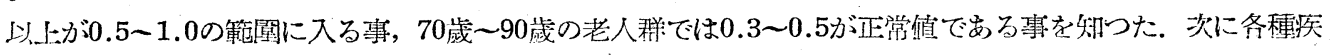

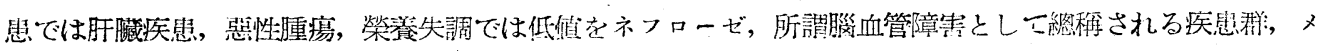
ニェール症候群，及び甲狀腺ホルモンを投璵した例に於てはい二狆も此較的高值を示す事を知つた，今度私

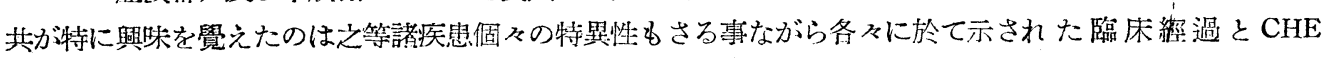

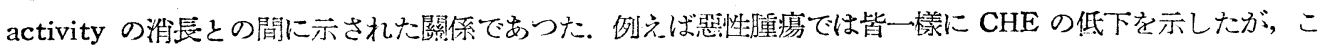
の事は症狀が相當淮んでからの事であつて, 初期には正賞值を示したものが隨分多かつた．然るに病勢の進 行と共に CHE は必ず低下寸る事が觀察された。この事は比較的長期の經過をとつた例では殊に著明で初め と終りとでは著しい差を認めた，然るに急激な轉歸をとつた例ではさして低下寸る事には異いはなかつたが 前者程著明な減少は來さなつた，之等の事は $\mathrm{CHE}$ の值を讀む時の一つの示唆となると思万．次に之等惡性 腫瘍に示される $\mathrm{CHE}$ 低下の本態であるが，一つは榮䖭失調が大きな原因である事は確實と思 万。例えば神 經性食思不振で榮養失調の鹪に死亡した例では CHE は決して恢復する事なく丁度癌の蕉行の時見たと全く 同じ經過をとつて次第に低下し逆に死の韩歸をとつた，然るに同じ榮䓹失調で CHE の低かつた慢性腸閉寒 症では患部の外科的處置によつて再び食物がとれる樣になると $\mathrm{CHE}$ は再び上㫘する傾向を示した，之等の

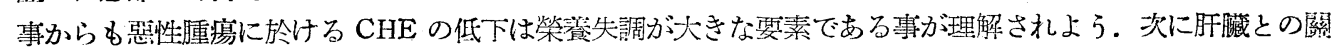
係であるが，このCHE の低下の原因を全部肝にもつて行く事には賛成するものでない，何故かならば上記 癌の諸例に於て必ずしも CHE寸見た程の變化を血清 bilirubin 值, thymol 試驗 $\mathrm{A} / \mathrm{G}$ 比等に認めなかつた

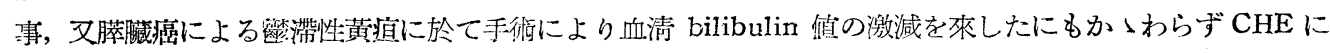
は全く上昇が認められなかつた所か却つて更にどんどん淮行忤に低下寸る傾向が示された事，更には之等疾 患に於ても最初からCHEに示された程の著しい變化を肝機能檢查に認めなかつた事等からもよく理解出來 


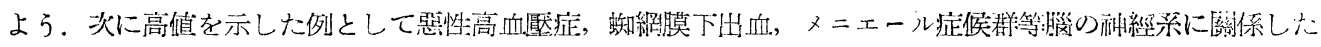
疾患が擧げられた事は興味を覺えているがその本態については全く解釋をもち合せていない，之等疾䁅に於

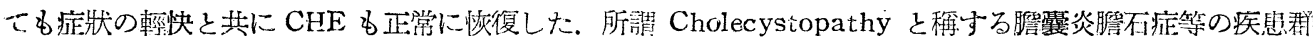

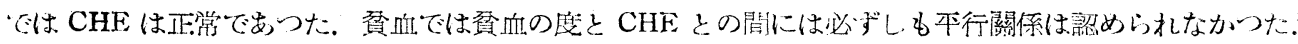

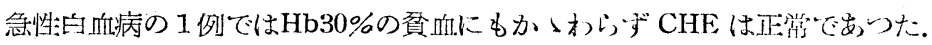

9. 抗利尿物質 (A.D.S.) に關与当研究

新潟大鳥鸰內科 小林 稔, 岩淵 耕

人血清中及び白鼠藏器中のA.D.S. 測定を.Burnの方法の變法により施行した．即ち白鼠３匹を1群とし， 被檢物は腹腔內に淮射し，90分間の尿排泄菜を以てA.D.S. 評價の基淮とした。

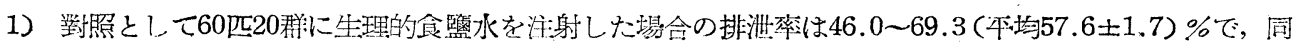
一群について 4 万至 7 日置きに數回行つた成繥にも略々同程度の變動のある事が認められた。

2）アトニンを生理的食監水に稀釋して注射した場合排澡率の變化の程度はその投與量に本行し，正常人 血清で稀釋した場合にも同程度の變化を示した。

3）自由に水を與えた白鼠群と24時間水分を禁じた群とからそれぞれ無确醉心穿刺で探血した血清につい て測定した所では, 兩者共A.D.S.を登明し得なかつた。

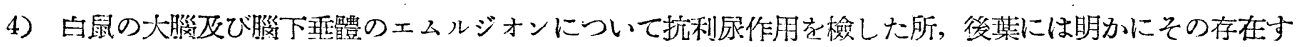
ることを認めたが，之に對し後谋以外の部分及び大腅にはその存在を認得なかつた。

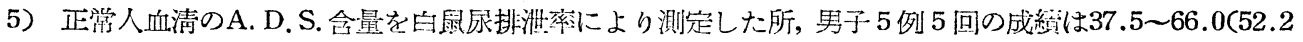

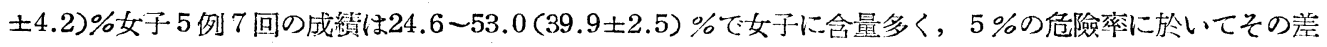
は有意であつた。

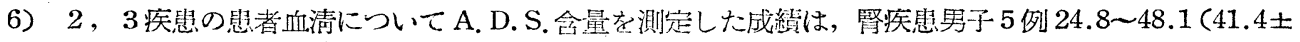
$3.7) \%$ ，本態性高血筑男子 4 例 $33.3 \sim 53.0(42.7 \pm 4.0) \%$ ，肝疾㭧男子 3 例 $17.0 \sim 55.8(42.0 \pm 7.4) \%$ ，女子-

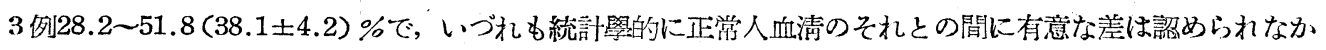
つた。 又浮腫や腹水の存否との間にも相關が認められなからた。

7）正常人及び思者血清A.D.S. 量は同一人でも月によりかなりの緣動がある事な認めた。

10. 外科領域に於ける血清抗利辰物質の䃑究

(v) 抗利尿木ルモン分泌㙨序に關与る研究(抄錄)

東大木本外科 啮澤喜守雄，稻生，綱政，大園 茂臣

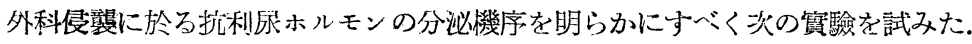

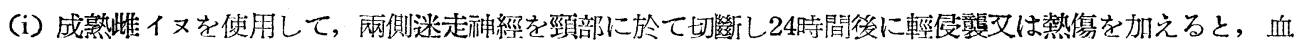

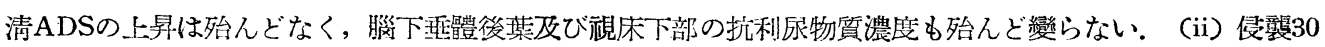
分前に Adrenaline $0.25 \mathrm{mg} / \mathrm{kg}$ 岂頸動脈より注入すると血声ADSは一時上事寸るがすぐ低下して，以後は

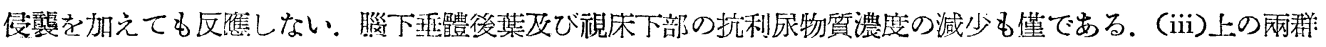

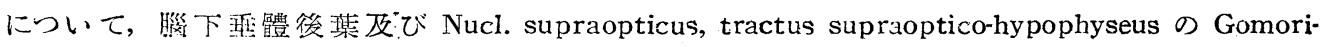
Bargmann 染色を試みた. Gomori 陽幽物質に充ちた細胞が多く認められる. (iV) 侵啕30分前に硫酸ア卜

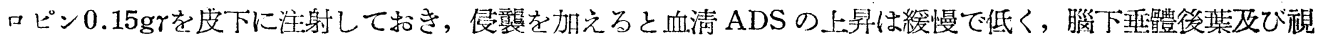
床下部の抗利尿物質濃度は中等度に隇少して居る。組織學的にもGomori 陽性物質を持つだ細胞が多少殘 つて居る. 以上から抗利尿物質の遊離は㴹走神經を介することが明らかである（V) そこで迷走神經緊張の

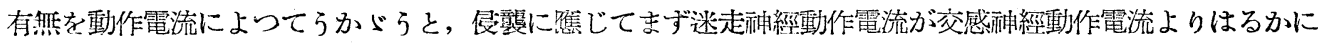
强い時期があり，且つその電流は交感融經動作電流より終始强大である. (Vi)この迷走神經紫張に一致し 
て腦下垂體後葉にアセチルコリンの遊離が認められる。次で酄分後にアセチルコリンが視床下部にむ出現し，

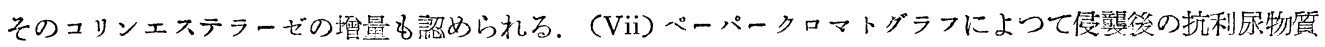
含有尿を分析すると, ニンヒドリン發㱛物質のある部に著明な抗利尿性を認める。

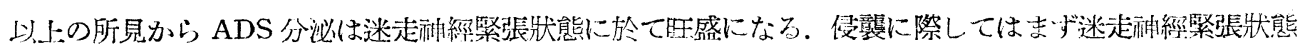
が扢こり爝下垂體後禁からアセチルコリンが遊離し，これは Nucl-supraopticus に運ばれてこのアセチル コリンの刺㦸によりADHが分泌されると解する事が出來る.

11. 外科領域に於る血清抗利尿物質の研究

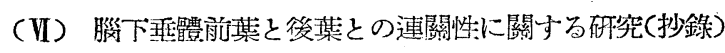

東大木本外科，龇澤喜守雄，稻生 綱政，大園 茂臣

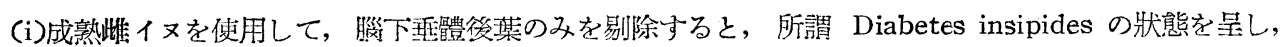

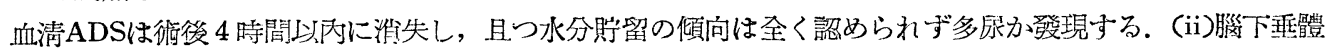
全剔除のイヌではやはり血清 ADS は 4 6 時間で沙失するが，それにもからわらず多尿の發現を見ない。 (iii) ユーチゾン $25 \mathrm{mg} / \mathrm{kg}$ 投與のイヌでは侵簀後血清 $\mathrm{ADE}$ は 6 時間にして消失し，それに伴い利尿促進が認 められる。これは然し腦下垂賗後葉を切除したイヌほど强い多尿ではない.コーチゾン注射後は腦下垂體後 葉, 視床下部の抗利尿物質濃度が中等度に減弱する. (iV)組織學的はもコーチゾン, ACTH處置により Nucl. supraopticus 及び tractus supraoptico hypophyseus の Gomori 陽性物質が中等度に減少し,

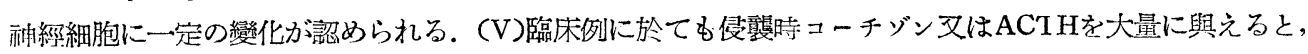
1〜2 日で血清 ADS が消失するか又は減弱し，利尿が促進されることが多い（Vi)裏弱の甚しい患者に手

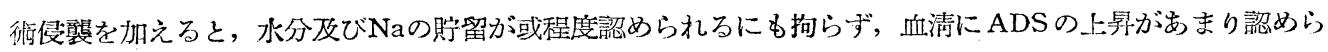

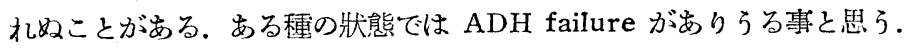

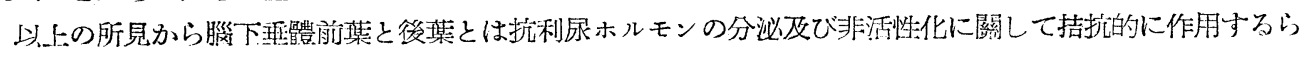
しい.

12. 外科領域に於る血清抗利艮物質の研究

(VII) ADS涨度に關係与る因子の破究(抄錄)

東大木本外科 啮澤喜守雄, 饭島 登, 稻生 綱政, 大園 茂臣

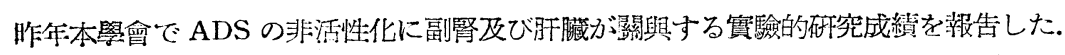

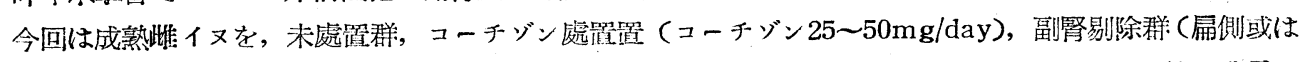

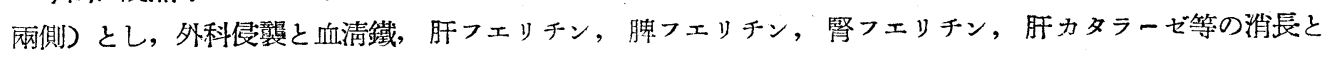
ADS非活性化との關係を追求した。

(i)肝カタラーゼの變動は各群各例によりまちまちで, ADS 非活性化との間には一定の關係が認められな かつた. (ii) 血淸鐵の變動は备々群に於て短時間では著變なく, や〉長い時間にわたつて徐及に減少する像

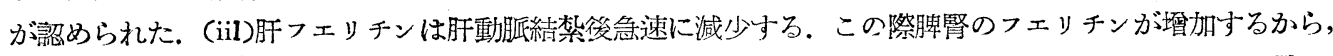
フェリチンは肝藏から逝離して血行に入るものと思われる。この場合, 血液の ADS 濃度が高く, また長く

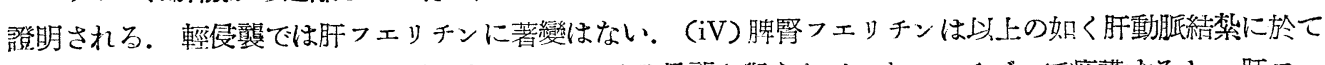

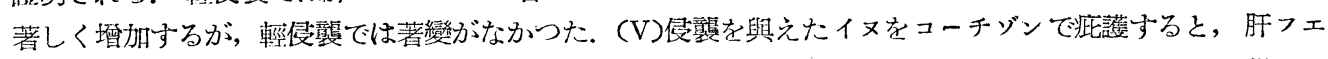
リチン及び脾腎フェリチンはフエリチナーゼによつて破墩され゙遊離した鐵はへモジデリンとなる. 從つて 血中のフェリチンはむしろ減少する。この場合血清 ADS は慬か6 時間で低濃度に證明されるにすぎない。

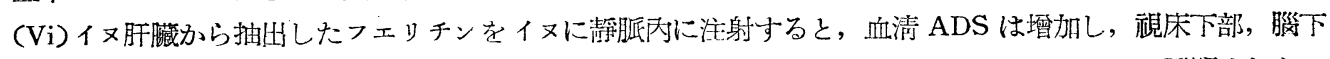

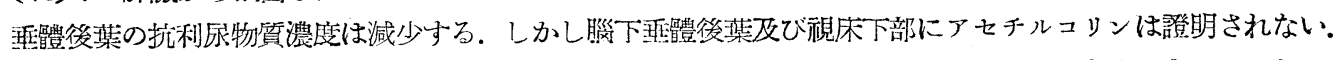
從つてVDMはADHの分汼を促すことは明らかであるが，その機序はアセチルュリンを介するものではない、 
ツ上の如く血清 ADS の濃度に關係する因子としてフェリチンの遊離及びフェリチンの非活性化が女げら れる.コーチゾンはフェリチンを破壇するので，ューチゾンによるADS 消失にはフェリチンの非活性化が 大きい關連をもつ。

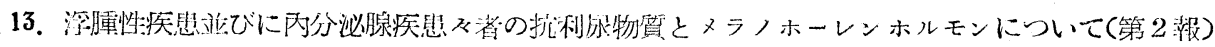

名大宇伀美內科 宇佐美鍵一，大矢 義正

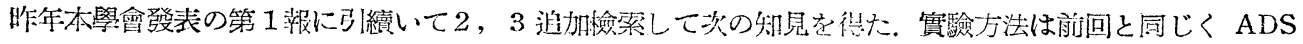
は Lloyd \& Lobotsky 氏法, メ・ホは伊藤・赤松氏法により，尿 ADS の抽出は Grollman 氏法を朋い た.

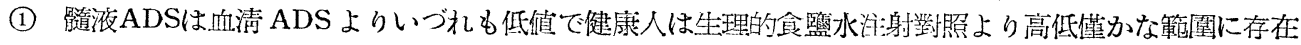
した. 浮腫性疾患では高く浫腫の虽い者程高值で，ネフローゼ，ネフローゼ加味慢性腎炎，続核性腹膜炎に

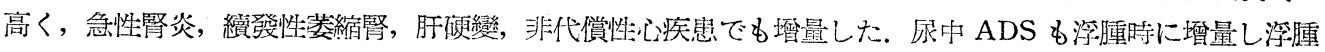

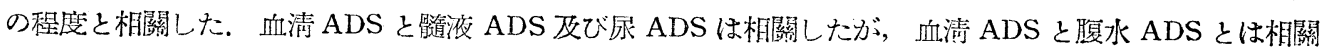
しなかつた。

(2) 內分泌腺疾患の血清 ADS は原發性乏尿症, アデッン氏病, 亞急性播種性紅玟性狼瘡その他副腎機能

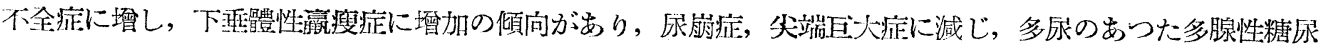

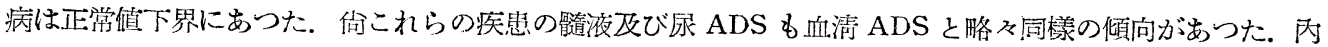

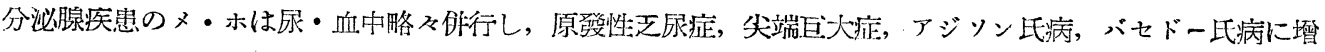

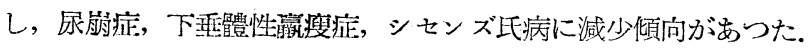

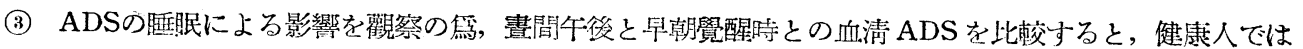

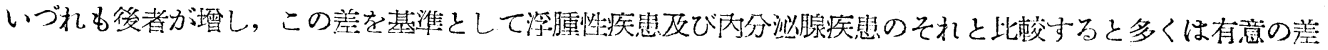

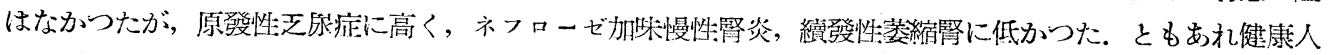
では睡眠時に ADSが壇加寸る。

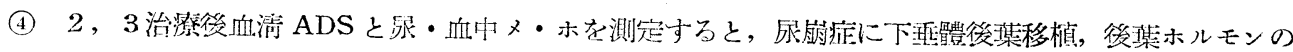

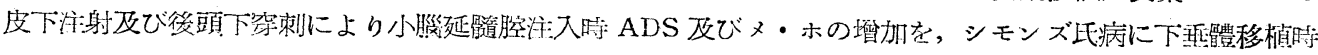

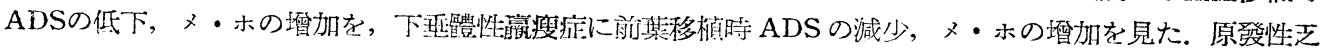
疛症の及びューチソン治潦时:ADSの低下とメ・ホの減少を見たが，間胹X線照射，前某移植時には著變はな かつた.

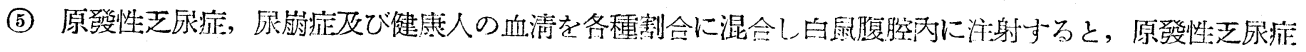

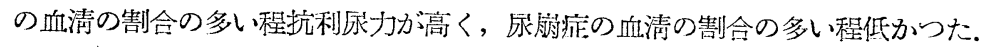

14. 血液水分量に關与る檢索

京府醫大細田內科，佳藤＼cjkstart苟，岡村 定夫

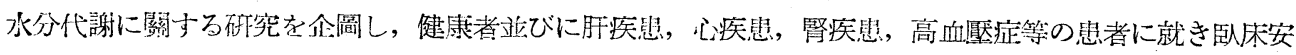

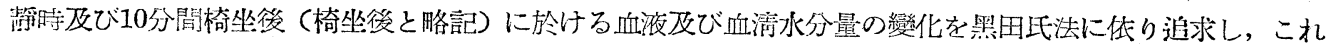
と血漿蛋白質量及びその電氯泳動像，血液酸素抱合能，血漿ビリルビン及びュレステッン量等との關連を檢 討した。

血液水分量は上記疾舁特に腎, 肝疾腎に於て墰量し，椅坐後に於ては概わ減少即ち血液の濃縮を示し就中

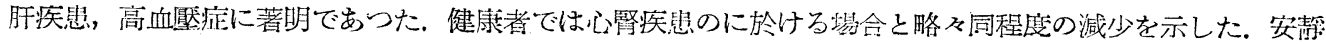

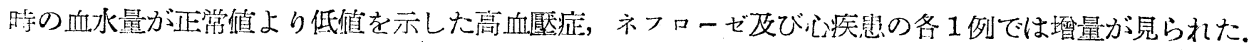

血湾水分量は高血厴症，肝，腎疾㭧では高值をとり，特にネフローセに於ては著しい. 又椅坐後では減少 し，その度は高血厴症，肝疾蝟に於て著眀であつた，健康者でも心，留疾患と略々同程度の減少を示した， 


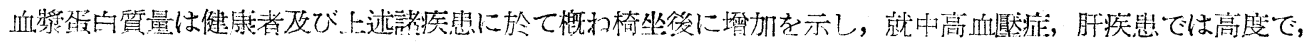

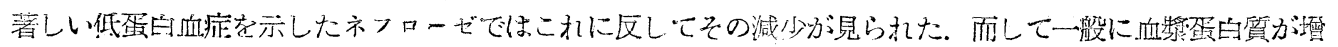
加する場合には血液及び血清水分量の減少が著しい傾向がある。

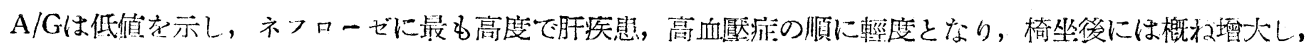

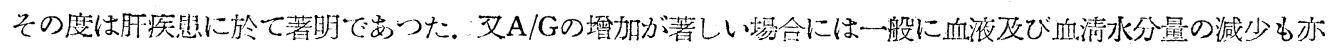
高度なることが多くこの際アルブミンの䜖加と方が大きな役割を与めると考えられる。

血液酸素抱合能は血液水分量が增加する腎, 肝疾息に於て減少を示したが，椅坐後に於ては一船に增加傾 向を認めた。

血墏ビリルビン及びュレステリンの椅坐後に於ける量的變化は區々で，これらの變化と血液及び血淸氷分 量との間に一定の關連が認められなかつた。

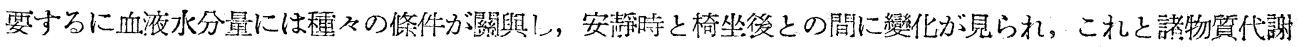
就中蛋白代謝との間に密接な關係を䌡明した。

15. 老年・者に打引る Robinson-Power-Kepler-test

$$
\begin{aligned}
& \text { 名大環㸴小川研究室 不原一期, 大 野幸 } \\
& \text { 名大日比野內科南川豊 }
\end{aligned}
$$

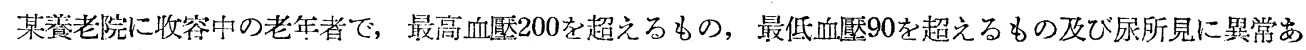
るものを除いた62〜82歲の28例を對象とし，主として Robinson-Power-Kepler Test を用い，これに ACTH, Insulin, Epinephrine による流血中好酸球の Response の翟察を加えて, 老年者に括ける內分泌 性調節について一宗の所見在得た。對照として本研究室員 6 名(24〜30歲)を觀察した。

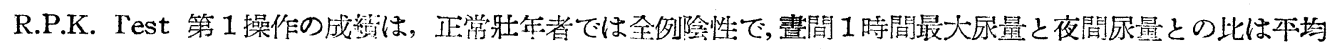
2.203 であつたが, 老年者では陽性で, 床均0.57を示し，秃われの經驗した Addison 病と同樣な值がみら れた. test の條件下で體軍 $1 \mathrm{~kg}$ 賞り $20 \mathrm{cc}$ の水を負荷した後の水利尿の扢こ方を比較した處, 訝年者では負

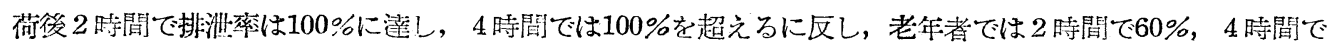

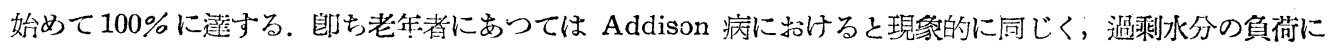

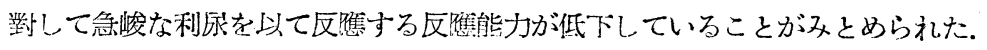

第 2 操作では，夜間尿尿素濃度と血漿尿素々の此は老年者では26.8, 訝年者では47.4で, 老年者の方が小

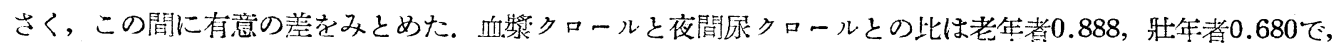

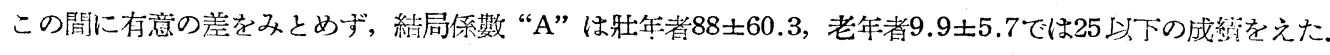

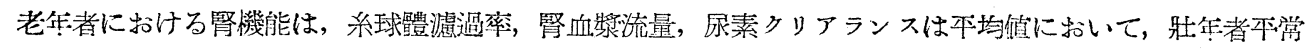
値よりも僅かに小であつたが, 正常限界內にあり, 病的な值を得なかつた。

流血中脄酸球の response は ACTH に對しては normal, Insulin に對しては hypersensitive, Epinephrin に對しては異常な response を示した.

以上の所見よりわれわれは老年者において，下垂體前祡の機能低下を推定するとともに，簡單な Water test によつて，老年者の內分泌性調節の一班を窥い弓るものと考える.

16. 老年者の內分泌機能に關与歹咑究 第 1 赫

$$
\begin{array}{r}
\text { 浴風會 大 } \\
\text { 野 文 俊 } \\
\text { 真大冲中內科 北林 博, 西川 光夫 }
\end{array}
$$

（1）副腎皮質機能 60 歲から94歲に亘る 57 例の健康老年・者に就き尿中 Chemocorticoid を中尾法で

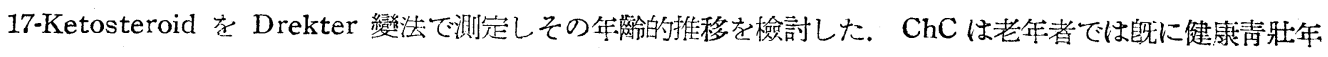
に比して低下しているが60歲以後に於ては年砱による低下傾向を見られず一定の排洲レぶルを示す，之に反 


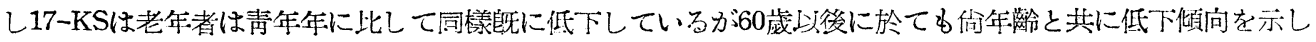

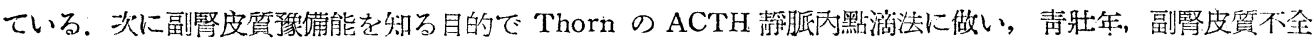

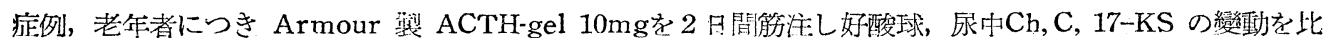

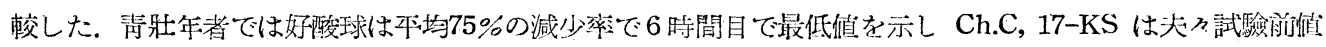

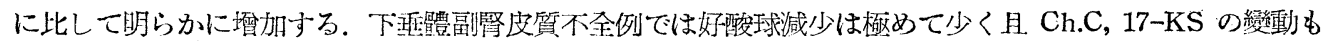
全く見られない，老年者では好酸球減少はー75\%の良好なる減少率を示すが最低值は注射後 8 時間のものが 多い. Ch: C, 17-KS は之に反して全く增加を示さない. 以上より老年者副腎皮質機能に關し炏の結論を得

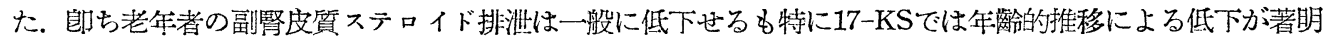

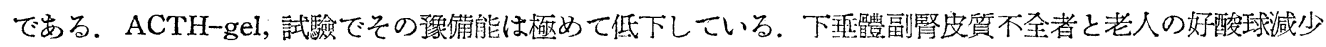
態度の羑については意義は不明であるが極めて興味がある.

（2）老年者の P.B.I. Barker 灰化法により健康老年者の P. B. I. を測定せる結果その本均值は 3.87r/dl で同時に测定せる健辱青壯年者立びにバセドウ病の值に比して低下せるもの多く甲狀腺機能低下症例に近い

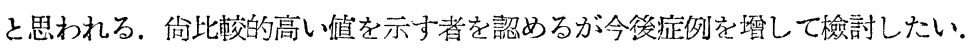

17. 甲狀腺㙨能不全症の B.M.R. (Basal Metabolic Rate) 及び S.M.R.

(Somnolent Metabolic Rate) の測定に就て

大阪市大小田內科 藤田 榮一, 川口 自由, 河南清入郳

甲狀腺機能失調の診斷に重要なB.M.R.の測定が，心身不安や测定の不馴れ等で大きな變動をきたし妿く，

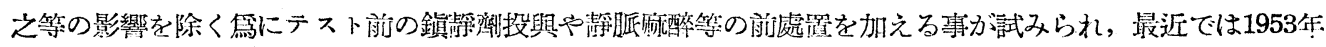

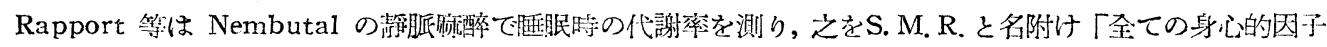

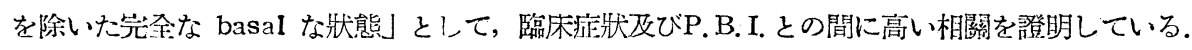

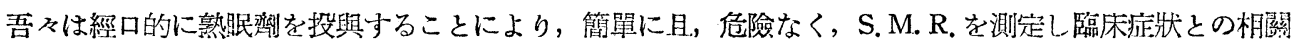
性を檢討した。

〔檢查方法〕朝涊食, 安靜臥床30分後B.M.R.をクニッピングで計り，熟眠劑 Rabona 2錠投與後，眠る のをみきわめてクニッピングでS.M.R.t測定した.

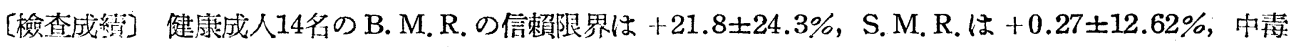
性甲狀腺腫症17名の測定值を之と比輘するとB.M. R. は17名中 5 名，S. M. R. では17名中15名が健康人の信 賴限界より外にあり， $\chi^{2}$ testにより两者の間に有意の差を認めた。

刃, Euthyroidism 7 名, Methiosil, I 131, 手術等の治潦經過を 5 名について測定し, S. M. RがB. M. R. よりもよく臨床症狀に一致することを確めた。

〔む寸び〕從來の方法でB.M.R.の正確な值を得るには嚴格な注意で安錚狀態におかねばならないので，

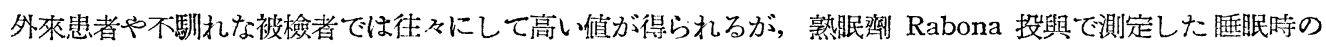
S.M.R.を以てするとさほど嚴格な注射をしなくとも，從來の健康者の標準，並びに患者ではその臨床症狀 に一致する傎が得られる。

18. 女子結核患者基礎體溫に關与る觀察

千大第二內科 鈴木 身洋, 千葉 䚄鄉, 三宅 一郎

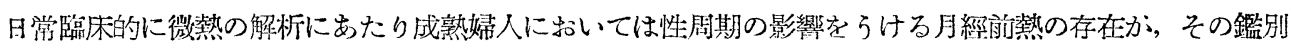
彰绦を困難ならしめる。

われわれはこの問題を檢討する目的で，18〜50歲の成熟結核婦人152名より得た625周期の基礎體溫を分類 し，結核症との相猎性を統計的に吟楽してみた。

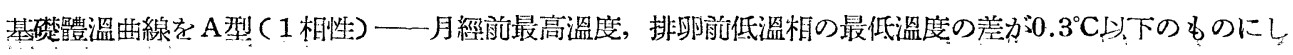




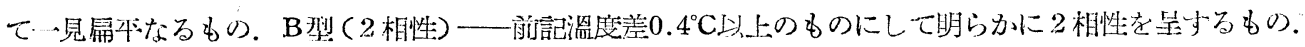

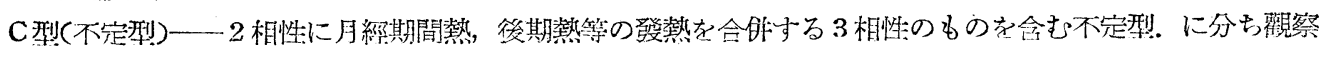
L.た.

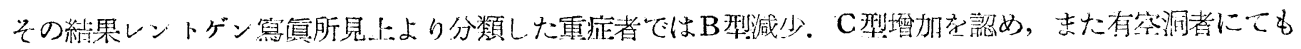

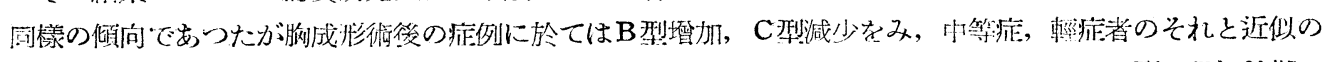
絓果を得た。次にB型㭧者については病勢と發熱期間, 弡熱度との間には相關はなく, この型の月經前期に 拝ける高體溫狀態は黃體ホルエンの熱因的効果に基くものと考えられる. 重症者にC型の多いのは, 黄體機 能不全によるものか，或は(B型の體溫) +(結核固有熱) +(混合感染 $)+($ 體液的种經的易發熱條件)と言つた， いくつかの因子よりなる發熱を示すりのと思われ，A型の出現は結核弡病以前の畉巢機能低下狀態の繼續， また結核症による畉巢機能低下と解すべきである.

しかしてB型の高體溫狀態を示すものは，いわゆる結核㭧者の生物學的免疫狀態の安定を示寸ものであり， C 型及びA型ことに前者はこの狀態の不安定性を示す一つの警告とみるべきであろう。そして從來結核熱と

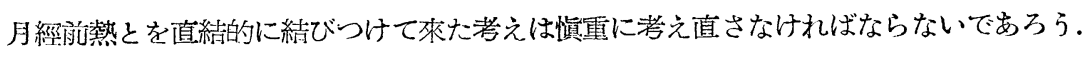

19. 結核症の進展に及ぼすホルモン及びビタミンの影響

名大豫防醫學 岡田 博, 西谷 强

H37RV を經氮道に感染させ， 5 日後からV.Be.VK，インシュリン，畉胞ホルモン等を 2 日間隔で皮下に

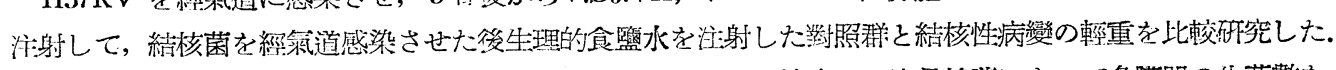

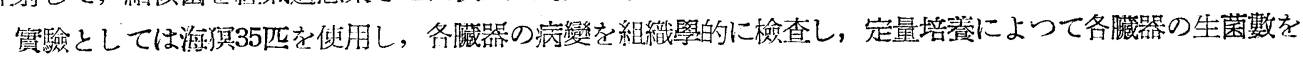
調らべ，又電筆泳動法によつて血清懇白分㞕の變化をみた。

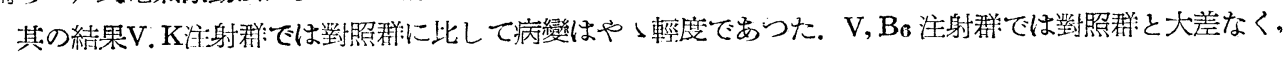

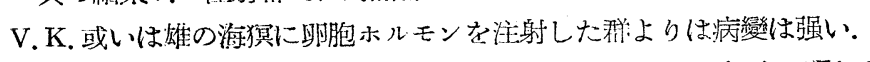

インシュリン注射群では一般的に病變は對照䂜よりや〉輕度に現れたが個くの動物ついてみると或る動物 では病變が輕く，他の動物では病變の强いものもあつて成續は必ずしも一定しなかつた。

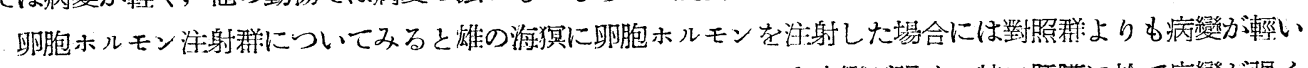

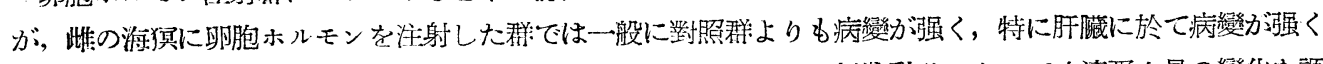
現れた。定量培站によつて各臟器の生菌數を調らべた結果, 及び電氣泳動法によつて血清蛋白量の戀化を調 らべた成縝も大體病變の强度と一致した成精を得た。

ホルモン, 或いはビタミンの作用は其の便用量と使用量と使用回數或いは洋射される動物の其の時の狀熊 によつて現れる結果は必ずしも一定した結果が現われるとはいえないが吾々の伐用した量と間隔では以上の ような結果が得られた。

20. Stress に於ける血漿趣巨管

名大環研小川研究室 小川簏, 鈴木 伸夫

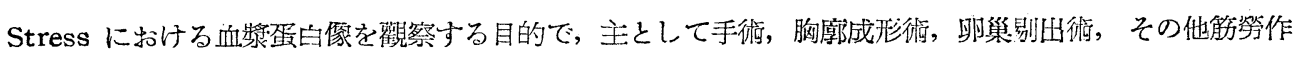

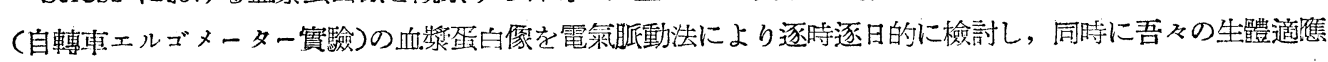
指標( 小川膠質反隹OY, 稘糖一總還元力率 $\mathrm{G} / \mathrm{TR}$ )に照して考察し, 倫 $\mathrm{ACTH}$ 投與にむける血漿蛋白像と比較 した.

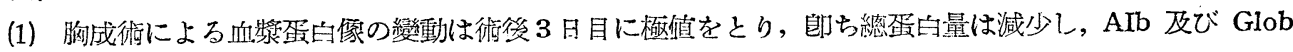

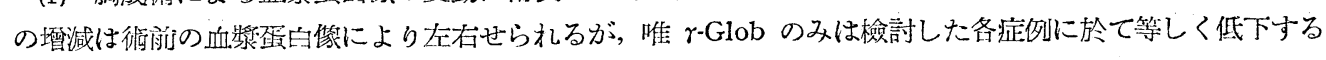
のを認めたＯOY, G/TR よりみて之は Stress として著しく强度の場合と見做された.

(2) 畞巢別出術に於ける血將蛋白修は(1)の場合と同じ傾向を示したが倠 $r$-Glob のみは上昇を示し注目 
されたＯY, G/TR は輕度の上昦を示し，Stress の强さは邻者に比し輕度である.

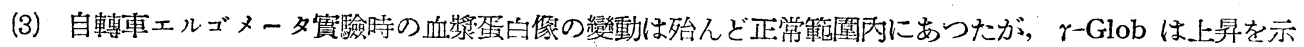
し, OY, G/TR る輕度の上帠を示した。

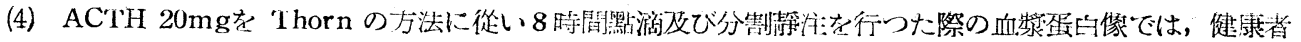

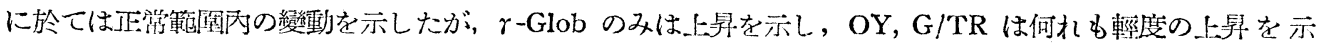

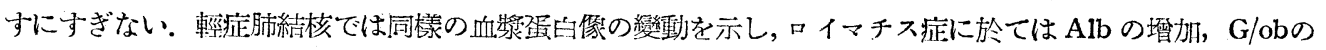
減少, A/Gの上昇を示し, $\gamma$-Glob は減少を示した。 OY, G/TR は前者に比し低值を示した.

上記の如き各種 Stress として手術例，筋焱作，更に ACTH 投與時の血墏蛋白像の變動をみると，血墏 蛋白像の變化殊に $\gamma$-Glob の堭加する場合, 減少する場合の二型があり, 之は Stress の强さ, 或はその異 常に關連するものと考えられる。

21. Stress の示標としての小川膠質反㗹數示法

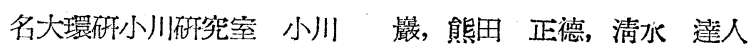

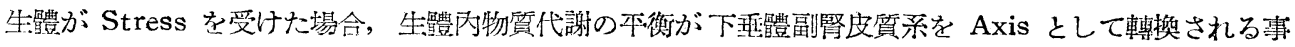
が Selye の說以來淮:目せられているが，吾々はこの看點から從來疲熒制定法として提案せられている諸方 法を Stress の尺度として再檢討する必要を認め目下研究中である. Stress は非特異性反㗹を起すと同時: にそれ自身特異性反㗹を起すののであるが，吾々はまず手術を Stress の例として取擧げ，その對象を尿に

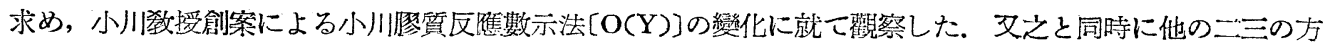
法を實驗したので之等の結果に就て郝告する. 實驗方法前びに對彖 : 胸成 I 次 30 例, II 次20例, 開腹術24例,

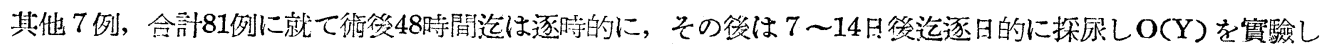

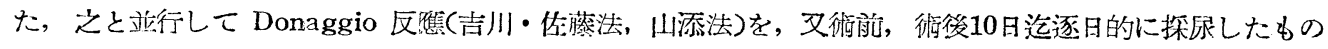
には17KS (三宅法)を測定した，向末梢血液中の好酸球に就ては直接法により測定したが，之等の結果に就 ては全て推計學的處理を行つた.

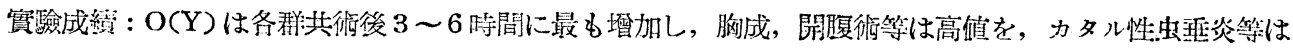

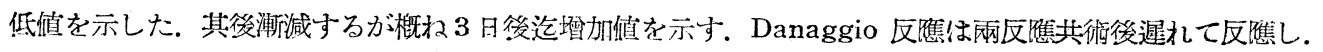

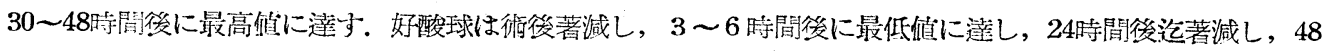

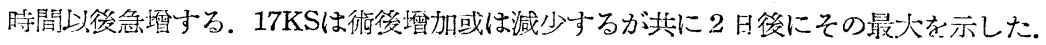

總括 : 好酸球及び Donaggio 反㗹は手術の種類による變動はみられず, $17 \mathrm{KS}$ は2 種の變動が認められた

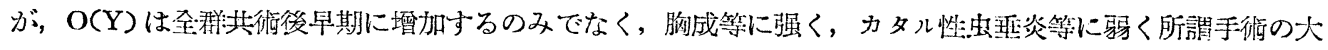
小と相關が認められたこの事は手随という Stress の强さを標示するるのと考えられる.

绱 ACTH を投與した場合のO(Y)の變動に就ては演題277にゆずる.

22. 諸種ストレス時の血液グルタチオン量の動向に就て 第 1 報 市立堺病院內科 清口 輝辰, 友淵又右衛門, 池田 隆, 中村智惠子

徤唐人, 糖㲾病, 畈炎に2〜3 Stressor を與えた時の血液グルタチオン量をWoodward \& Fry 法によ り測定した．健康人時差變動では總グルタチオンは赤血球, へマトリッット值と, 還元グルタチオンは血糖 そ略々同傾向の變動を示すが, 後者は夕に於ては整減相反する. 糖經口負荷試憸では還元グルタチオンと血

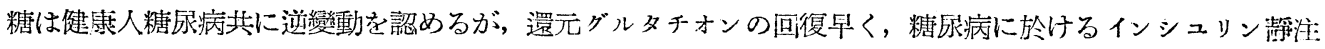
試嬐でも同樣である. 此の際還元グルタチオン，及び好婹球數の回復は血糖より早い. 肝炎のリンゲル静注:

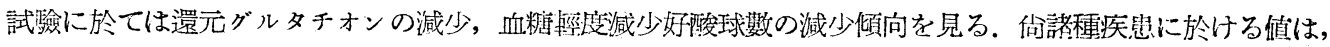

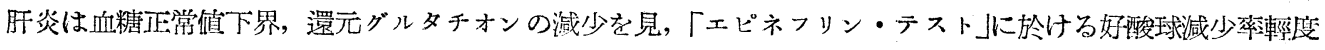
なグチヴイッ腫は還元グルタチオン，血糖共に正常值を示すが，好酸球著減せる急性帠录中毒例では無栯澴 
グ/總グ共に略々正常で白髮染中毒例では還元グルタチオンの減少を認む．以上要するに糖經口負荷，イン

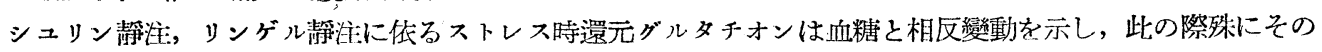
初期に於て著明である。

\section{3. 胃の Stressulcer に關する翼驗的䂺究}

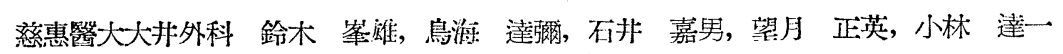

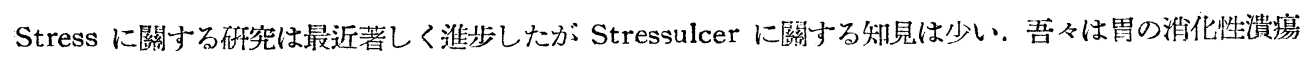

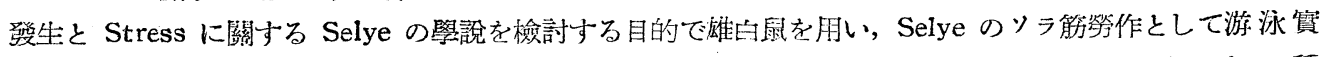
驗を行わせ，他方情緒的因子負荷として賽驗し理學的の神經症を作る賽騟赀置を改良し，電，光，音の 3 種 を同時に發生せしめて, Stress の胃粘膜及び副腎の組織, 及び胃分泌に及ぼす影響を檢索した。白鼠は無 處置群，兩側迷走神經切斷群，及び兩側副腎摘出碓:の 3 群として實驗に供した.

發生部位並びに發生狀況，筋勞作及び電，光，音によるものは $90 \%$ 以上，兩側副腎摘出群のるのは $23 \%$ に疁に Stressulcer の發生を見たが，兩側迷走神經切衒によるものには發生しなかつた．いずれい場合も Stressulcer は吾々の壁細胞分布圖に照し合せれれば旺細胞分布密度の高い部位に認められる.

組織 Stressulcer では白血球の浸潤は極めて輕微で，潰瘍底は筋板に達しないるのが大部分である。 三

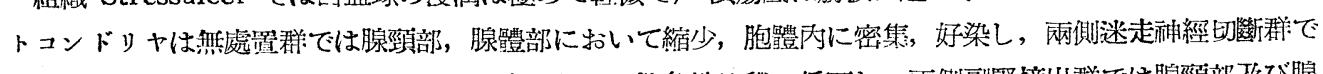

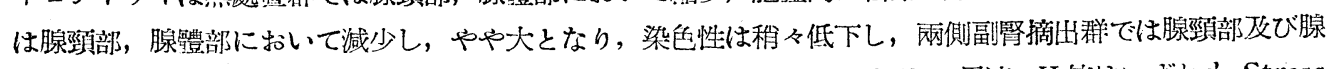
體部に执いて大小不同，染色性の低下，腺體部に著明の減少が認められる。胃液 $\mathrm{pH}$ 值はいずれ。む Stress

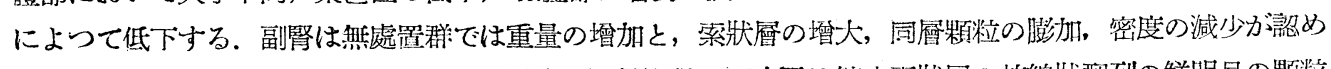

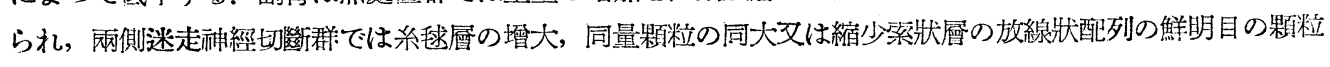
の縮少が認められる.

考案及び總括, 胃に拊ける Stressulcer の發生部位は前胃に發生する幽門結禁白鼠（shayulcer）の堨合 と暴り, 壁細胞分布密度の高い部位に認められる. 兩側迷走神經切断样のものは胃液酸度の上昇, 副婜機能 元淮が認められるが Stressulcer は發生しないから Stressulcer の發生には迷走神經の健全なることが重 要な條件となるものと思 5 .

24. 開腹術後に發生する一過性の胃痛に關寸る哳究

東邦大前婦人科 大 谷 知 寸 子

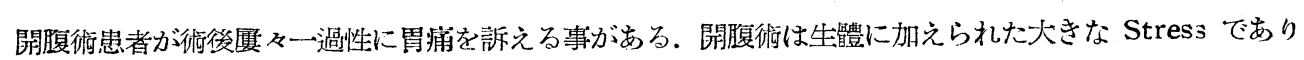

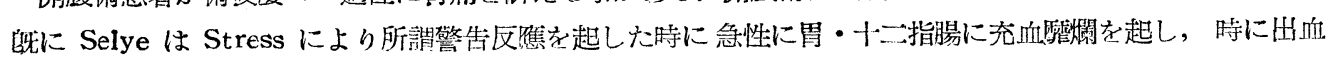
在見る事を報した，又，Selyr，Beck et al Forsham 等は胃粘膜に變化を與えるるのはACTHであると

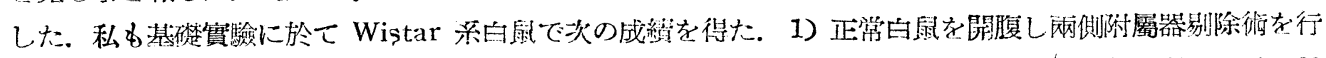

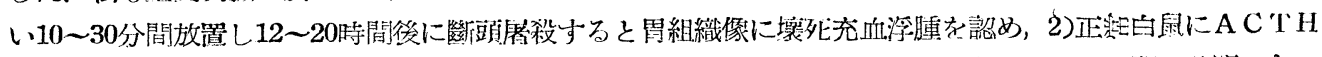
$5 \mathrm{mg} 1$ 回投與し注射後 $1,3,6,12$ 時間で虚殺しても同樣に認められ, 殊に 3,6 時間に著明であつ

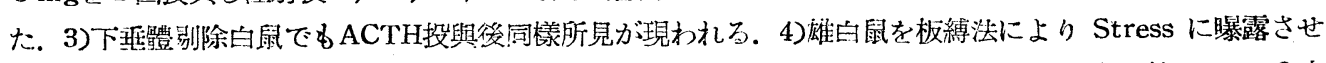
ると Cortisone 投與群は非投與群に比し著明に上記所見の㧕制されるのを見. 5)妵娠白鼠に於ては 3,6 時 間の板縛法曝露は非妊白鼠の同時間 Stress より變化は輕い。

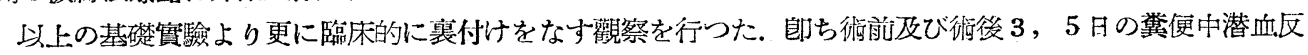

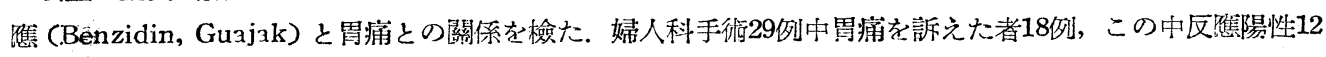
例 $66.7 \%$ (全例の $41.4 \%$ ), 疑陽性 2 例 $11.1 \%$ (全例の $6.9 \%$ ), 陰性 4 例 $22.2 \%$ (全例の $13.8 \%$ ), 胃痛を訴元

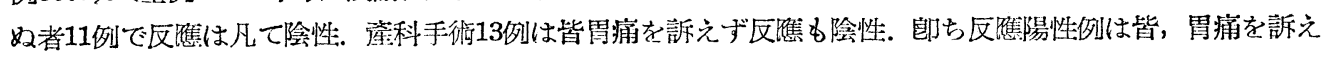

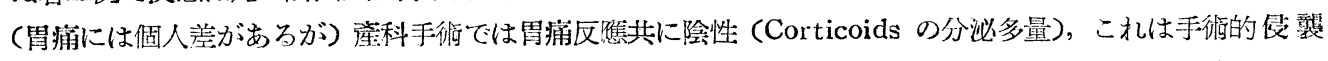




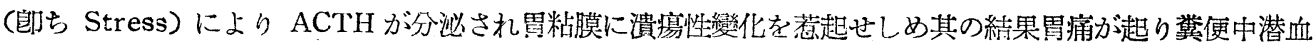
反僬を認める結果となるものと考えられ，上上の白鼠實驗及び臨床觀察から胃粘膜に障碍を與えるるのは强

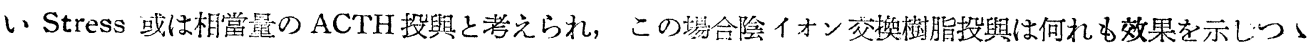
ある。

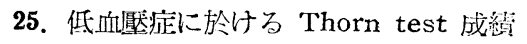

$$
\text { 徳鳥大高森內科 久次米 }
$$

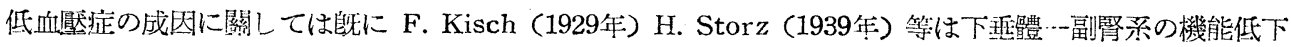

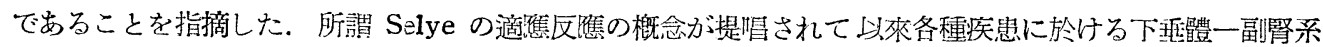
の關係が重要悓されてきた，低血厴症の臨床像が副婜機能不全の傾向を帶びてをること又副腎皮質 Steroid

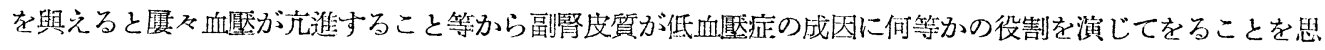

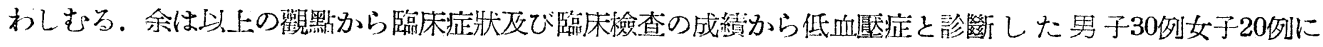
Adrenalin 法を施行した.

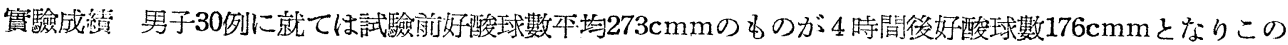
減少率 $35 \%$ ，女子20例に就ては試驗前好酸球數平均 $243 \mathrm{cmm}$ 試䛗後本均 $143 \mathrm{cmm}$ この減少率 $39 \%$ を示した.

今少しく詳記すれば

減少率男子 $25 \%$ - 30\%のもの 3 例で $10 \% ， 32 \%$ 47\%のもの 27 例で $90 \%$

減少萃女子 $14 \%$ 26\%のあの 3 例で $15 \%, 33 \%$ 49\%のもの17例で $85 \%$

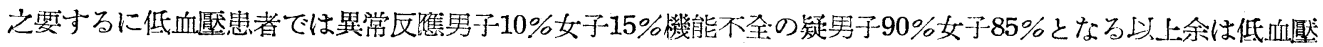
症の50症例に Adrenalin 法を惯施してその全例に於て副腎機能の低下或は乑の存することを知つたこの事

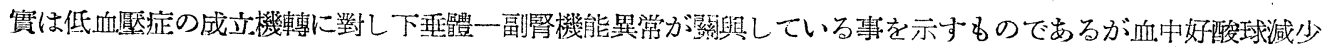
反㗹の Mechanism に關與する種及の因子は今日佾不充分である.

附記 謫文中低血厭というのは本態性低血症の意味である。

26. 高血厭と血清鐵

東京都飨育院 大島 研三, 近間 良之, 飯塚 楯夫

最近 Shorr 等によつてとなえられた血管收縮に對し促進的に働く物質 V E M と摣張的に働く物質VDM が本態性高血厭に演じている役割が問題になつている.

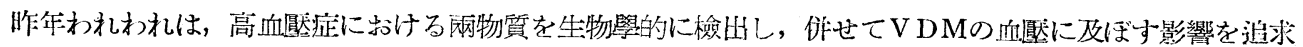
して本學會に報告した.

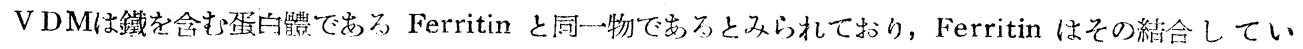
る鐵を失つて Apo-ferritin となるが，これはまた逆に鐵と結命して Herritin となる關係が存与万。從つ

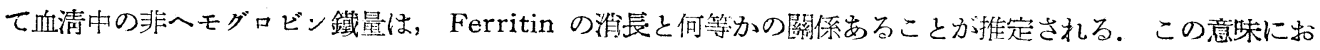

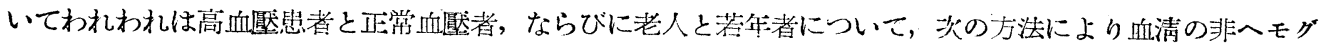
ロビン鐵量を比較檢討した，

方法は， $\alpha \alpha^{\prime}$-Dipyridyl に上る微量鐵測定洗によつた。

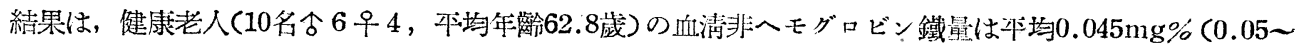
$0.2 \mathrm{mg} \%, 3$ 名 $0.05 \mathrm{mg} \%$ 以下 7名)で, 若年者のそれ( $0.095 \sim 0.165 \mathrm{mg} \%$, 平均 $0.127 \mathrm{mg} \%)$ に比し低值を

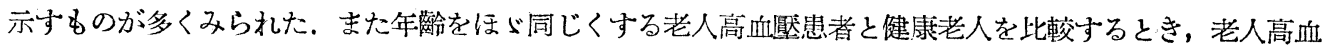

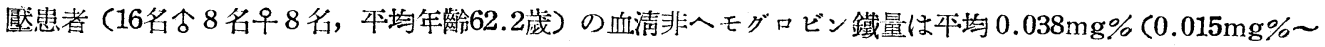
$0.070 \mathrm{mg} \%$ )で，健康老人のそれに比しや〉低值を示す傾问か久られた。 


\section{7. 高血監症患者の好酸球數に及仗す親脂性物質の影響}

阪大吉田內科 王子喜一, 小龜 正, 尾關英夫, 伊丹淳一,多田照男, 山家和雄, 海野 宏

高血壓症の成因に關しては種及論議されている。 Langecka は本症に於けるノルアドレナリン (Nor-Ad) とアドレナリン(Ad)の本衡障碍を一成因と推定し Goldenberg は Nor·Ad からAdへの轉化障碍ある事を 推論し本症はメチール基轉移障碍に值る疾㭧なりと說明している。當㸚室に於てはメチオニン其の他親近物

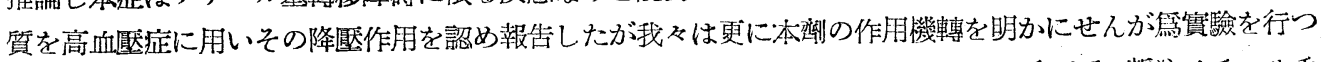

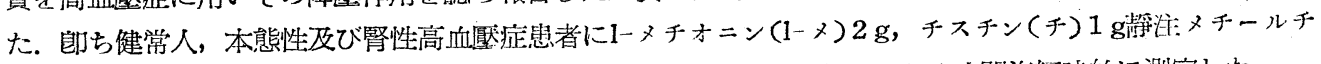

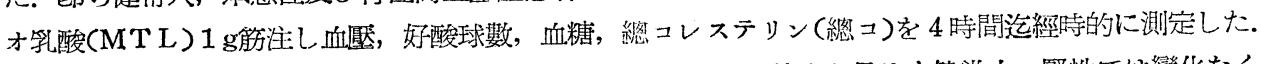

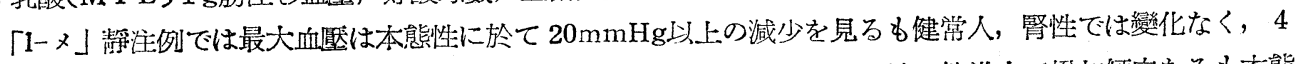
時間後好酸球減少碎は本態性 $43.7 \%$, 健常人 $12.1 \%$, 腎性では變化なく血栯は健常人で增加傾向なるる本態

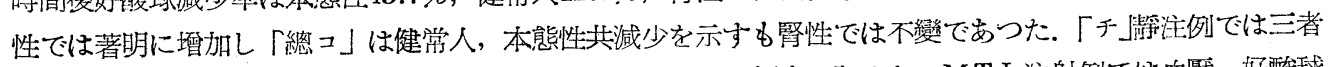

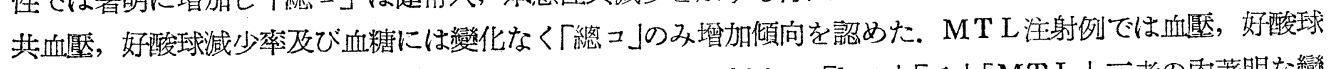
減少萃，血糖共に變化なく「總コ」は減少傾向を示した．以上の「1-メ」「チ」「MTL」三者の內著明な變 化を認めたものは「1-メ」のみで，その血胼下降，好酸球減少率，血糖增加等は Nor-Ad からAdへの轉化 を思わせる成縝である。次に本態性高血壓症にAd(0.3)及び Nor-Ad(0.3)各單獨皮注, Ad+Nor-Ad 皮注，

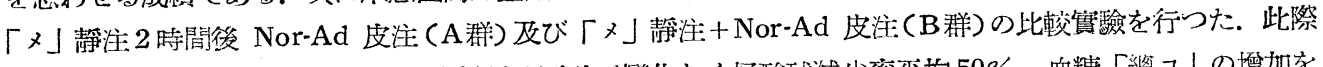

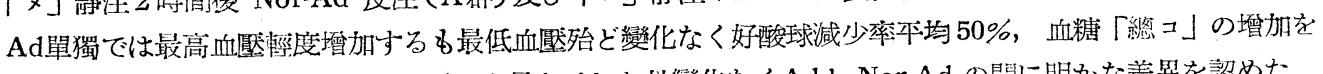
認めた．Nor-Ad は最高，最低血硻の上昇を示した外變化なくAdと Nor-Ad の間に明かな差晎を認めた。

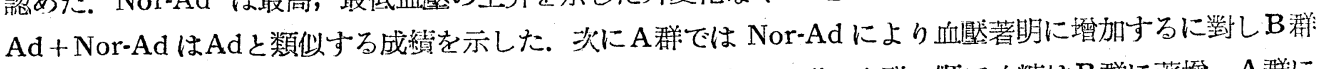

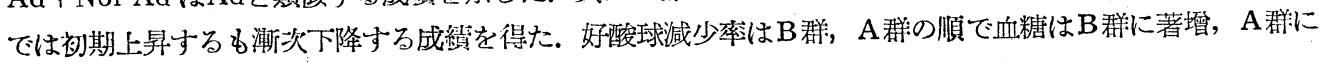
輕增を認めた。

\section{8. 胸腺肥大症に關桨学研究}

東邦大小兒科 久保 政次，四倉 健守

小兒1042名の胸部レ線單純撮影を施行し，中央陰影の異常に推大したものに前縱榢洞充氣術を施行し，32 例に中央陰影上り明かに分離した蝶翼狀の胸腺肥大陰影を認めた．之に反し中央陰影の正常なるものは胸腺 陰影を認める事が出來なかつた。胸腺肥大症の出現頻度は孚兒 $33.3 \% ，$ 幼兒 $2.6 \%$ ，學童0.8\%てて孚兒の出現 率は著明に高かつた，此等忠兒の榮養狀態はKaup の指數，身體計測值よりみるに何れも正常乃至優艮で

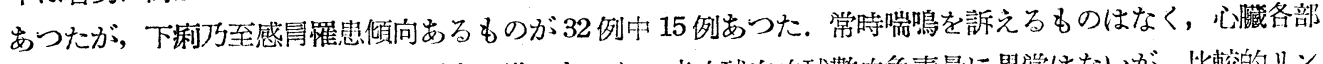

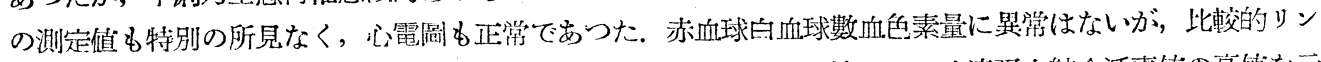

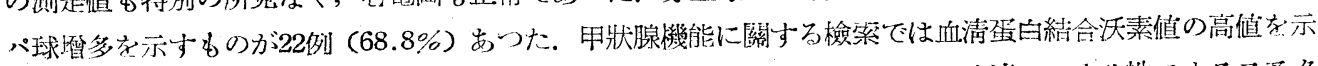
したものが11例(34.4\%)，血清コレステロールは17例(53.1\%)が低值を示し，血清アルカリ性フォスフアタ 一ゼは10例中 4 例が異常高值を示したので胸腺肥大兒は甲狀腺機能克淮があるのではないかと思われた。，胸 腺と副腎皮質との關倸に鬥してはその拮抗性のある事は動物實驗及び剖檢により多くの郝告をみるので我及

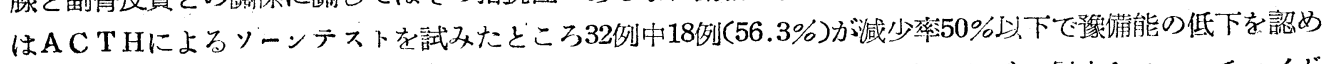
た。 血清 $\mathrm{K}, \mathrm{Na}, \mathrm{Cl}, \mathrm{Ca}$ は何れも正常值尿中17ーケトステロイドも正常であつたが，㞗中ケモコロチコイト

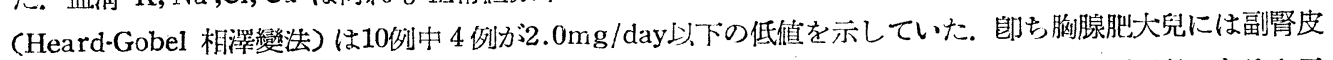
質機能障碍を示するのが比較的多い樣であつた．胸腺肥大の治潦に關しては近來レ線照射が㗀効であると云

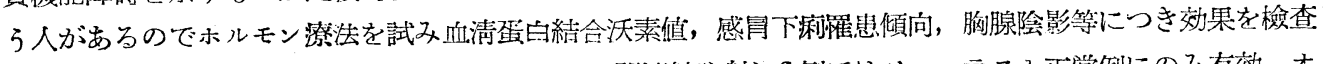
したがAC T H 健用例 (ACTH，1 日40mg10日間連結注射) 6 例ではソーンテスト正常例にのみ有効，才 バホルモン使用例（ 1 回10,000單位 1 淍 1 回 8 回） 5 例は無効で，エナルモン便用例( 1 回 $5 \mathrm{mg} 1$ 速 2 回10 
回)ではソーンテストの如何に關せず 8 例中 6 例に著効と云う結果で゙すつ\%.

29. 脾腫の核酸代謝に就いて

京府醫大川井內科 增田 正典, 田邊 茂, 藤木 典生, 瀧野 辰毁

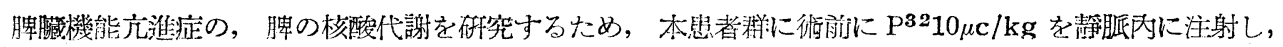
Hevesy のいう2 時間後に探血及び結紮が終るよう計畫した。かして侷出した脾についてその病理組織學 的檢攀と共に, 之を Ringer 氏液にて篧流後, Schmidt-Thannhauser 氏法によつて核酸分劃, FiskeSubbarow 氏變法によつて獜定量を行い，その笋 Hevesy 法によつて放射能を測定した。

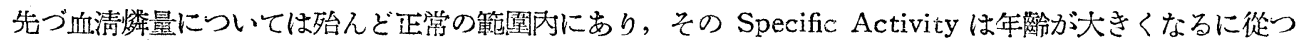
て高い.これは全身の燐代謝が年路と共に減退するものと栲える. 次に酸可溶性燐分劃では無機の Specific Activity が全燐の 2 乃至 3 倍を示している。リボイド燐分劃では著明に低下していることは谌だ興味ある 事實であり，今後の一膡の檢討を要すると考える．最後にDNA燐分劃では第 3 例を除いて殆んど Hevesy の云5正常值に近く, 從つて Banti 氏症候群の脾腫が核酸代謝の面から見て, あまり旺盛な再生現嗮を示 するのとは考えられないようである。第 3 例のDNAが高い値を示していることについては, Ahlström も 述べているように，その年鉿及び血清酸可溶性無㙨燐の Specific Activity 等を考慮すれば，或は正常で はないかと考える。

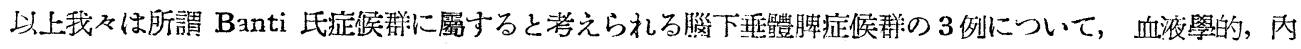

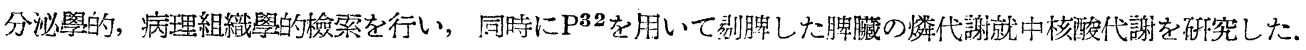

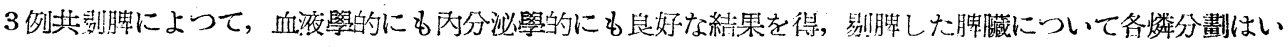
づれも年踰の若い程R.S.A.は高く燐代謝も旺盛と洘える.またD.N.A. 值は殆んど正常に近く，從つてか つる脾腫が核酸代謝の面より見てあまり旺盛な再生現杽を示するのとは考えられない。

30. 氣管支喘息の研究

群㷂大內科 七條小次毁，宮下 隆二，中澤 精二:

（1）コンニかク喘息の抗原をきめるために舞粉よりその多糖類，脂肪友で㔻白質の各分劃を抽出し各分劃 で吸入發作誘發實驗，皮內反㗹及び洃降反㗹を行つた結果は蛋白分劃に於いて何れも陽性であり，他の分劃 では陰性であつた．邓コンニャク本粉より銅マンナンを作りそれより精製したマンナンとコンニャク本粉よ りメタノール沈洪法で得たマンナンの各ふで吸入誘發實殮を行つた所, 前者は陽性で後者は陰性であつた。 次にマンナンを多く含むコンニヤク本粉水溶液と舞粉水溶淮の各々で沈降反潐を行つた結果は前者は陰性で 後者は陽性であり，多糖類であるマンナンは抗原作用が殆んどないことが分つた。舞粉の硫安による蛋白分 劃についてチゼリウスの電氣泳動法を行つた所, 蛋白は二種類あることが分らた，以上の實驗でコンニャ》 喘息の抗原は蛋白質であるつと推定される。

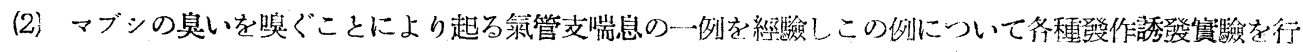
つた結果, マブシ及び蛹の水抽出液, 硫安による趣白分劃に陽性であり, マユゃワラの水抽出液では陰性で あつた。、ブシ及び蛹の硫安による蛋白分劃では皮內反陮, Prausnitz-Küstner 氏反㗹は共に陽性を示し

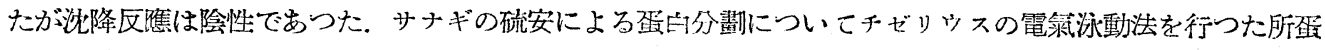
白は二種類めることが分つた。

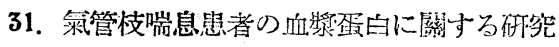

熊大體質醫學 裕田入斯

氣管枝煓息患者11例の血漿蛋白量を日立蛋白計，分劃を日立チセりウス電篓泳動装置で測定した。血液に

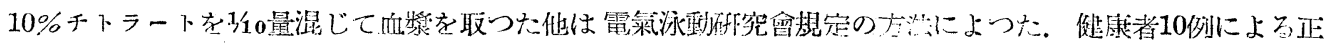


常值はG.E . : 5.75 $\pm 0.79 \mathrm{~g} / \mathrm{dl}, \mathrm{A}: 3.97 \pm 0.73 \mathrm{~g} / \mathrm{dl}(58.91 \pm 10.43 \%), \alpha-\mathrm{G}: 0.65 \pm 0.29 \mathrm{~g} / \mathrm{dl}(10.04 \pm$ $12.62 \%), \beta \mathrm{G}: 0.59 \pm 9.58 \mathrm{~g} / \mathrm{dl}(8.61 \pm 7.61 \%), \gamma \mathrm{G}: 0.9 \pm 0.61 \mathrm{~g} / \mathrm{dl}(13.98 \pm 7.04 \%), \varphi: 0.57 \pm 0.59 \mathrm{~g} / \mathrm{dl}$ $(8.41 \pm 8.61 \%)$ である。發作間晇時の患者 7 例では $\alpha-G$ 正常以下 2 例, 本均 $0.45 \mathrm{~g} / \mathrm{dl}(6.55 \%)$ で稍々減少, $\gamma-\mathrm{G}$ は 3 例が正常以上で平均 $1.48 \mathrm{~g} / \mathrm{dl}(21.89 \%)$ と墰加していた. 發作中の 4 例では $\alpha-\mathrm{G}$ は 2 例が正常以下 で本均も $0.31 \mathrm{~g} / \mathrm{dl}(4.46 \%)$ に減少し, 叉 $\gamma-\mathrm{G}$ も 2 例が正常以下で平均わ $0.61 \mathrm{~g} / \mathrm{dl}(8.47 \%)$ に減少してい

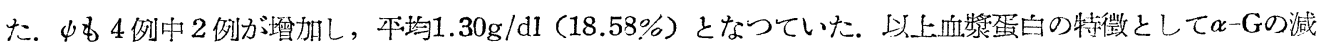

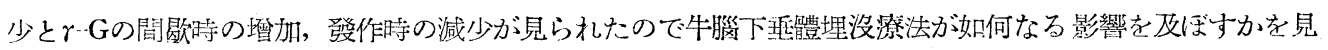

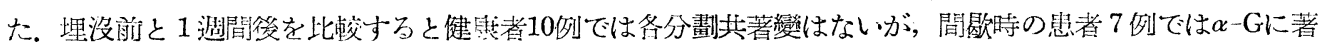

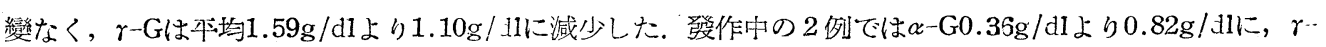

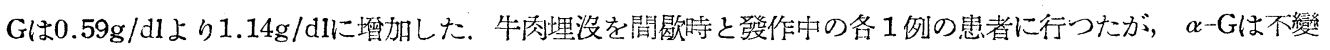

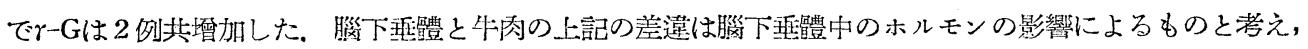

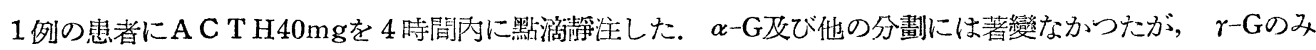
は特有の變化を示した。郎ち注射前 $1.48 \mathrm{~g} / \mathrm{dl} か ゙ 2$ 時間目に $1.13 \mathrm{~g} / \mathrm{d} l$ に減少し， 4 時間目に $1.42 \mathrm{~g} / \mathrm{dl}$ と前值 に近く堵加し，其後再び減少し，3 日後に $1.18 \mathrm{~g} / \mathrm{dl} ， 6$ 日後に $1.16 \mathrm{~g} / \mathrm{d} 1$ となつた。其後次第に增加し，18日

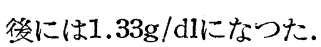

以上の成續より喘息患者には抗體が含まれる

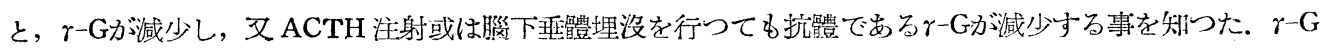
の減少郎ち抗體の減少がA C T H 注射及で腦下䫖體埋没潦法の氣管枝喘息に對する效果の重要な一因である と考える.

32. 關節リウマチ並びに氣管支喘息に對する Nitromin 及び Pylogenの効果に就いて

$$
\text { 東大分院內科 工藤 常䳸, 萩原 實, 池田二郎, 森澤 康 }
$$

Jimenez 等は Nitrogenmustard を關笁りウマチ，氮管支喘息に便用し有効なる事を報告した，余等は

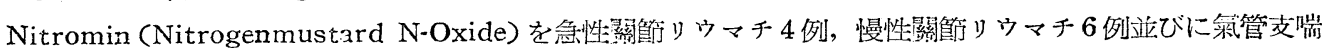

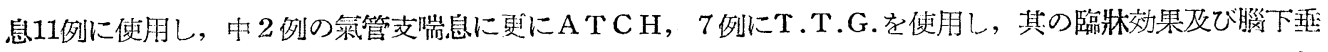
體副腎皮質系に對する影響を比較檢討した，Nitromin は20\%ブドら糖20ccに溶解し，20mg〜50mg を每: 日又は隔日に靜呱注射し，5回の注射を1クールとしたが，適宜增加した例もある。關節りウマチでは著効 1 例, 有効 6 例, 無効 2 例で, 2 例に於て血洗が著明に好軲した。氣管支喘息では著効 3 例, 有効 4 例, 無 効 4 例で治潦前肺活量, 肺換氣速度指數の減少のある者では, 治潦中明らかに償加の傾向を認めた. 効果の 發現は 2 回から 4 回目の注射で認められる例が多からたが，1间の注射で䡒快した例もあつた.ACTHと

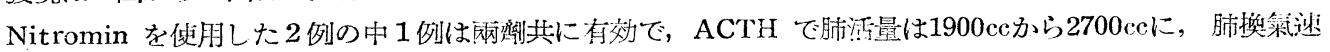
庭指數は $0.6 か ら 0.9$ 改善され, Nitromin でも略队同樣の結果を得た。他の1例では, ACTHは有効で めつたが Nitromin は無効であつた. T.T.G.使用 7 例では, 著効 1 例, 求効 3 例, 無効 3 例であつた. Nitromin の腦下垂體副腎皮質系に及ぼす影響を檢する䉆, 治潦前及び治漝中に於て此等患者の中 20 例に Thorn test, 8例に Hyaluronidase skin test を施行し，20例に尿中17-KS排泄量を测定した. Thorn

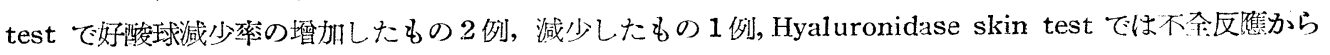
㫕全反潐に轉じたもの 1 例であつた，17-KS排洲量は 2 偣以上增加したもの6 例, 稍及增加したもの 4 例， 減少したもの 3 例であつた. ACTH, Nitromin 便用の 2 例では Thorn test は著變を示さなかつたが, 17 KS排泄量は，ACTHの方が秒及多いが，Nitromin によつても著时な增加を認めた。一般に Nitromin に

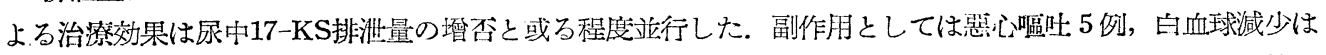

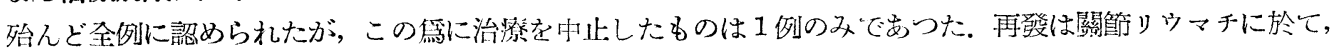

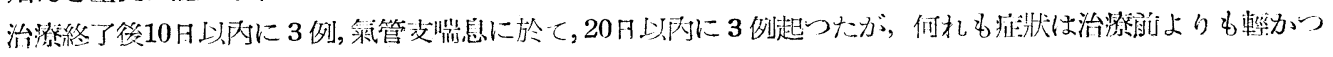


た.

33. Male Hypogonadism の臨床（第 5 報〉

東京醫葸大 志田 羑三, 石本 光秋, 武田 裕壽

1. Hyogonadotropic Eunuchoidism の治漝としては Gonadotropin 笠劑の投與が第一の適㷪であるが， 郚床上は高單位の投與が出來ず充分なる効果が期待出來奴。適當なる Androgen の投與は二次性徵の出現， 副性器の肥大とともに睪丸の發育をきたす一石二鳥の効果がある。

2. Impotence の原因には身體的要因の他に精神的要因が大きく影響してをり，その發生病理の閪明は極 めて困蜼である。身體的要因としては Androgen の父乏があげられるが，これは臨床上精液果糖量測定を 以て間接的に宜易に推定される. $200 \mathrm{mg} / \mathrm{d} 1$ 以下の症例は Androgen 投與により容易に症狀の改善を期待し ろ。

3. Androgen としては Testosterone が用いられるがその代謝はすみやかであるから投與形成にはエス テル化等の特殊の教琶が必要である (a) Testosterone propionate (T.P.), $\beta$.cyclopenthylpropionate (T.CPP.)及び heptanoate (T.H.) 各10mg投與の雞冠試驗一注射當䘞はT.P.T.H.ともに同樣の稚冠肥大 がみられる．T.P.は 5 日を最高にして萎樎するに反し，T.H.はその後も階段的に曙大し，21日に至るも

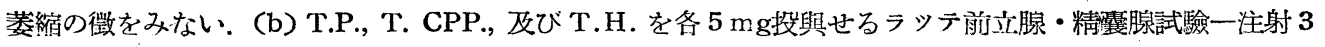
日䒺はT.P.が副性器の肥大効果に於てや〉まさるも，その後は急速に萎縮する. Depot 裂齊はその後も增 大し，T.CPP.では第 2 週，T.H.では第 3 週を最高とし，6息後に至るるな擆明に効果がのこつている. （c）1例の類宦官症にT.P., T.CPP.及びT.H.を逐炏100m g投與せる實驗一T.P.では 17-KS 排泄は2， 3 日間著しくまし，尿中酸 Phosphatase は4 日間增加. Depot 笠劑では17-KSの增加は髣徐であるが, phosphatase は7〜10日間增加がみられる．（d）類宦官症及び男子更年期障碍に於ける成續一 3 種の製劑を

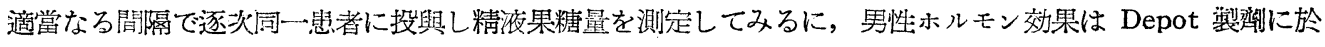
てはT.P.に比して著しくまさり，とくにT.H.が優秀である.

34. 首下り病の 2,3 の知見

九大楠內科平田幸正

佐賀縣に於ける首下り病の 1 例を經驗した，患者は30歲の男子であつて漁業に從事しており，有明海へ出 漁中に初回の麻瘵發作が起つた，その後殆んど連日發作が起る樣になり，發病の 2 ケ月後に當科へ入院した。

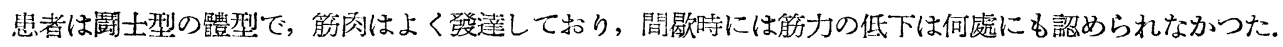

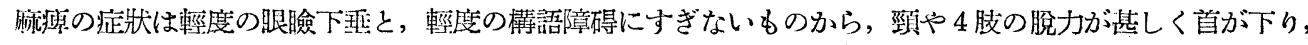
又起坐不能となり, 又開眼や發聲も全:く不可能となる重症のものまであつた。發作は一過性で㚙然起り, 又 速に輕快してしまうものであつた。

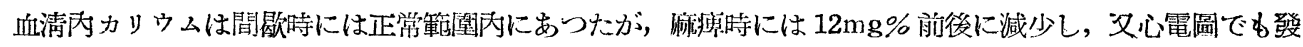

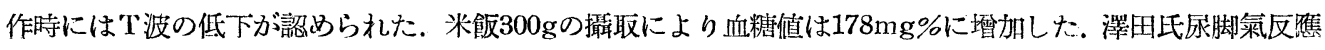
は陽性であつた．植物神經の藥効學的機能檢查ではアドレナリン，ピロカルピン，アトロピンの何れにも陽 性を示し, しかもその際に床庿發作が誘發せられた。

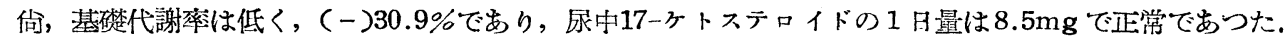

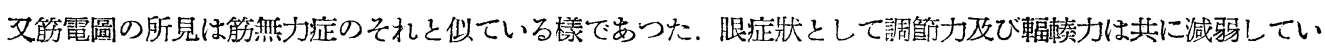
たが監化カリの內服により著しい好轉が認められた.

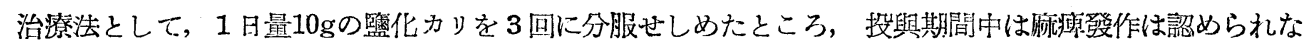
くなつた，次にワゴスチグミンの注射は單罚では無効であつたが，㯺化カリの技與に併用したところ，幾分 かの効果がある樣ですつた。 
35. 肝㙨能障害時に於けるナイトロミンの生體に及ぼす影響について

國立舞鶴病院 角本 永一, 唐澤 浩, 师口 英二

先に「ナ」の家東に及ぼす作用を種々の濃度に於て, 且葉酸, B12を侀用した際の變化を, 赤, 白血球, 網赤血球, 、インッ小體, 中毒性顆粒に就て經過を追つて觀察し, 且䙴殺後の家鬼の藏器組織呼吸並びにそ の血淸の健康動物臟器組織呼吸に及ぼす影響を觀察し報告した. 其の際装酸，B12 は夫及赤血球及び白血球

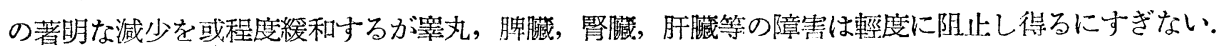

今回「ナ」每 $\mathrm{kg} 5 \mathrm{mg}$ 注射すると同時にメチオニンの大量繁 $\mathrm{kg} 20 \mathrm{mg}$ を投與し，一方あらかじめ種々の藥 物に依り先づ肝臟を障害した家雨に「ナ」が如何に作用するか，且メチオニンがとをどの程度緩和し得るか を觀察した。

赤，白血球の變化はメチオニン投與の如何に拘らず，且肝障害の有無に拘らず 1 逻間後には牛減し「ナ」 單獨投與群之略々同一の減少曲線を示す。

「ナ」單獨投與に依る臟器組織呼吸障宽の程度は等丸，脾臟，肝臟，腎臟，大腦皮質の順であるが，メチ オニン投與により臟器組織呼吸の障害は何孔も輕減され，特に「ナ」單獨投與に依り牛減した睪丸の組織呼 吸は著しく改善される。故に「ナ」投與に際しメチオニンを同時併用する事はその個體の臟器組織呼吸特に 生殖器の障害を輕減するのに役立つと思われる.

36. 自律神經毒に關与る生物學的研究

$$
\begin{aligned}
& \text { 東大物潦內科 北原 静夫, 岩城 榮一, 遠藤 順, 舘野 豊, 谷口弘 } \\
& \text { 橫山朁, 渡邊勝之延, 山積 清一, 土屋 彰 }
\end{aligned}
$$

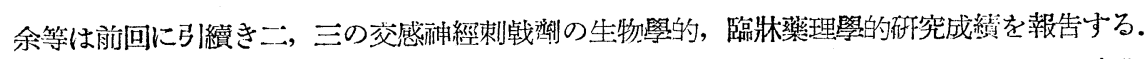

1) 摘出蟇心臟收縮作用については $50 \%$ 收縮量をI-アドレナリンを 1.0 として各種藥物の相對力價を調べ た. その結果dl-N-メチルネオジネフリンには收縮促進作用は認められず，N-メチルエフェドリンはI-歹び $\mathrm{dl}$-エフェドリンに比し收縮促進作用が著しく減弱した。

2） 1-及び dl-エフエドリン，dl-N-メチルエフエドリン各 $40 \mathrm{mg}$ を氣管支喘息患者 5 名に度下注射して

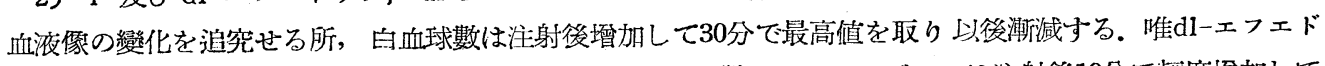
リンは注射後10分で 1 時減少しそれ以後漸增する。好酸球數は1ーエフェドリンは注射後10分で輕度增加して 後減少与るがdl-エフェドリン及びdl-N-メチルエフエドリンは漸次減少する。 ヒンクレマン液による直接算

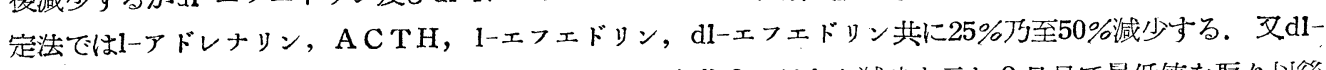
$\mathrm{N}$ ーメチルェフェドリン100万至150mg經口投與では兩者共 6 日目より減少を示し 9 日目で最低值を取り上後 增加する。淋巴球はl一及びdlーエフェドリン，dl-N-メチルエフェドリン皮注射後減少する。

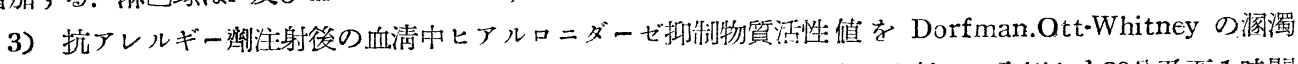
法により健康人 5 名を對照として测定せる所，1ーアドレナリン0.5mg皮下注射では全例とも30分乃至 1 時闘 後に活性值の增大を見た．ACTH10mg敖注も同樣の結果を得た。 1ーエフエドリン40mg度下注射では活性 值の增大を見るが前二者程著しくなく且つその作用時閒は前二者より持續する傾向がある。 d1・エフェドリ ン $40 \mathrm{mg}$ 皮下注射では更にその作用が弱いが作用時間はより持續的である。dl-Nーメチルエフエドリン $40 \mathrm{mg}$ 皮下注射では 4 例中 3 例に輕度の減少があり1例のみ增大寸る。

37. ビタミン $\mathrm{B}_{2}$ 代謝に關する研究（第 2 報）

(ビタミン $\mathrm{B}_{2}$ 燐酸化機轉の解明と之に對する弗素の意義)

$$
\text { 德島大第一內科藤 本 久 雄 }
$$

第1郝に於て慢性弗素中毒症の組織B2含量の牛減せるを知れり。此の)原因を究明寸可く弗素は(1) $\mathrm{B}_{2}$ 自身 


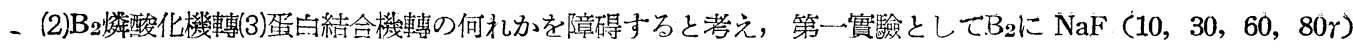
を添加し $37^{\circ} \mathrm{C} 2$ 時間完全遮光の下に作用せしめたるに $\mathrm{pH}=6.4 \sim 6.8$ に於て $\mathrm{B}_{2}(4 \mathrm{mg} \%$ )の湯合丵照本均 $15 \%$

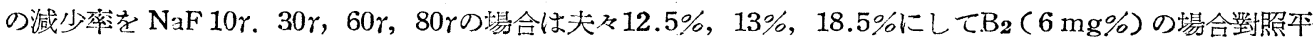
均 $16.7 \%$ に對し夫队 $15 \%, 16.7 \%, 12.5 \% ， 20 \%$ の減少率を示した。第二實驗として $\mathrm{pH}=7.2 \sim 7.8$ に於て

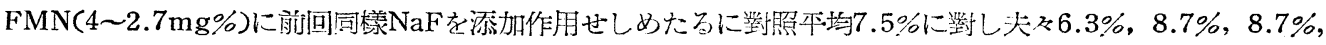

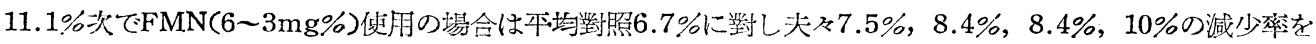

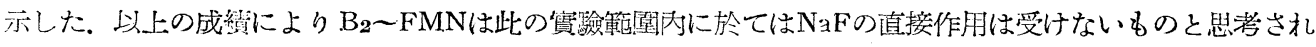
る. 炏でB2憐酸化機轉を解明す可く先つ $\mathrm{Bg}$ の種々な濃度にATPを加え酸性及びアルカリ性に於て $37^{\circ} \mathrm{C} 2$ 時

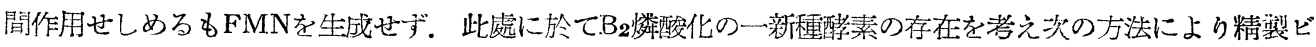

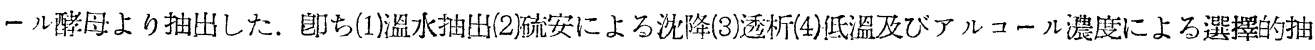
出(5)谏結乾燥. 斯くて得極めて微量の白色粉末醉素は $0{ }^{\circ} \mathrm{C} て ゙ 1$ 溷間以上保存不能の不安定なもので，之を用

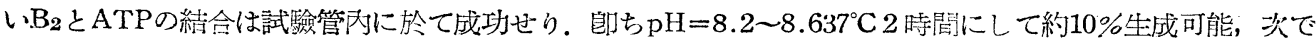

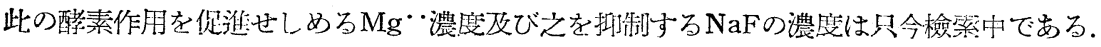

斯くて NaFはB 2 自身に作用するものでなく恐らく燐酸化機轉を障碍するもの〉如く，此の燐酸化は一新 種酵素によるものであり，將來は動物體組織殊に腸壁，肝，緊等より抽出を試みる計畫である。

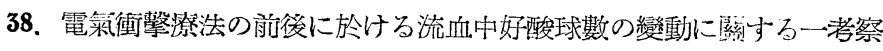

$$
\text { 京府䂑大舘石內科 位 竹義 弘 }
$$

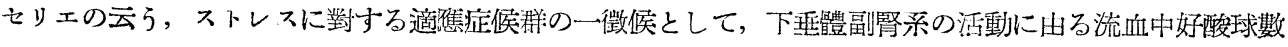
(エ球數)の變動が學げられているが今回, 精神分裂症患者, 其の他に於て, 從來, 其の治潦として行われて いる䉓氣衝擊潦法に於ける流血中，工球數の變動の時間的經過を追跡し，果して衝擊潦法が生體にストレス として作用し，下垂體副腎系の機能に影響を及ぼすか否かを考察して，炏の所見を得たので是に報告する.

檢查方沠，電氣衝擊澺法は現今，精神科に於いての方法を行い，且つ，此較的に $\mathrm{E}$ 球數の日差變動の少い 午爱を選び，檢查中は食慨を攝らせず止むを得ない者に限り，少量の飲水，妿煙を許可したＥ球算定には ヒンケルマン氏液を用い, 衝擊前, 衝擊直後, 直後 1 時間, 3 時間, 4 時間に互つた.

檢查成賏，精神分裂症㭧者に於いて，電擊潦法のみ施行した例(22例)では，最大減少時間は，平均衝軗後

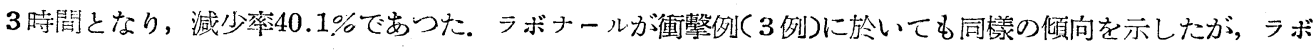

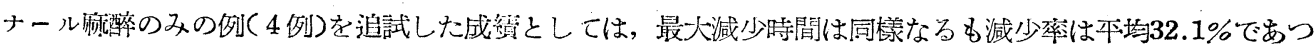
た。神經衰弱症に於いて，同樣檢查を施行した處，衝擊の久の例では減少率は本均 $45.0 \%$ ，ラボナール加衝 䌘例では46\%であつた。

上記の成續より，電氣衝擊潦法は生體にストレスとして作月し，下互體副腎采の機能に多少とも影響を及

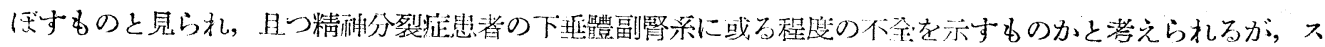
トレスとしては，複称な內的，外的目子が包含されるので，今後更に種々の面より，檢討されるべきわのと 考えられる。

39. 䟚液腺ホルモンの研究（第28報）パロチンの物理化學的性質 (2)

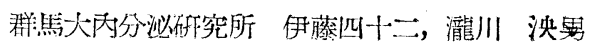

昨年度の本緦會に於て，パロチンの物理化學的湘定法について報告したが，今回その方法によりパロチン の熱及び酸アアルカリに對する性質を估究し，また分光學的な澌定を行う場合に紫外線或は赤外線の照射に より.變性を受けるや否やについて吟味した。

試料は硫安濃度20\%で析出したパロチンの1\%溶淮を濑同した。

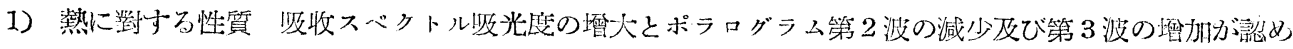


られた。牛波電位は變化しない。

2）酸に對する性質 吸收スー゙クトル，ポーラログラム共に變化を認めない。酸性では安定である。

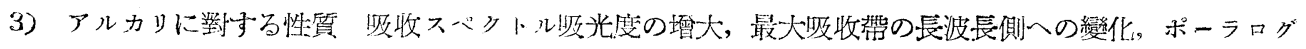
ラム第2 波の墰大，生波電位の十方向への移動が認められた。アルカ性では分解され易い。

4）紫外線照射による影響 90 分以內には物理化學的性質及び生物學的作朋の變化は認められない。

5）赤外線照射による影響 90分間照射により物理化學的性質は變化するが生物學的作用には，著しい變 化は認められない。

パロチン溶液は酸性及び中性では變化しないが，アルカリ性では 48 時間上後は分解される，40ㄷ，24時間

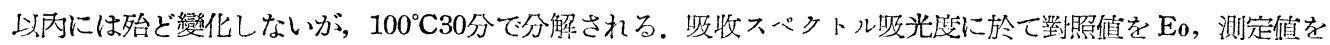
$\mathrm{E}$ とし，ボーラログラム第 2 波の波高を $\mathrm{h}_{2}$, 第 3 波の波高を $\mathrm{h}_{3}$ とす扎ば， $\mathrm{E}_{0} / \mathrm{E}$ 及び $\mathrm{h}_{2} / \mathrm{h}_{3}$ により分解の狀 態を測定することが出來る。

40。睡液脉ホルモンに閵ナる臨床的並びに實驗的研究（續報）

柬大田坂內科 田坂 定孝, 高谷 治, 福鳥 秀夫, 石井 策央, 山叮學 友野 隆, 官野 重長, 內藤 周幸, 小田 正幸, 岩岡 順 六城 雅彙, 佐藤 智, 樺澤 泰一

パロチン(唾夜腺ホルモン)に就いて引續き各種生物學的反㗹，病態生理學的反㗹を中心にして檢䇣を進め た.

（1）パロチンの作用機序に就いての研究を家鬼に於いて實騟的に行い，同劑の視床下部內注入等の處置に より，パロチンの多くの生體反篧は間腦を經由して開發される面を有する事を認めた。

（2）パロチン一定量投與により一般に動物は輕微な發熱を示すが，幼若ラッテに連日發熱量のパロチンを 投與しても，その體重增加曲線に著明な影鄉を認めない。

(3) ラッテに發熱量のパロチンを投與し肝臟の核酸及び燐代謝に及ぼす影響を檢するに，その交替菜汇著 變を認めなかつた。

（4）前報に引續き血液疾腎に對するパロチン投與の臨床例を 7 例追加し，ナィトロミン使用によろ自血球 減少症 1 例, 血少板減少性紫斑病 1 例に効果を認めた。

(5) 人體に於いて，パロチン投與はプロトロンビン時を短縮せしめ，出血時間不變睹液凝固時間は短縮せ レめ, 血少板數を增加させる. 又フイブリノリージス陽性化, アンチフイブリノリージス陰性不變の傾向在 認めたが，これ等の作用は生體反應を介して現わされるものと考えられる.

（6）雌性鴔に於けるコレステロール食による實騟的動脈硬化症發生に及ぼすパロチン投與の影響は，パロ チンの各種投與量に對し常に血中總コレステロール值主び燐脂質傎, 增加の傾向を示し, コレステロール食 による動脈硬化發生を抑止。し得奴傾向を示した。

41. パロチンの作用機轉

東大沖中內科 山田 信輝，石川 俊之，高岡 善人

パロチンを注射した際。血中アミノ窒素及び殘餘窒素が低下し，同時に尿中への窒素及びクレアチンの排 洲が抑制される事等から，パロチンが蛋白代謝に影響を與える事を赧告して來た。

今回更に，アミノ酸溶液であるポリタミンを經口投與した際，パロチンが血中アミノ窒素並びに尿素窒素 の變動に及ぼす影響，及びパロチンが肝核酸燐の turnover に如何なる影響を與えるかを檢討した. 倚前者 には約 $250 \mathrm{~g}$ の雄性的鼠，笋者には約100gの雌性白鼠を便用した。

1,ポリタミンを負何した際血中アミノ窒素に及代すパロチンの影響 (1)舤處置の白鼠にポりタミンを負 荷した際, 30分乃至 1 時間にて血中アミノ窒素は最高となり上後下降す. (2)パロチン $4 \mathrm{mg} / \mathrm{kg}$ 注射して 4 時 


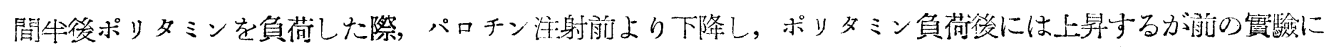
比しその上昇が低い。

2.ポリタミンを負荷した際血中尿素窒素に及ぼすパロチンの影響 (1)無處置の白鼠にポリタミンを負荷 した際，1〜1.5時間で血中尿素窒素は最高となる。(實驗㷙值に比し $28 \%$ 上昇). (2)パロチンを $4 \mathrm{mg} / \mathrm{kg}$ 注: 射して 4 時間牛後ポリタミンを負荷した際，パロチン注射前より約10\%下降し，ポリタミン負街後には最高 值は1.5〜2時間と移動し, 且上昇䒺は $14 \%$ で前の實驗に比し低い。

3. 肝核酸橉代謝回轉に對するパロチンの影響 パロチン $1 \mathrm{mg} / \mathrm{kg}$ 皮下注:射した際の $\mathrm{P}^{32}$ による肝

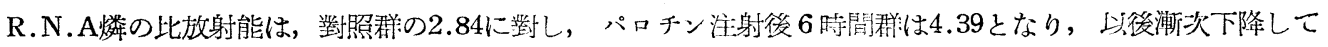
24時間群:では殆しど蕉值に復した。

\section{追加}

東大田坂內科 織 田 敏 次

只今の御講演中に私どもの實驗成䋹について衔引用がありましたので，一言迫加させていただきます，パ ロチンを 1 涸間連續投與して. $\mathrm{P}^{32}$ 投與後 24 時間目に屠殺して檢查し，その後またパロチン投與後 6 時間目 の成續をも迫加して檢查致しましたが，肝臟の核酸代謝にはみるべき變化をみとめませんでした．そのほか， たとえば Methylandrostendiol はP $\mathrm{P}^{32}$ を投與して42時間に, R N A-P の艾替率は慬かながら, 約 10\%の 上䒜をみる。この場合でも， $\mathrm{P}^{32}$ 投與後 3 時間に測定したのでは，有意な差をみとめることができない，ま

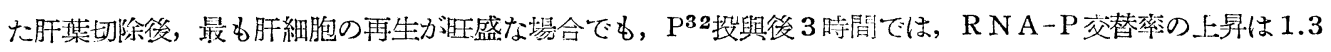
倍を示すにすぎない。DNA-Pの艾替率はすでに，4×に增加する。

42. パロチンと蛋白代謝

$$
\begin{aligned}
& \text { 慶大食養研究所 原實, 河野 黎子 }
\end{aligned}
$$

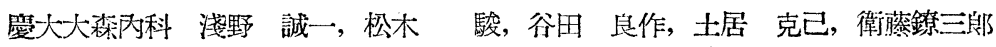

$$
\begin{aligned}
& \text { 加藤 暎一, 小島嘉三郳, 柴田 貢, 國分 豊明 }
\end{aligned}
$$

從來の動物實驗並びに臨床實驗ではパロチンに盆白蓄積作用を思わせる結果が報告されているが，吾ふは 之を健康成年男子に用いてパロチンの蛋白代㛛に及ぼす影響を研究した。被驗者は健康成年男子 3 名で食餌 を一定として熱量出納のパランスを過不足無き樣にし，蛋白質攝取量を體重 $1 \mathrm{~kg}$ 當り $1.3 \mathrm{~g} と し ，$ 尿量を一 完とならしめる焉に即水量を 1 立, 攝取食監量は食品中を合せて $13.5 \mathrm{~g}$ と定めた，パロヂンは 1 日 $10 \mathrm{mg}$ 宛 1 週間注:射し, 其の前後1週間宛と㴊せて3週間について, 窒素出紟・血液蛋白・水代謝・尿中17-Ketosteroid 等を測定した。

吾々の得太結果では明らかな蛋白蓄積作用は認められなかつたが，被匳者個々の例について檢討寸ると， 最もよく效いたと思われる例に僅か乍ら窒素出納が正の值を示した事, 負の出編を示した例ではその原因を

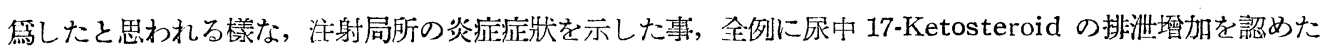
事等を考之合せる時, 注射量の墰量・副作用の除去によりパロチンによる歪白蓄積作用の可能性が推測され た.

43. 䡖液腺剔出の血淸アルカリフォスフアターゼに及ぼす影響

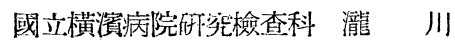
頨

實驗目的 唾液腺內分泌は燐代謝に何等加の鬥連性を有寸るものではないかと考えられる。此の點に關し， 千大传及木氏はパロチンに依り骨端フォスファターゼが唒加する傾向があるとして居り, 東大高岡氏は臨床 上血淸フォスフアターゼの上杽した例を認めて居るが其他の諸家の郝告は必ずしも之と一致した成緯を示し て居ない，此の點を特に追究しようとして，動物實驗を試みた。

實驗成悢 6 頭の家鬼の棰液腺を剔出し, 之をなるべく一定の條件の下に飼育し, その血清アルカリフオ 


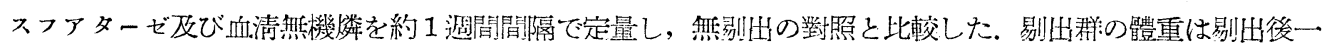
時的に減少するが術後 1 涸間以後は對照に劣らず墰加して属る，但し體重の增加しないものが 2 頭もつたが 之は30日後及び80日後に死亡した。

血淸アルカリフォスファターゼは對照家雨でも相當上下はするが約 5 ケ月間の觀察期間中特に上昇又は下 降の傾向は示して扂ない，之に對し剔出群は徐々に下降の傾向を示し，約 3 ヶ月後には術前の約牛量に，4

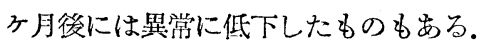

血清焎機燐量も同樣に徐々に低下して居るが，對照家鬼では著變を見なからた。

別に 4 頭の唾液腺剔出家鬼に就き，その內 2 頭に術後40日間每日1.5mgのパロチンを連續皮下注射した。 實驗期間が短く，且例數が少いため眀膫な所晃を得なかつたが，傾向としては，パロチン注射期間中或る程 度血清フ及び血清無機燐の低下が阻止されて属る樣に思われる。

44. パロチンのアレルギー疾患に及寸効果並にその血清學的矿究

桼大美甘內科 栗本 東一, 監川 優一

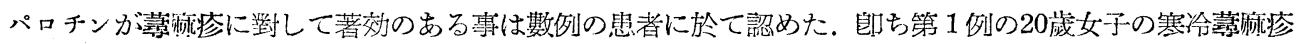

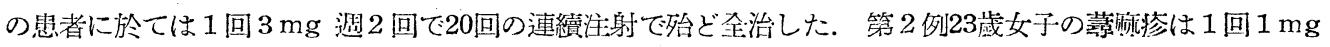
涸 2 回で殆ど輕快した。第 3 例 29 歲の女子は彷回 $1 \mathrm{mg}$ 囷 2 回で30回の注射を行つた處始めは仲及治らずレ スタミン等を作用したが 3 回目からはパロチンのみで治滰し終に全く出なくなつた。第 4 例は38歲の男子で 1 回 $1 \mathrm{mg}$ 注射のみで治つた. 第 5 例は47歲男子で難症であらゆる省劑を用いて治らなかつたものが $5 \mathrm{mg} 1$

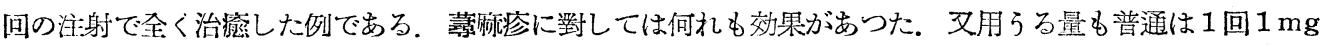

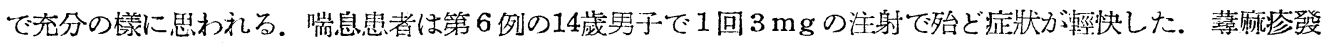
現を抑制するためには補體を減少せしめるか，抗體產生を抑淛するか或は其の他によるるのである．第1の

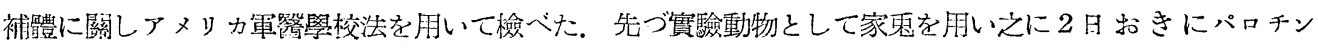
$1 \mathrm{mg}$ 注射した注:射前注射後 3 日目及び 6 日目の補體價は何れも 0.05 で變化なく臨床實騟では皮膚炎高血捱

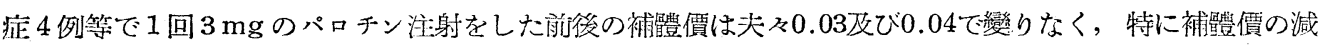

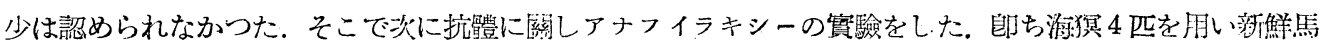

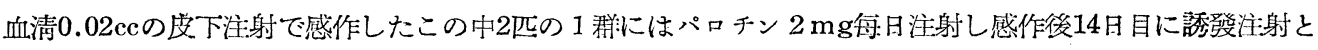
して同じ馬血清 $0.1 \mathrm{cc}$ を项静胍に注入した所パロチン注射群の中 1 匹は注射後多少目をむき不安氣に步くも 生存他の 1 匹は注射後あばれ 6 分で死しパロチン注射をしない群では 1 匹は目をむき叫び 3 分後苦しがりは ね 5 分後呼吸停止 10 分で死亡他の 1 匹は目をむき叫び鼻をこすり元氣なきも生存, 之で各洋とも何れもショ ックを起し實驗, 對照群とも1例死亡生存で特に抗體堂:生を抑䦌したとは云えない勿詇少數列であり之で云 ふ寸る事は出來ないが他の要素によるものではなかろうかと考える.

45. 唾液腺ホルモンの甲狀腺機能に及ぼす影響

國立東京第二病院內科 倉 光 一 郳

覀液腺ホルモンが甲狀腺の I ${ }^{131}$ 攝取菜にどのような變化を與え, 又この變化が從來知られている甲狀腺 作用物質と，どのような相暴或は相似を示すかを追究してみた。

方法 $100 \mathrm{~g}$ 前後の白鼠を朋い，各群共對照をとり， $\mathrm{I}^{131}$ は $5 \times 10^{5}$ counts 前後を尾素脈より注射，その 後24時間で屠殺, 所要臟器を直ちに科量, 一部を放射能計測, 他部を組織像, Radioautograph 用とした。

結果 〔1] 過唾液腺症, 無睡液腺症の術後50日のものでは甲狀腺の $I^{131}$ 攝取交對照に最も多く, 過唾液

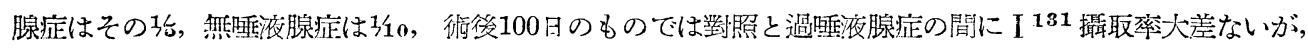

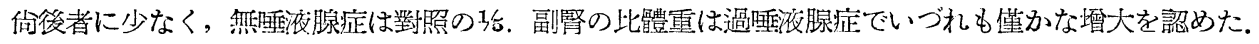

〔2] Parotin $3 \mathrm{mg} / \mathrm{kg}, 20 \mathrm{mg} / \mathrm{kg}$ を 4 溷間ほが隔日に皮注 $3 \mathrm{mg} / \mathrm{kg}$ 注射群は體重增加率最も大，甲狀腺 


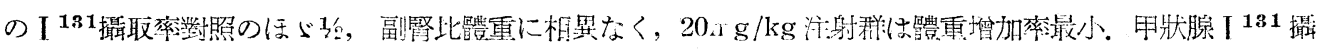

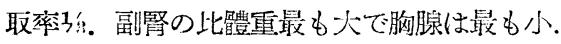

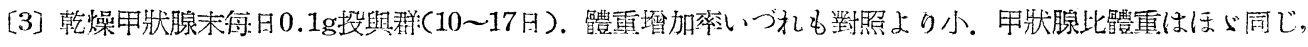

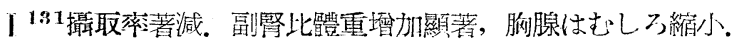

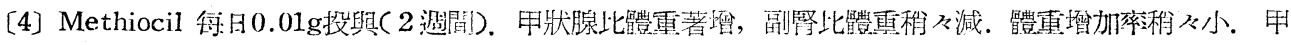
狀腺の I ${ }^{131}$ 攝取萗ほ心゙對照の16であつた。

[5] A C T H0.5mg (A) : Protin 2mg/kg (B) を舴日注射し 12 日間, A C TH $2 \mathrm{mg}$ (A') : Parotin

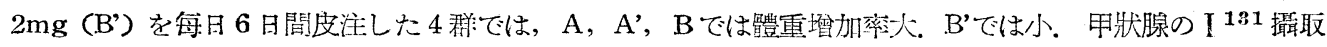

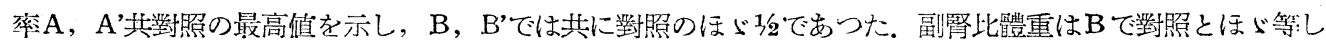

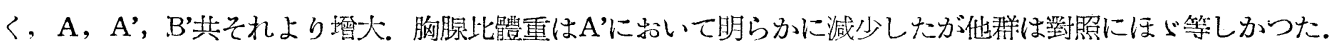

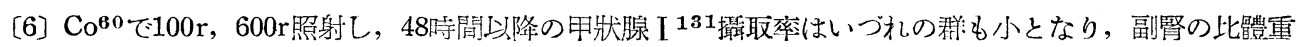
恓加を見るが照射後時間の絰過と共に甲狀腺の $\mathrm{I}^{131}$ 攝取率は急速に恢復して正常に近づく.

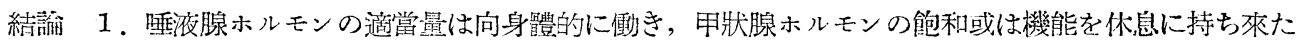
すものと推察される。

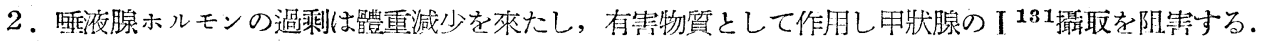

3、垂液腺ホルモンの缺如は發有を阴害し，これに伴万甲狀腺の機能低下を認める。上の事唡は又組織 學的所見とも一致している。

46. パロチンの二十日鼠レントゲン照射に及寸影響に就て

東大美甘內科 鿄 本 束一

ニ十日鼠に300〜600レントゲンのレントゲン照射を行つた垬合動物は速かに體重減少し㱜亡する事，この 祭肝葳及び睪丸が强く犯されるものである事等も知られている。處が1952年 Patt はニ十日鼠にレントゲン 照射を行う場合をらかじめ Cysteine の一定量を注射した塂合には生存期間を延長させ，レントゲン線の効

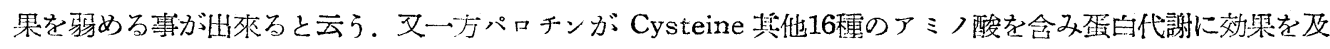

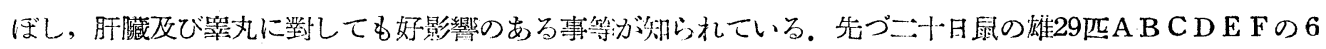
啡に分ち A B C の啸洊は每日 0.2mgのパロチンを注射しC D Eには注射せず，レントゲン照射は最初 1 回 A Dには各600レントゲン B E には备300レントゲンの照射を行つた處照射後12日目の生存數はAは 6 中 $2 \mathrm{~B}$ は 5 月 $4 \mathrm{C}$ は 2 中 $2 \mathrm{D}$ は 6 中 $1 \mathrm{E}$ は 7 中 $3 \mathrm{~F}$ は 3 中 3 となり, 多少の差をパロチン注射群としない群に認め た。次に本均體重の變化は生存したものについては著明な變化は認められない. 次に 32 日目に潟血後死せし

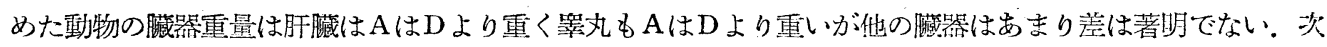

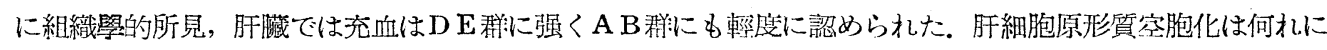
も認められたが，殊に A C F で强い，肝細胞核の仁小體はA BCに認められるも，DEに多く Mobilisation

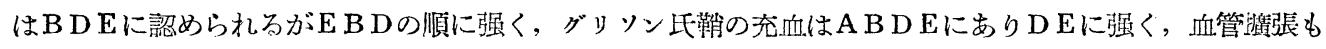
A B Dに於て中等展に認められた，面に睪丸に於ては何れも精娘細胞汽の形成にはあまり變りないが，精子 はA B D Eに少く列にDEには全くない。次に染色性はA B C 郡に於てよく退行變性，萎縮性變化はD Eに 强度である。郎ち之汽に述べた事からパロチンが二十日鼠のレントゲン照射に對して多少とも抑垁的作用の ある事を示するのと思わ机る。

冎レントグン照射は東大放射線科杉村氏艺行つた。

47. 高血緊症に對するパロチンの使用

名大分院內科 山田 弘三，岡部一利，山田 香苗

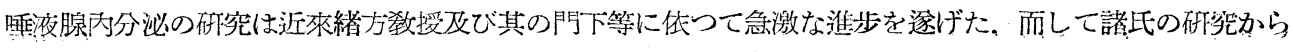




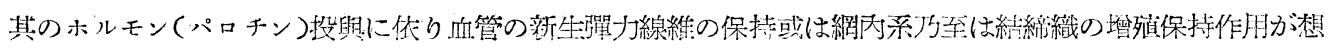

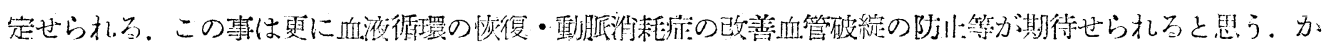

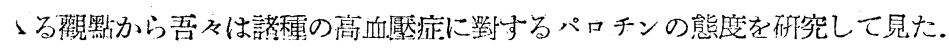

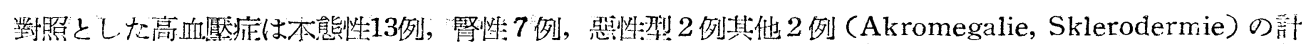

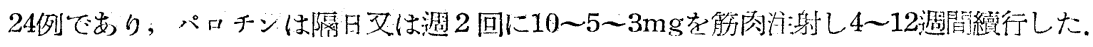

實噞成結

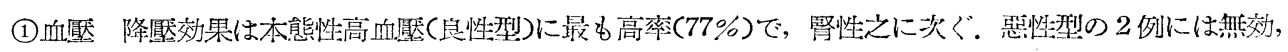
全例平均 $62.5 \%$ に効果在認め最も㙷著なものは收縮期邆 $80 \mathrm{~mm}$ の低下を認めたものもあるが通常 $30 \sim 40 \mathrm{~mm}$

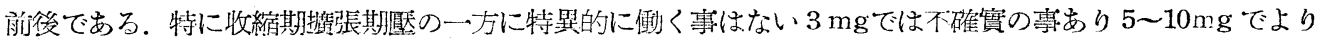
有効である.

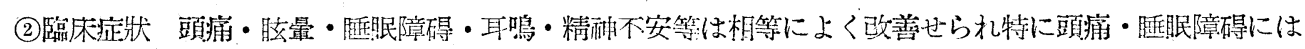

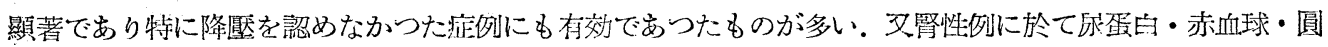
杜・上皮細胞等沱渣の改善を見たものが若干ある。

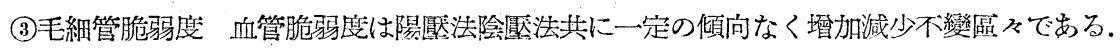

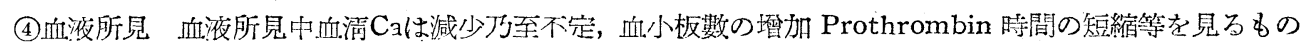

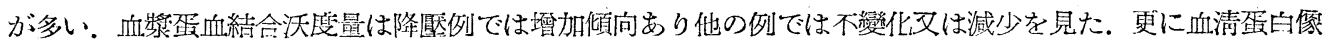
は總蛋白量の減少の外著變なく特殊の 2 例に $\gamma$-Globulin の低下を認めた。

以上の如く高血是症に對するパロチンの使用は作用機序其の他に疑㫮も多く更に檢討を要するが或程度の 希望を持てるものと考える。

\section{追加} 三樂病院 栗 本 束 一

私はパロチンの高血厴症に効むる事を昨年の學會で追加した，現在三樂病院に於て高血厴急性腎炎等に試

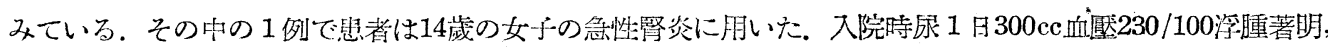

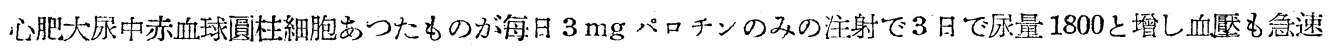

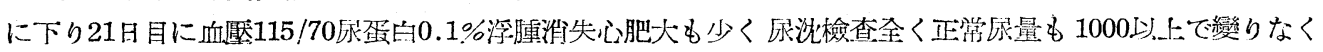
全く元氣になつた．此樣に急性腎炎に對しても効のあるものと思われるので追加した。

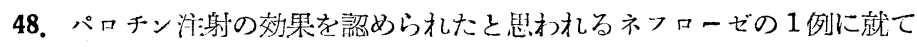

身大美甘內科: 梁本 乘一, 長田 昌明, 辻 照雄

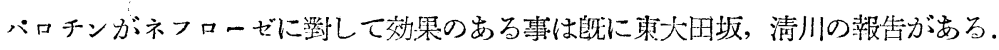

清川は1例の小兒科ネフローゼて数回のパロチン1涸間注射漝法の後尿量增加及び尿中蛋白の沙失まで招 來にたと云う患者は27歲男子で既往歷としては 17 歲に左 20 歲に右の肋膜炎を患いWa-R反隹陽性と云われ治 潦をらけた他には特記すへきものなく, 家族歷としても特記すべきものはない. 現症, 1昨年12月顏がもく んだので醫師の診察をうけた處血熙高くなく，尿に赤血球なく，しかも尿に蛋白が多いのでネフローゼと云 われたと云う，入院時體格上く著明な症狀としては蛋白尿浮腫, 腹水し濁害界の增大等であつた。治潦とし て昨年12月11日から每日パロチン $5 \mathrm{mg}$ の注射を試みた處注射前は㽷量100〜600比電 1026〜 1037，尿蛋白 $17 \%$ 。體重 $56 \mathrm{~kg}$ であつたものが注射開始公 4 回目で尿量1000比重1014，尿蛋白 $5 \%$ 體重 $60 \mathrm{~kg}$ となり 更に注 射 9 回目には泉量 3350 , 此重 1008 , 庣蛋白 $0.5 \%$, 體重も減少し始め, 11 回目からパロチンの 1 回量を $3 \mathrm{mg}$

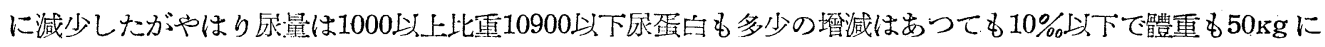
減少し息者の浮腫も消失し全く元氮になつた，注射14回で中止後 5 日目から再び尿量の減少，此重の增加，

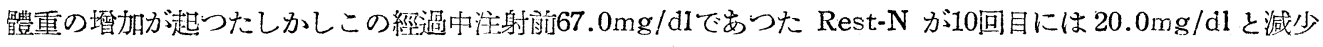
し，血清C、は清川は買加すると云うが此場合も7.12から8.13に增加し，血清蛋白も4.5から6.8に增加して 


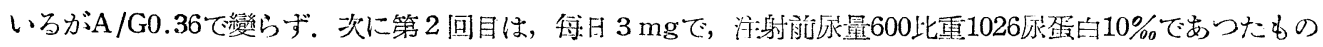
が注射翌日から㕄蛋白 $8 \%$ となつた。しかし10日目には再び尿量減少し始めて 3 回目は $5 \mathrm{mg}$ で 3 日後には 尿量2700比重1006となつた。しかし㕄量の減少は次第に起つて來た 此榜に注射開始後間もなく利尿效果の あらわれた事及び淮射打きり数日後に辰量の最大值に達した事は注目すべきものである。此樣に次第に「パ」

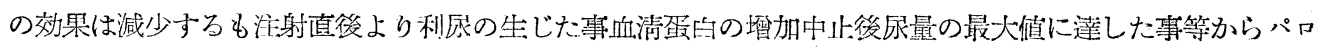
チンの効果々栲える炏第である。

49. 量症筋無力症に對山当 Parotin の治泳効果に就いて

東大冲中內科 高岡 善人, 吉川 政己, 宇尾野公義

重症筋眎力症に對しては抗ChE劑，ビタミン，畉胞ホルモン，KClなどが用いられているが，私共は最近

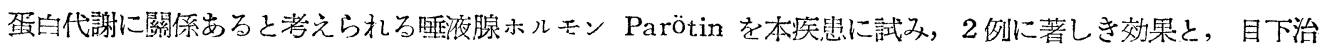

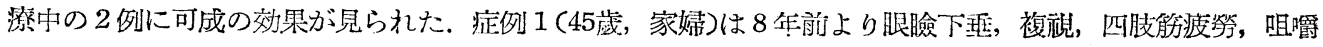
力低下, 發語及び呼吸障㥂を生じ Vagostigmin で改善せられる典型的重症筋奥力症であるが, Parotin 1

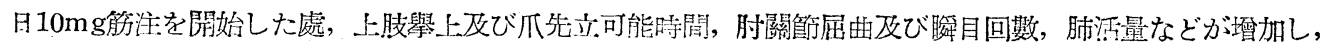

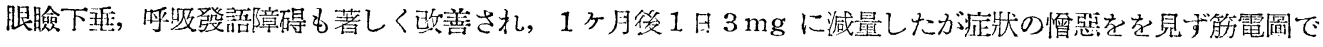

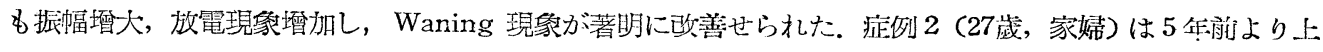

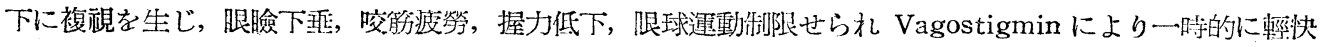

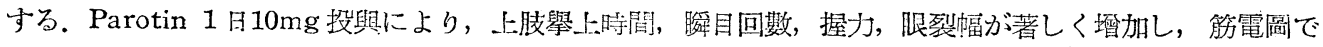

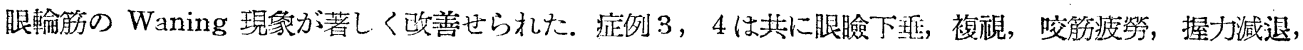
四肢筋脫力を主とし，Vagostigmin 上外の潶法で効果を示さなかつたが Parotin 閉始以來前記症例の 如

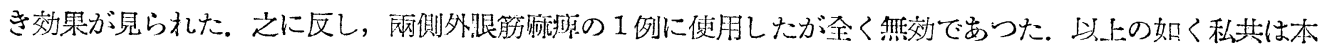
症に對し，Parotin が抗ChE劑その他ホルモンなどと別個の價值あるを見出した．然して本症の本態として Ach代謝異常剆ちAch生成の低下，ChEの過剩，筋終板の興奮性低下などによる Myoneural junction の 障碍が最も重要視されているが，Parotinはもしろ血清ChEを增加せしむるものである，從つてその効果の

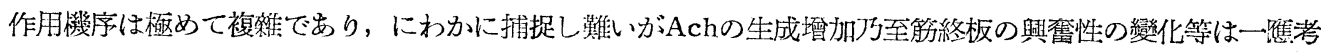
慮さるべきであろう.

50. Hurler 症候群と Parotin

名大日比野內科 飯田 英男, 䳑野 昌夫, 青木 國雄

本症候粕は我國に於てなお數例の報告をみるのみであるが，我及は最近經驗した症例について各種㙨能檢 查を行うと共に Parotin を投與して經過を觀察した。

患者は12歲の女子, 遺僡的器係は明かでない，大頭症・鞍鼻・互舌・厚唇・短肢症・同長指・0 脚等典型 的な外見を呈し，骨のレントゲン所見も Epiphyse に於ける發育障碍が眀かである。肝臟機能檢查成絟は 血清高田反㗹(一)であつたがブロムサルファレイン試驗では45分後に於てなお $15 \%$ 血清色素量を示し, 肝 脾腫大も明かにみとめられた。角膜洞濁はみとめなかつたが精神發育はシェクスラーの子供用知能診斷テス

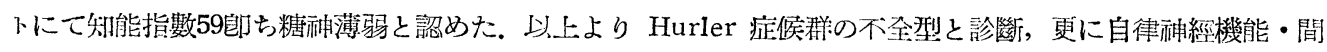
腦一下开謴副腎柔機能々の他內分泌學的諸檢查を行い，何れも異常をみとめた。

本症候郡肪 Chondrodystrophia foetalis と極めて類似与ることから Parotin の投與を行つた，即ち第

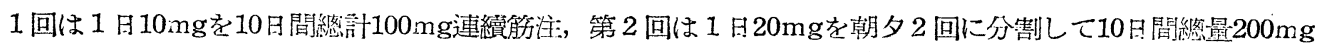

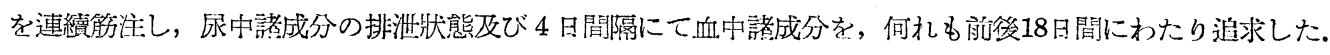
その結果, 尿中 Creatinine の排泄㮎加, Creatine の減少, 總燐量の減少, 17-Ketosteroid の增加をみた。 總窒素、尿酸，Clは一定の傾向がみられなからた，血液成分では残餘窒素の減少が最も著明で血清Ca，血糖， 
血液Clの低下もみられたがMgはわずかに減少傾向があるのみで，無機燐尔び Cholesterol は一定の傾向が みられなかつた，血漿蛋白俉は Parotin 投與の前後に於て殆ど變化がなかつた。

一方臨床的症候立びに骨のレントゲン像には何等の變化をるみとめえなかつたが，上記の Metabolic

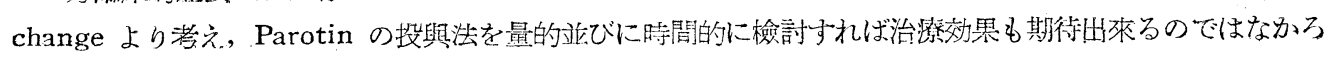
らか.

51. 甲狀腺機能艺進の肝欌に及ぼす影響

京大井上內科 芷上 硬, 藤田 輝雄, 市田 交弘 田代 扶, 小池 㻤藏, 松永木見子

最近當科に入院した甲狀腺機能立進症の22例に就いて臨床所見, 並びに基礎代謝率と肝機能との關係を檢

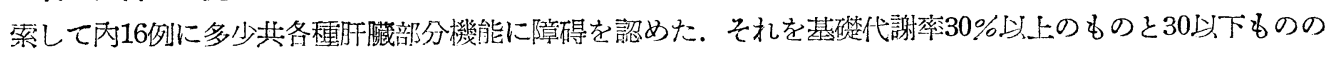

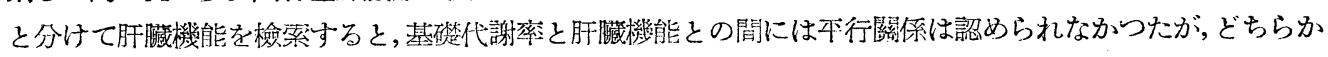

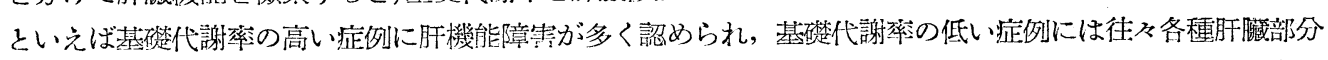
㙨能殊に實質細胞障碍に起因寸ると考えられる「コ」エステル比率，果糖虎理能がー過性に正常以上に古進 を示す症例を認めた。次に甚礎代謝菜30\%以上の 9 例のちち 3 例に就いて Biopsy を行つた結果コベルト 反應6.7を示した例には程度の美はあれ間質結合織の增殖を認め，1例に於いては續發性肝硬變を思わせる 變化を認めた。更に1例にはその本態は不明であるが可成りつよい小圓形細胞浸潤と小葉內に格子狀䋐維の

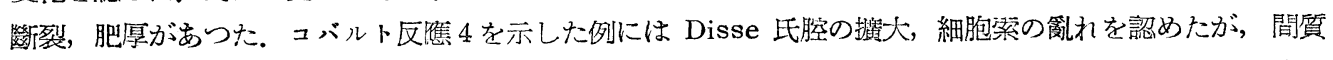
結合織の增殖はなかつた。

\section{追加 啠問}

丸田公雄

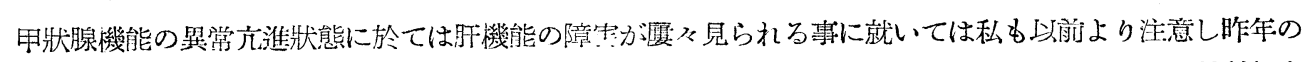

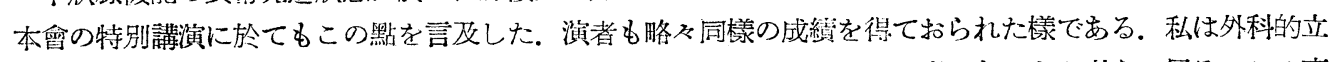
場からこの肝機能障害と副腎の機能障害とが術後バセドゥ反㗹の重要な要素であろうと考えて居る.この事 は㸚窒の浦野等の動物實驗成綂からも明らかに看取出來る。その詳細に就いて改めて發卦する。

52. バセドウ氏病に於ける肝機能

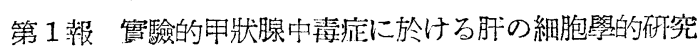

$$
\text { 信州大丸田外科浦野晃, 岩崎哲, 大野幸蒝 }
$$

バセドウ氏病に於ける肝機能障碍が術後バセドゥ反㗹發生に對する有力な一因子である事は, 堂て丸田敎 授の垠告した所である，その後吾及が行つた主として蛋白代謝に基く肝機能檢查の成紹に於いても同樣の事 實を認めている。吾ぬは此の事實を更に詳細に迫求する窎に，先ず第一段階として犬及び海猽を健用した動 物䁈驗に於て甲狀腺荝の撖與前後に於ける肝細胞の變化，特に系粒體及び糖原含有量に就いて病理組織學的 研究を行つた，その結果，バセドウ氏病に於ける肝機能障碍の病理發生機序に就いて一新知見を迫加し得た そ信ずるので，その成續を報告する。.

病現組織學的檢索法として, Haematoxylin-Eosin 染色, Sudan $\mathbb{I I}$ 染色, Heidenhain 氏鐵 Haemato xylin 染色, Altmann Kull染色, 溫沃度酸法, 及び Bauer 比法を行い, 更に棰液消化試驗む併せ行つた。 その成結は次の通りである。

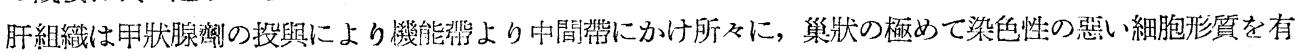
する部分が出現し，一部のものでは中心性脂肪沈着と藷明な空胞變性に陷つた部分を認めた。次に糖原は投

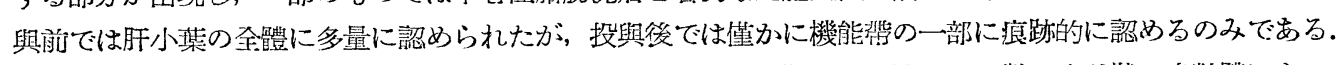
又糸粒體染色の所見では，投與前に於ては全般的に多數の細糸狀の糸粒體と，少數の小球狀の糸粒體によつ 
て占められ，少數の分汹顆粒を認めるに過ぎないが，投與後では糸粒體は一般に太い悍椥狀となり，而も网 端の澎大せるもの，曲王狀のもの，球狀或は連珠狀のもの等も多く見られ，更に所々に分泌顆粒，洨化傾向 を示与輸狀顆粒及び染色性の稀满となつた分泌颗粒が認められた。

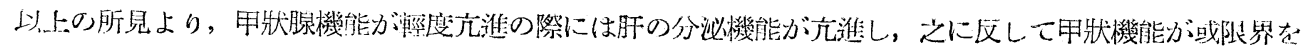

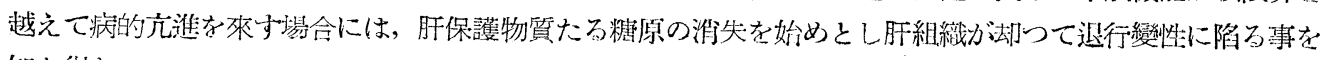
知り得た.

53，甲狀腺の機能異常に基く副腎皮質變化の組織化學的不快究（第 1 報）

$$
\begin{gathered}
\text { 信州大丸田外科 太田 庄司, 降旗 力男 } \\
\text { 信州大病理 矢川 寬 - }
\end{gathered}
$$

バセドウ氏病及び甲狀腺中毒症に於いては副腎皮質の機能暴常が尠からず認められる事實から，演者等は 家鬼を用いて實驗的甲狀腺中毒症を發生せしめ，その際の副腎皮質變化に就て組織化學的研究を行つた.

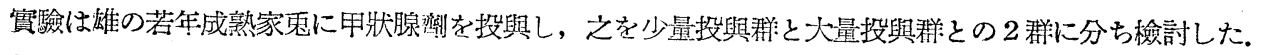

組織化學的檢索法としては, Sudan III 染色 Schiff 氏 Plasmal 反磼. Smith-Dietlich 氏 Lipoid 染 色, Schulze 氏 Cholesterin 反㗹を行い，佾 Haematoxylin 染色も行い檢討を試みた。

その成綪を總括すると，甲狀腺濟投與による副腎皮質の主なる變化は，全例を通じて見られる索狀層の肥 厚に基く皮質の增大及び Sudan II染色立びに其の他諸反應の沙失乃至陰性化であつて，更に大量に長期間

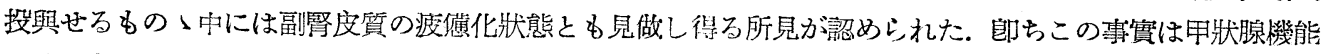
と副腎皮質との間には密接な關係のあることを示するのであつて, 甲狀腺中瑇症狀が長期間に亘つて高度に 續く合には，副腎度質は疲僙化狀熊に陷るものと考えられる。

54. 岐阜縣下の甲狀腺睡に就て（第 2 赫）

岐皁縣立大學內科 三宅 儀, 吉田 收, 井户 豊彥, 小野一期

私達は岥皋縣下の甲狀腺腫に就て調查を行つているが，第 1 郝に續いてさらに郡上，加茂兩郡の夫を㫕了 し. 益田其の他の諸市郡に就ても調查を淮めたので報告致します。

調 查方 法

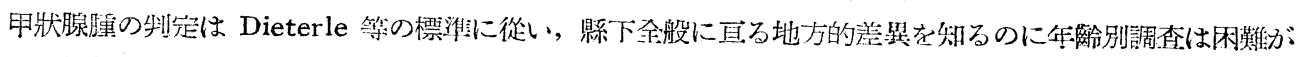

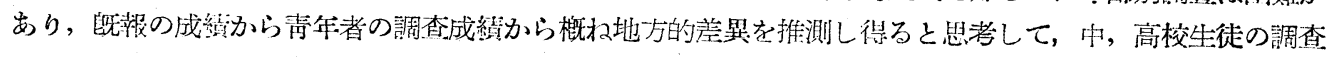
のみを行つた。

調查成紅鿌系上部は殆ど全町村の中, 高校生徒合計男子 2248 多, 女子 2010 名の調查を行い, 內甲狀腺腫者數

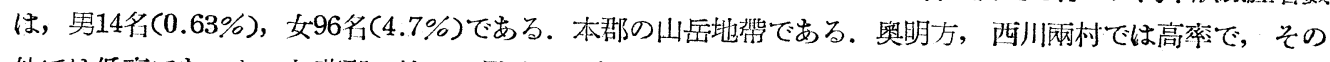
他では低菜であつた，加茂郡に於ては男子2092名，女子2079名を調查しその甲狀腺腫者數は男 $10(0.48 \%)$, 女66(3.2\%)で，本郡では地勢と甲狀腺腫碎の關係は明らかでなかつた。

益田郡の大坐と，その他の市，郡の一部中，高校に就いても調查を行つた。

考按

各市郡共に甲狀腺腫は 2 度のものが大部分であり, 3 度の甲狀腺腫は郡上郡 2 名, 加茂郡, 武儀郡に备 1 名でいずれも女子であつた．郡上郡では地禁の高低による甲狀腺腫率の差埋が認められたがその他の地方で はそれ程明らかでない。

綘詇

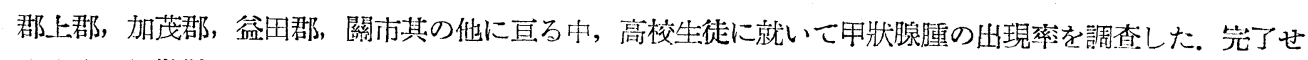
ろ郡上郡の甲狀腺腫䒺は男 $0.63 \% ， 女 4.7 \%$ であり，加茂郡に於ては男 $0.48 \% ， 女 3.2 \%$ であつた．其の他益 円郡の大牛, 關, 武儀, 山縣旸, 島稻藮の諸市郡の調查をも行つた。 
55. 中请性甲狀腺腫患者の運動負荷, 及びACTHの影響について

大阪市大小田內科 小田 俊郎, 藤田 榮一, 行友 正裕, 藤田 惠三 河南清八斯, 川口 自由, 松本 恒男

中毒性甲狀腺腫が，運動負荷，及び ACTH に如何に反㗹与るかを知る䉆に，好酸球，尿17K.S. 血糖，心

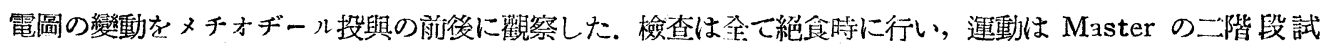

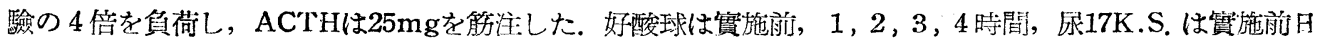

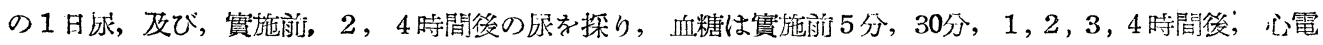

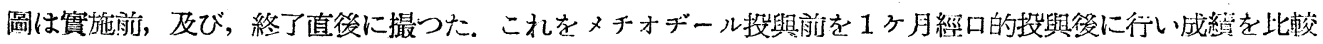
した. (1)好酸球, (A)運動 : 17例に於て減少傾向が各及異り, 最低值が 3 時間のbのと 4 時閆のものとがあ り，最低下のものは 4 時間後 $46 \%$ までである、メチオデール投與後は概して前より減少萃の高いわのが多い. (B) ACTH 筋注は $50 \%$ 以上減少 2 例で，メチオデール投與後に 8 例を認めた. 又運動と ACTHに對する好 酸球减少態度は，ほぼ平行する事を認めた。(2)尿17K.S.メチオヂール投與前後の1日量は殆んど正常範園 であるが，投與後は13例中 8 例に前より墰加し，投與前平均7.941 mg/day投與後平均 $9.762 \mathrm{mg} / \mathrm{day}$ である

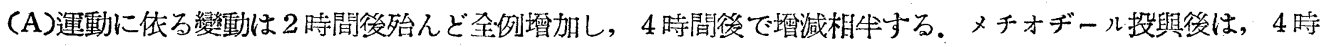
間後の減少するものが少くなる. (B)ACTH筋注も運動と同じ變動するが，4時間後の減少が少く，メチオ

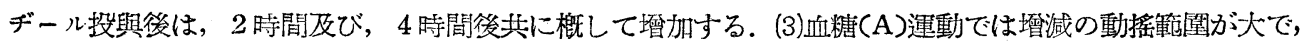
時間と共に減少するものが多く, メチオデール投與後は動摇範閔が狄く, 減少するものが少い. (B)ACTH

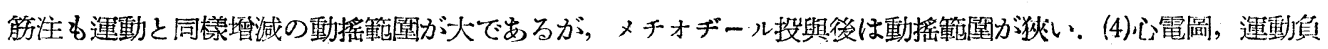
徛によつて，ST.Tの低下を示するのが多いが，メチオヂール投璵に依り改善された。

56. 甲狀腺機能立淮症の好睃球の變動に就て

東大田坂內科 本 野 非 值 英

昨年本學會に於て甲狀腺機能立進症の $\mathrm{ACTH}$ に上る好酸球の反礁態度に就いて健康人上りその減少菜の 著しく高いことを郝告したがその笋の成續に就いても前回同樣であつた. 次に本疾患に於ては發病より月の 淺い、症狀の急激に出現せる例では好酸球增多を示し徐及に發病せる例では好酸球數は正常值を示しこれより 更に長い經過を經る例では好酸球减少を示寸。次にメチオジル投與によつてその經過を見ると臨床症狀基礎 代謝の好轉と共に一旦著しく減少せる好酸球が再び增加の傾向を示寸型(1)と好酸球の減少狀熊の長く縝く型 (2)と好酸球の變動が不規則な型(3)との 3 型に分けられる. (1)の型が經過最も良好である. 又44歲の女子のバ セドウ氏病患者で基礎代謝 $+75 \%$ を示するのがメチオジル投與により約10䢙間後基礎代謝 $+23 \%$ に減少する

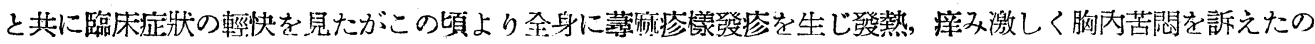

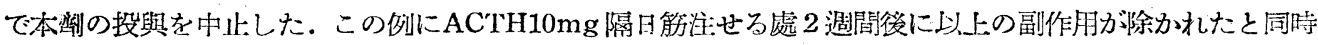

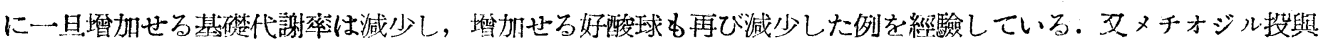
により不變の症狀を虽し基礎代謝も全く減少せ奴例で㚴娠後急速に基礎代謝の下降を示し人工中絶後及び分

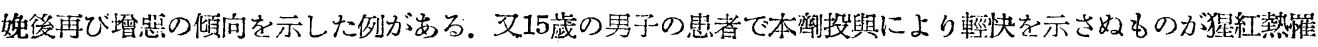
㭧後何等の處置を施すことなく2ヶ月後基礎代謝の減少々臨床症狀の輕快を見た。又本症で治潦中虫珽资の

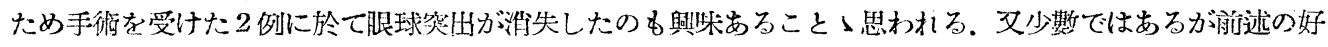
酸球減少と血清蛋白結合沃素との關係に於て後者が增加せる時は好酸球の減少度む著しいことを認めたので 併せ辫告し今後の檢案にまつことっする。

57. 家族性好腰球增多症之甲狀腺の關連性:

$$
\text { 京府醫大舘不內科 中 村 久 男 }
$$

家族性好酸球㒄多症は，1911年，Klinkert が初めて提唱したが，本症は我が國では約20例報告されれている。 
患者 長 $\bigcirc$ 龍○ 23 歲 女子

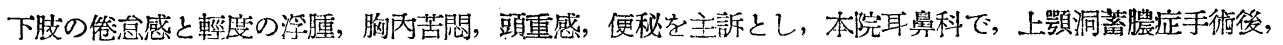

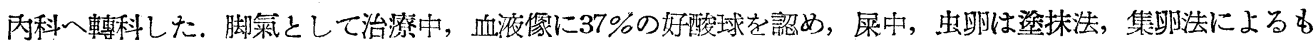
陰性, 藥効的檢查では, アドレナリン, ピロカルピンに反㗹し, 諸種の檢索によるも, 好酸球增多を來寸原 因不明のため，家族について檢查したところ，父 $3.5 \% ，$ 日25\%，姉 $5 \%$ ，妹 2 人に夫々 $23.5 \% ， 13 \% ，$ 弟 13\%の好酸球增多を認めた。本症の本態については, 古來種及と炋議され，Mayr u. Moncorps は脾贜 の機能低下のため，好酸球は血中に遊出すると述べ，小野崎等は，肝機能障碍のため本症が生ずると考えた。 內分汹腺々好酸球の關係については，機能立潐時には，減少をみること多く，機能低下時には，增加するこ とが多い，本症例では，䐉下㳛體及び副腎の機能には巽常を認めないが，甲狀腺の機能低下があり，血液沃 度量は蛋白結合沃度，遊離沃度何れも減少し，基礎代㛛低下，Vakat 沃度酸值係數は尿及び血液で輕度に

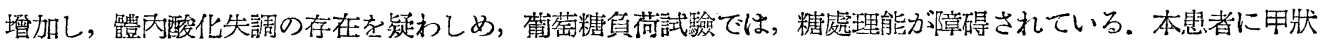
腺劑を投與したところ, 好酸球は $17 \%$ に激減し, 服用を中止すると, 再び $28 \%$ に增加した. 以上より, 本症 の本態には，甲狀腺機能低下が，重要な因子として藏惧すると考えられる。

58. 甲狀腺機能の硑究其一賀血と甲狀腺

東大美甘內科 染本 東一, 繁田 信, 太田 昭夫

粘液水腫や實驗的に起した甲狀腺機能减退症で䝳血が見られ又逆に甲狀腺機能㐫進症では赤血球增多症が 見られる事から甲狀腺のホルモンも造血機能に㬤係があるのではないか Domford 等によつて云われた。 又一方 Mansferd は最近甲狀腺から出るホルモンには Thyroxin の外に體溫調節に嚁係もる Thermocilyn と造血に關係あるがある Myelotropic Hormon があると云い，之等を分離抽出する方法迄述べている。私 達は此樣な侾から飨血と甲狀腺機能の關係を檢べた，先ず甲狀腺機能を檢べる方法としては1)基礎代謝測定 (クニッピング) 2) I 131投與後24時間後に甲狀腺に筷つた量をシンチレーションカッンターで外部から測定 寸る方法 3) I ${ }^{131}$ 投與直後より24時間內に尿中に排泄芑れる I ${ }^{131}$ の量を測定して間接に甲狀腺の I ${ }^{131}$ 攝 取量を知る方法 4) I ${ }^{131}$ 投與後24時間目にシンチグラムにより面積Sを測り直徑1を测りGoodwin の式 $\mathrm{W}=\mathrm{S} \times 1 \times 0.32$ によつて重量を知る方法 5) 丞白結合沃素を測定する方法 6) 血中 Cholesterol を測る方 沠等あるが今回は基礎代謝 (GU) 測定と2)の外部測定による方法を用いた。゙セドー氏病患者は 3 例夫々 $\mathrm{G}$

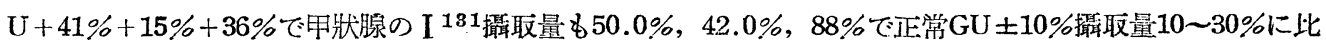
し何れも多く甲狀腺機能元淮を認めた。炏に頚血 3 例中，第 4 例は成形不全形賀血ザーリー30\%第 5 第 6 例

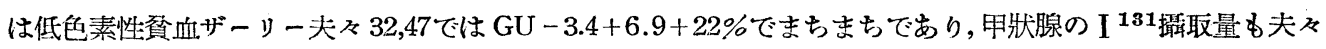
40.0，16.0，25.3と何孔も正常より多い．土屋は正常は日本人では $20 ４ 0 \%$ と云うが之よりも更に多い. 即 ち頚血症では甲狀腺機能は攝取量からは低いと云えない，比較のために見たGU - 2.1の蜘蛛指症の血色素ザ ーリー97\%の甲狀腺攝取量 $26.5 \%$ ，糖疗病患者の攝取量 $10.9 \%$ で基礎代謝と血急素，基礎代謝と攝取量の間

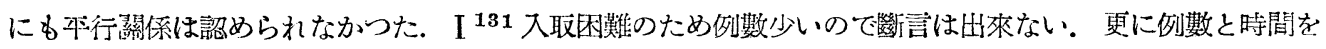
かけ他の機能測定法を併用して研究を續けたいと思う。偷外部测定は東大放射腺科土屋氏の手を煩した。

59. 甲狀腺機能の研究 (第 3 報) 甲狀腺疾㭧治繁時のホルモン等の沙長

群騳大七條內科 七條小次毁，由中茂，平林 敏秀，河村 研介，清水 敏一 別府野口病院 野口 秋人, 中野 稔

甲狀腺機能亢淮症20數例に對して，種及な樂物漝法を行い，その際の血中趣白結合沃度 (PBI) の變動を 追求し, 次で甲狀腺を剔出し, その後の血中PBI量を術䈘 2 日間に亘り, 頻回に測定して, 此と所䜋術後反

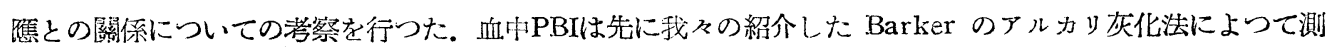

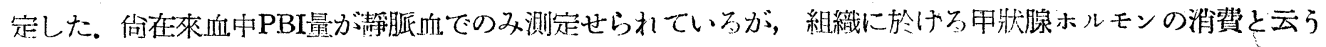


點より，動静脈血の美の有無について檢討した所，甲狀腺矤患及び甲狀腺以外の疾㭧の何れの場合に於ても，

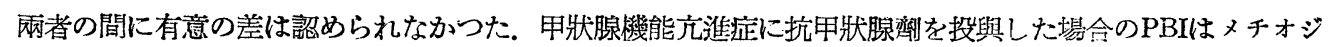
ールで最もその下降が著しく, 10 日後平均 $4 r / \mathrm{dl}$ 減少するが, ルゴールの投與ではその下降が弱く, 10日笋 $1.4 r / \mathrm{dl}$ 低下寸るに過ぎない.メチオジール及びルゴールの同時投與の場合はルゴールの單獨投與と略々同樣

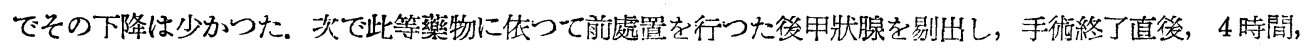
20時間，48時間に夫そ血中PBI を測定した結果は手術後より20時間までは變動が殆どなく，48時間後ではメ チオジール及びゴールで能處置した場合に 9 例中 5 例は明に減少した．ルゴール單獨では 4 例中 2 例は不變

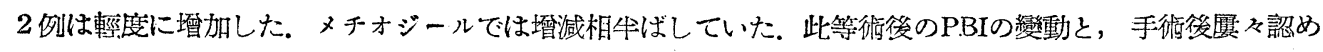

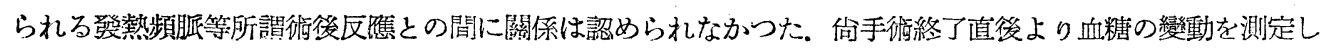

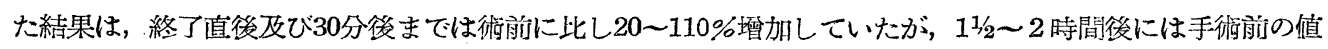

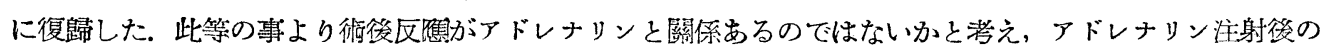
PBIの變動を湘定した所注射15分後稍及增加するものが多く，1時間後には大部分の場合PBIが注射前より 低い值を示した。斯る短時閪內に起るPBIの變動より，アドレナリンに依り甲狀腺よりのホルモン放出の減 少する䉆とするよりは末梢に於ける甲狀腺ホルモンの消費の增大が侾えられるが，此の點については更に檢 討中である.

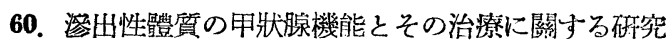

東邦大小兒科 久保 政次, 齊藤 郁郎

滲出性體質の血清PBIの母:本均信賴限界は $3.76 \pm 0.71 \gamma \%$ で正常兒に比し, 有意の美を以て低く, 血哖 コ レステロールは10例中， 4 例が暴常高值， 2 例が比較的高值を示し, 細胞外液は10例中 6 例が高值を示して いた，㕛粘液永腫の重要な症狀である化骨狀態を手根骨に就いてみると，化骨數は大體正常であるが，身長 に此し手根骨面積终和の暴常に小さいものが17例中 9 例, 大泉門の直徑は20例中13例が異常に大きく, 生蓉

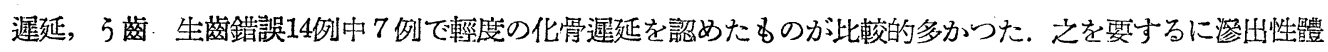
質は潜在性粘液水腫が比較的多く，概して甲狀腺機能減退傾向にあるといえるのではないかと思う。

そこでこの甲狀腺㙨能減退が下垂體前葉からの TSH 分泌不全による二次性のものが，或は原發性のもの かをかん別せんとしてヒポホリン30家雨單位 (FSH, TSH は含有するがACTHは殆んど含有しない)を注㴬 し PBI の消長をみるに, 正常兒よりも P.BIの上昇度が大きかつたので下政體性の甲狀腺機能減退を推定さ

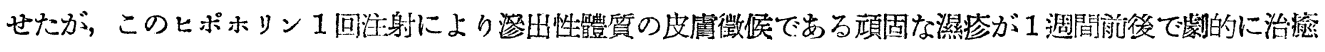
することを知つた $(6$ 例中 6 例全治). 叉サイロキシン含有量が1％で甲狀腺末より副作用が少いといらヨー ドカゼイン（1 日量0.1 0.2g）の內服でも同樣主好があり26例中，24例が全治した。病型別治漝効果は濕潤

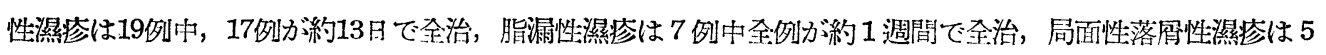
例中 3 例が全治した，本潦法の作用機輔は甲狀腺㙨能を正調し，脂質代謝に影響にあたえ，細胞外液を減少 せしめるためであると思 5 .

61. 實羷的ビタミンB6欠方症の甲狀腺機能

名大分院內科 山田 弘三，伊藤 清次

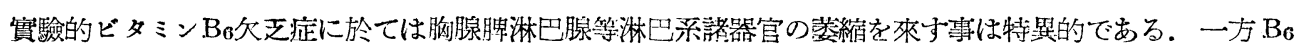
は一定のアミ/酸の脫炭酸醉素アミノ基轉移酵素に緊與寸るを初め蛋白, 脂肪, 糖質其の他鑛質代謝にも深

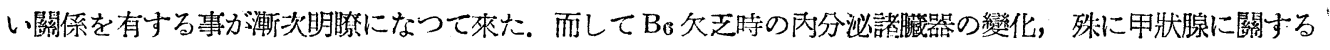

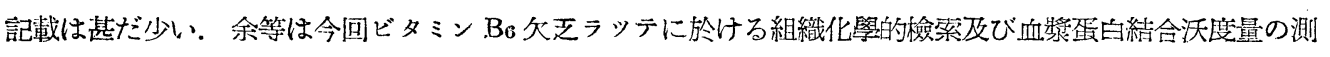
定を行つた.

動物は60〜90g 大の雄性ラッテ32匹を使周，1グループ4匹宛を體重の近いものより選び，1グループを

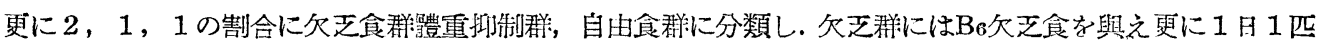




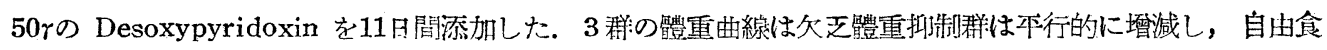

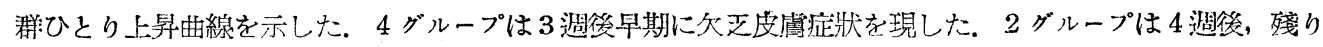
2 グループは 6 迵後心穿刺友び甲狀腺摘出を行つて材料に供した。

組織化學的檢慗には HXーエオジン染色及び Heideahein 氏鐵へマトキシリン染色を行つた，組織的に

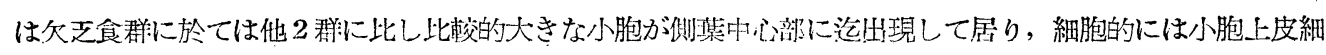
胞の高さが他2群に比し低くなつて居るのを認めた，以上の變化は $4 ， 6$ 䢙に於て顯著である。

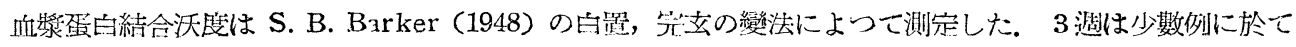
暼加しているが，大部分は不變或は明らかに減少，4，6楝では多くの例に於て極度の減少を見た。體重抑 制群·では一部分逆に䪺加し, 大部分は減少した。

以上組織化學的及び血漿蛋白結合沃度の成續を件せ洘え，ビタミン，B6 火灭時に於ける甲狀腺機能の障害 を推論した，而して經過につれて高度になるものと思われる。

62. 各種植物成分の甲狀腺機能に及ぼす影響に就いて

群馬大七條內科 七條小次郎，小谷 愛子，稆田 信男

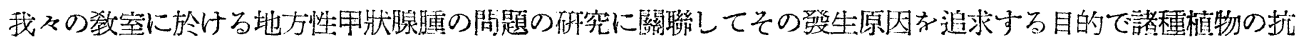
甲狀腺性について檢查した成縝を郝告する。

先ず Astwood の方法により各種野荣のエーテル抽出物を Beckman の Spectrophotometer にてその 紫外線吸光度を測定した．その結果アブラナとキャベッの種子では $240 \mathrm{~m} \mu$ に最大吸光度を示し, $22.0 \mathrm{~m} \mu て ゙ は$

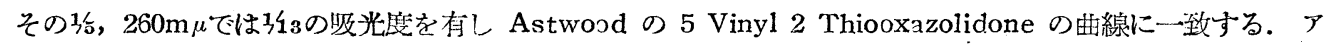

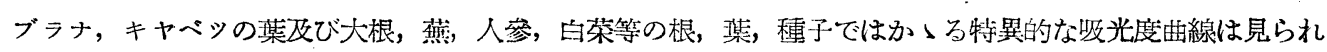
ず大根, 燕等では $270 \mathrm{~m} \mu$ 前後に最大吸光度を有する緩かな曲線を得た。

之等植物抽出物が甲狀腺の沃度攝取能に及ぼす影響を豚の甲狀腺を用いて行つた實驗では沃度攝取能は溫

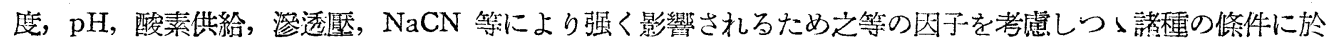
ける之等抽出物の作用を觀察した。切片を谏結及びェーテル處理を行つても丈之を行わ奴場合る之等抽出物 は上述の L-5-vinyl-2 thio oxazolidone つ有瞧に拘らずすべて或程度の沃度掫取阻碍作用が認められる. この婜之等抽出物と沃度との化學的結合を考慮して切片を預め抽出液で前處置を行つた後に放射性沃度を加 えた Krebs-Ringer 源中に放置したが之に位つては之によつては白荣種子の外はすべて同樣に沃度攝取阻 碍作用が認められ，又抽出物に無機沃度を加之た前後に於ける紫外線吸光度には變化を認めず之等から單な る化學結合では說明し蜼く思われる。凍結灭びェーテル處理を行わ奴切片て酸素を充分供給して行つた場合 は L-5-vinyl-2-thiooxazolidone を含むキャベッ及びアブラナの種子は之を含ま好ものより强い沃度攝取の 阻䅞を示した。

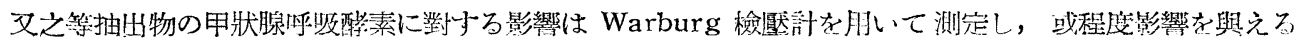

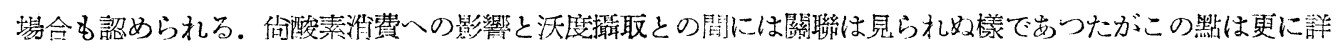
しく檢討する積りである。

63. 二，三の薬狱によう甲狀腺機能の變動について

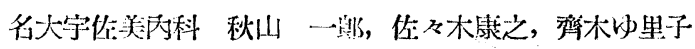

甲狀腺機能の元進せる甲狀腺疾患にはルゴール氏液の階段的投與とメチオジールの $0.1 〜 0.3 \mathrm{~g}$ の渐增法と の併用潦法を約 1 ケ月行い，肥滿した健康人及びネフローゼ症候群を呈した腎疾患者には乾燥甲狀腺未 1 日 量0.2g或いは有機沃度製沾たるプロヨーゲン 1 日量 $1.0 \mathrm{~g}$ を使用し約 2 涸閒後に甲狀腺機能を測定した。 甲 狀腺機能檢查としては血清蛋白結合沃度 (Barker のアルカリ灰化法), 基礎代謝亱(Knipping 氏の裝置),

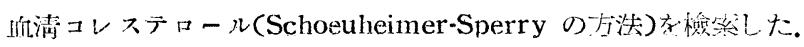




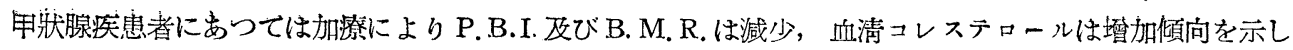
たが，P.B.I. 及びB.M. Rが正常值に戻つたものは極く小數例であつた.

肥滿せる健康人にては藥劑の服用によりP.B.I. 及びB.M.R.は共に增加傾向，血清コレステロールは減少 傾向を示したがその度合は輕度であつた。

ネフローゼ症候群に於てはP.B.I. 欧びB. M. R.は不變或いは增加を示したが，その度合は輕度であつた。 而しながら血清コレステロールは著明な減少を示した。

以上の賽驗成縝から谷の樣に結論することが出來る。

1）ルゴール氏液及びメチオジール末搠用潦法は甲狀腺機能克進せる疾患に對して著明な効果を及ぼすが， 短時日に正常狀態を來たすことは四難と思うれる。

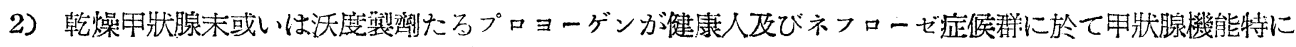
P. B.I.の著明な增加を來さないことは，血中P. B. I. の調節に腦下垂體が甲狀腺と共に重要なる役割を演じ ていることが推測される.

3）ネフローゼ症候群におけるP.B.I.の低值が沃度劑によつて正常值えの復歸が認められないのは，ネ フローゼのP.B.I.の低值が甲狀腺機能の減退と直接的關係を有するものでないことを示するのと考える.

64.甲狀腺組織の酸素消費に后ぼす自律神經作用物質 (Acetylcholine, nor-Adrenalin)の影響 群馬大內分泌矿究所 山本 清, 井上 博夫

甲狀腺と自律神經系との機能的連關をうかがう目的で，組織の酸素渻費を機能示標として in vitro の實

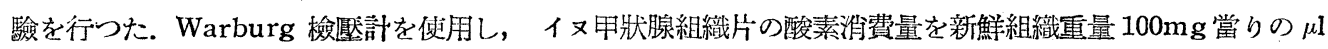
であらわし, acetylcholine, nor-adrenalin, vagostigmin を添加した影響について觀察した。

1. Acetylcholine (Roche) の終末濃度 $10^{-3} \sim 10^{-7} \mathrm{M}$ で，はじめ約 1 時間は酸素消費が促進され，後には 却つて抑制される. 實驗前期の促進，後期の抑㸝共に acetylcholine の濃度が高い程大である傾向がある.

2. Vagostigmine は終末濃度 $10^{-4} \sim 10^{-6} \mathrm{M}$ て酸素消費に大して影響しない. $10^{-4} \mathrm{M}$ Vagostigmine を acetylcholine に併用すると，實驗前期の酸素消費促蕉，後期の酸素消費抑制の度を高める傾向が見られる。 3. $0.5 \%$ 濃度にブドウ糖を加えて酸素沙費を行わせると, acetylcholine の終末濃度 $10^{-2} \sim 10^{-5} \mathrm{M}$ で 2 時 間以上に亘り著しい酸素消費の促淮が起つた．10-4 Mの濃度で促進作用が最も强かつた。 4.この場合.

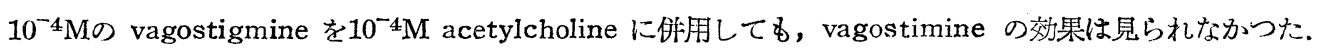
5. d,1-nor-Adrenalin (三共) の終末濃度 $4 \times 10^{-4} \mathrm{M}$ 涯加では酸素消費に變化がなかつた。

以上の結果から，呼吸の基質としてブドウ糖が十分在る場合には，甲狀腺の酸素消費が acetylcholine に より著しく促進されることが明かで， acetylcholine を㗹達物質とする副交感神經興奮が甲狀腺機能に影響 することを示唆する。また，酸素沙費を機能示標とする in vitro の赛驗では呼吸の基質についての洘䲘が 重要なこと, acetylcholine は 2 時間以上効力を保つこと, vagostigmine, nor-adrenalin は甲狀腺瞈素淮 費にほとんど無影響なこと，などが示された。

65. 高温環境と甲狀腺

$$
\text { 陇大第一解剖 藤 田 }
$$

甲狀腺濾胞間上皮細胞が分泌機能を有寸る細胞であることは，既に確認されてている所であるが，その分泌 機轉立びにその作用が甲狀腺機能の如何なる部門を擔當するかに關しては, 未だ明らかでない. 叉高溫袔有 動物の血清が高溫に對する抵抗力を强め，而して甲狀腺がこの際重要な役割を演じている䟬は既に報告され ているが，その詳細な細胞學的觀察は未だ鳻されていない，余は次の實驗を試み，興味ある所見を得たので 郝告する。

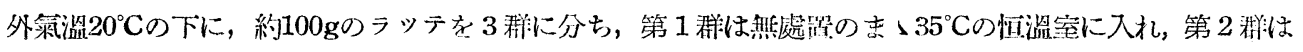


$35^{\circ} \mathrm{C}$ の恒溫室に72時間飼育せるラッテの血清を腹腔內注射して $35^{\circ} \mathrm{C}$ 恒溫室に入れ，第 3 群は $8^{\circ} \mathrm{C}$ の泠室にて 72 時間鶬育せるラッテの血清を腹腔內注射して $35^{\circ} \mathrm{C}$ の恒溫室に入れ，何れる投入後 $1 ， 3 ， 6 ， 12$ 時間にて 取材した.

濾胞間上皮の微細構造より，その分泌機能を靜止型，中間型，洋動型に三大別し各期に於ける百分比をと つた所.

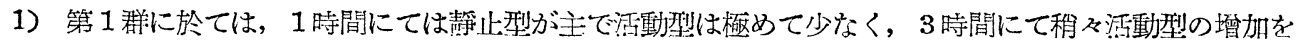
認め, 6 時間に於ては著明な增加を認め, その後稍々減少するる旺盛なる活動狀況が見られた。

2) 第 2 群に於ては， 6 時間に至るも活動型の增加は殆んど認められず，12時闌に至り初めて活動型が增 加するのが認められた。

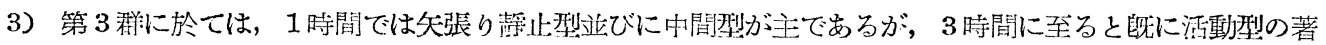

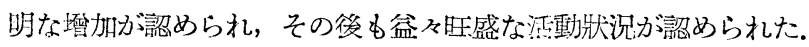

以上の所見より，雐胞間上皮細胞は溫度環境の變化によつて機能的動態を示すことを知り得た。

66. 脾內甲狀腺移植賽驗

群馬大婦人科 不 原 力

成熟此ラシッテに於て甲狀腺の脾內移植を行い，對照には婜，及び背側皮下に移相を行い，一部にはメチ才

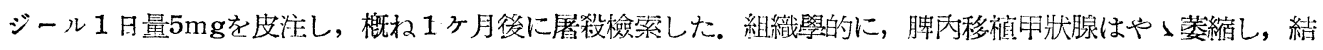
合織が中心部に入り込んでいるものるみられた。一般に上皮細胞は厚く，コロイドは一部では保存されてい、 るが少く，所謂機能无淮像に近い所見である．問質の毛細血管は減少し，一般に賀血している．メチオジー 儿處置のものは，明かにその作用が認められたが，但し正常位置にあつて處置されたものにみられる程强く はない，一方謦內移植甲狀腺では, 上皮の高さはそれ程扁本でないが，濾胞が一般に大きく、コロイドも豊 富である. 皮下移植には著變がなかつた. 以上から，Lipschutz 手術 (脾內畉巢移植) との類似よりみて， 脾の血流が凡て通過寸る肝に扒ける甲狀腺ホルモンの非㒋化の可能性が䕎示されていると濐えられる。

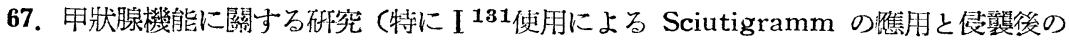
甲狀腺機能の變動について)

\section{東大放射線科 江藤 秀雄, 筧弘 毅, 土屋 武㝘 東大木本外科 龇澤喜守雄，石井 淳一}

甲狀腺に於ける I ${ }^{131}$ 分布狀態を知り，甲狀腺の病的狀熊を知るため，Sciutillation counter を用い

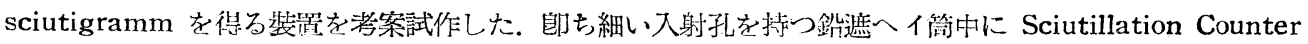
收收め之を甲狀腺上を走查し，一方 Scala より連綃してネオンランプを鼔減させ之を乾板上に感光させ

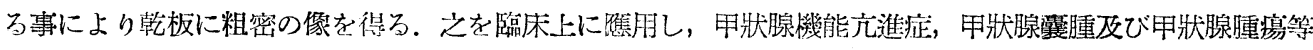
の患者に於て試み，甲狀腺の形狀及び襄腫の存在位䁌等を明らかに示し得たので，12例の Sciutigramm

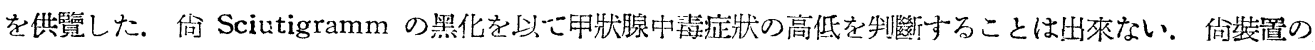

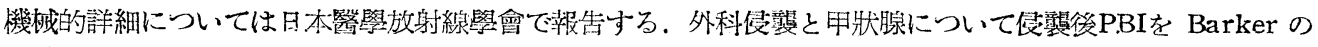

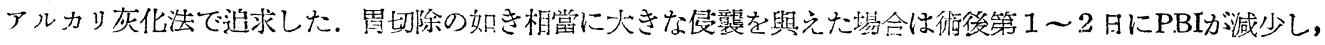

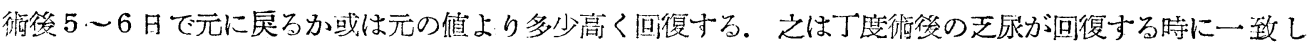

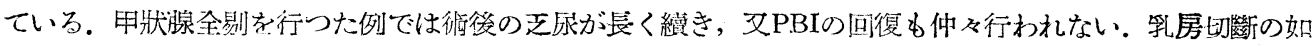

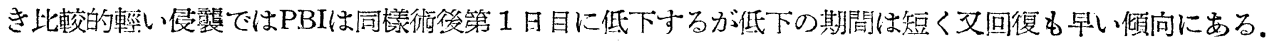


68. 放射性沃度 I ${ }^{131}$ による甲狀腺クリアランスについて

新潟大鳥鸰內科 熊 岡 爽 一

I ${ }^{131}$ によつて甲狀腺の沃度集積力を測定する祭に，甲狀腺外の因子を除去する目的で， I ${ }^{131}$ の甲狀腺攝 取量と血清濃度との 2 者から甲狀腺クリアランスを測定した。

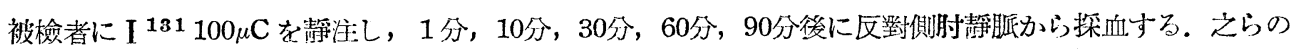
血液は血清を分離してその $0.5 \mathrm{cc}$ を凟料四にとり赤外線ランプにより徐々に乾燥せしめる。この標本は $\beta$ 線 計測により一定量の標淮と此較してその放射能灰測定する。 I ${ }^{131}$ の標淮に健康人血清 $0.5 \mathrm{cc}$ 加えるとその 計數は自己收收により $72.2 \%$ に減少するので，血清標本の放射能は血清を加えた標潐に基いて算出する．以 上の樣にして得られた血中甄度曲線は10分上後からは略々指數函數曲線となるので, 片對數グラフの對數軹 に放射能值をとり，横軸に時間をとると直線となる。この直線は最小 2 回の探血によつて得名事が出來る. 甲狀腺クリアランスは I ${ }^{131}$ 投與後10〜90分間の血清 I ${ }^{131}$ 濃度の本均值を上記圖表から算出し，之を80倍し たるのでこの時間內に於ける甲狀腺の I ${ }^{13} 1$ 攝取量を除して得られる。甲狀腺の I ${ }^{131}$ 攝取量の外部計測には

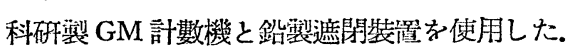

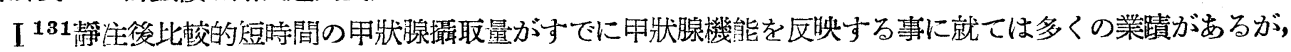

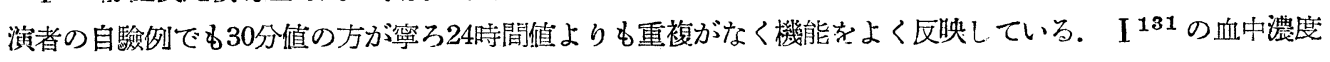
は甲狀腺機能立進の狀態では速かに減少し, 粘液水價では減少が进く, 正常人は中間に位する。

甲狀腺クリアランスは11例の正常人では11.5から $34 \mathrm{cc} の$ 範睹にあり，18例の甲狀腺機能㐫進症では62から $634 \mathrm{cc}$ 範袁にあり，4 例の粘液水腫では $8 \mathrm{cc}$ 以下であつた. 甲狀腺クリアランスを片對數グラフの對數軸 にとり PBI と對比すると兩者は密接な平行關係を示す。な打單純性甲狀腺腫に於ても, 又低蛋白血症でPBI の減少している場合であ甲狀腺クリアランスは正常值を示した。

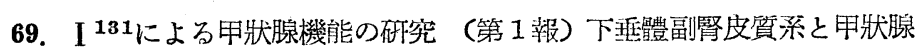

東大田坂內科 田坂 定孝, 小田 正幸, 岩岡 順, 片岡 兑本

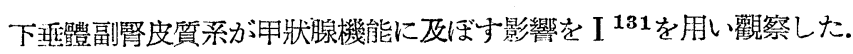

白鼠を, コーチゾン, DOCA, ACTH, アドレナリンを各 8 日間注射した 4 群, 兩側副腎摘出後コーチゾ

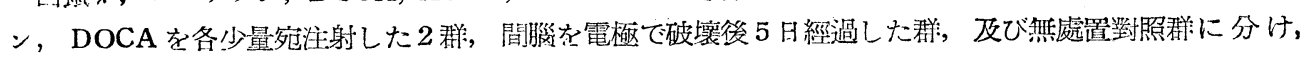
I ${ }^{131} 20 \mu \mathrm{C}$ 宛を腹腔內に注射，24時間後屠殺，得た甲狀腺，血漿，尿について放射能を測定した。測定には G. M. 管及び一部はシンチレーションカウンターを使用, 甲狀腺はr線を, 血漿及び尿は主として線を測定 した.

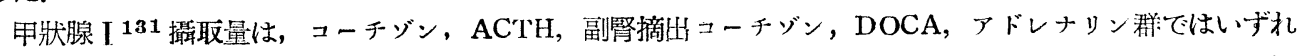

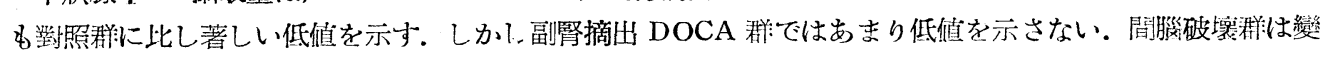
化字示さない。

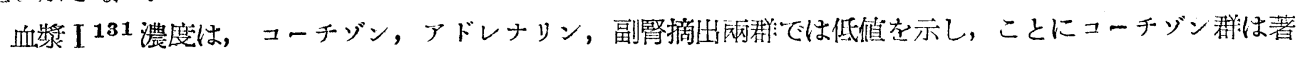
しい低下を示している。

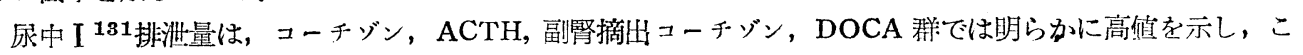

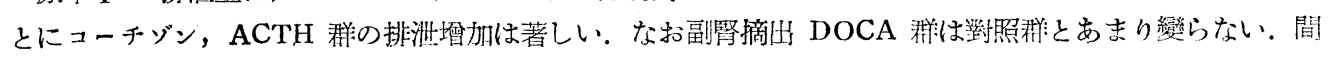
授破壤群では排泄增加している。

以上の I 131 進跡實驗の成䋶から，コーチゾン，ACTH，DOCA，アドレナリン投與により甲狀腺機能は 明らかに低下する。ことにコーチゾン，ACTH では著しい，ACTHによる低下は恐らくューチゾン分泌の

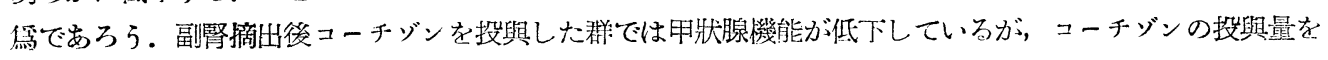

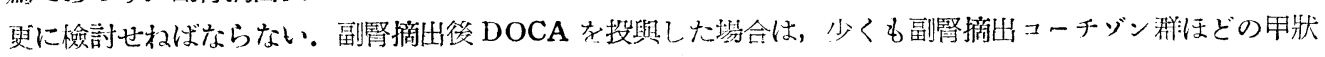


腺機能低下は認められなかつた。この點について現在檢討中である。間脛破壞の場合には，申狀腺攝取量， 血漿濃度に變化は認められなかつたが，尿中排沺量は管加し，甲狀腺機能の低下を思わせる。

70. 放射性沃度 I ${ }^{131}$ によるバセドウ氏病の治潦經驗

新潟大鳥鶬內科 熊 阙爽 -

15例のバセドウ氏病患者に治療量の I 131を投與し，次の樣な結果を得た。

充分な効果をみた 5 例ではBMR は夫々 $+70 ， 69 ， 50 ， 60 ， 36 \% ， \mathrm{PBI}$ は夫々 $16.0 ， 14.7 ， 9.2 ， 11.1$, $6,4 . r \%$ ，甲狀腺重量は夫及 $29 ， 51 ， 30 ， 30 ， 50 \mathrm{~g}$ ，脈搏數は夫及 $100 ， 120 ， 106 ， 100 ， 92$ ，甲狀腺》リアラ

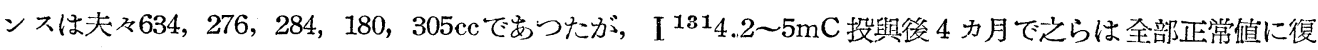
した.

I 131 の追加投與を要した 5 例“では BMR は夫及+46，59，111，107，80\%，PBI は夫及 $13 ， 14 ， 19.5$ ， $19.9 ， 14 \mathrm{r} \%$ ，甲狀腺重量は夫及 $30 ， 25 ， 63 ， 111 ， 142 \mathrm{~g}$ ，脈搏數は夫及 $88.88 ， 108 ， 84 ， 100$, 甲狀腺クリ アランスは夫љ $62.2 ， 134 ， 309 ， 433 ， 126 \mathrm{cc}$ であつたが，I 131を2.5 7mC投與後 6 カ月にいたるも正常犆 に復せず，再び恐化の傾向も見え，殊に大なる甲狀腺腫炎有するものはその縮小も不充分であつたので， 4 ～6 $\mathrm{mC}$ を追加投與し 2 カ月後に BMR は夫々 $-8.8 ，+36 ， 18.3 ， 64.7 ， 36 \% ， \mathrm{PBI}$ は夫々 $5.2 ， 6.2 ， 4.5$, $10.1 ， 7.1 \gamma \%$ ，甲狀腺重量は觸れず，觸れず，78.2，112.5，99g，脈搏數夫及 $60 ， 72 ， 72 ， 88 ， 68$ となり， 自覺的にも好轉しているが，甲狀腺腫不變のものが 3 例あるので，經過憼察中である，

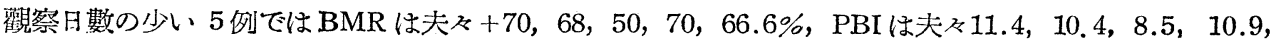
$19.3 \%$ ，甲狀腺重量は夫ぬ $51.5 ， 30 ， 30 ， 39 ， 33.3 \mathrm{~g}$ ，眽搏數 $116 ， 88 ， 64 ， 88 ， 132$ であつたが，之に ${ }^{131}$ を3〜9mC投與し 2 カ月觀察して居り，全例に甲狀腺腫の縮小を見，相當の効果を認めるが，未だ充分とは 言えない.

I ${ }^{131}$ によるバセドウ氏病の治漝は朋法が簡單である上に，充分な量を用いれば効果が確實で，血液像そ の他に對する副作用は認められない，眼球突出の輕快学夕た例はないが，他の眼症狀は改善される。I ${ }^{131}$ は甲爿腺腫の大なるもの程大量を必要とする。

71. 放射性沃度 I ${ }^{131}$ 治漝後, 低血糖を來した重症バセドウ氏病の一例

大阪市大小田內科 藤田 榮一, 藤田 惠三, 川口 自由, 河南清入郎

昨年本學會で放射性沃度 $\mathrm{I}^{131}$ に㳖るバセドゥ氏病の治漝について報告したが，その中の1例は I ${ }^{131}$ $4708 \mu \mathrm{C}$ 經口的に投與し， 6 ケ月後に自覺症狀輕快，體重唒加，胍搏减少，眼球突出及び甲狀腺腫の減少 等を認めたが，基礎代謝萃は+74\%で治潦前に比し僅か９％の減少を示したのみであり，特に肝機能は投與

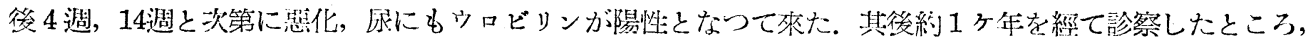

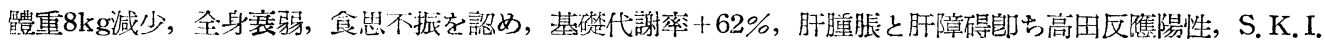
5であつたが，モイレングラハトは11，尿ウロビリン體は陰性であつた，血液像では輕度の頚血，白血球減 少を認め, ACTH 25mg筋注4時間後の好酸球減少率は25\%で, 尿 $17 \mathrm{KS} は$ 低く $3.323 \mathrm{mg} / \mathrm{day}$, 尿 Corticoid,

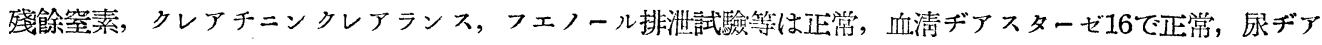
スターゼ8で低く, 尿糖陰性, 空腹時血糖41mg/dlであつた。これに Master の二階段試驗の 4 倍量を負荷し たところそその牛ばにして極度の脫力感を訴えた舀中止，其後の血糖值は 5 分後 $23 \mathrm{mg} / \mathrm{dl}, 2$ 時間後 $20 \mathrm{mg} / \mathrm{d} 1$

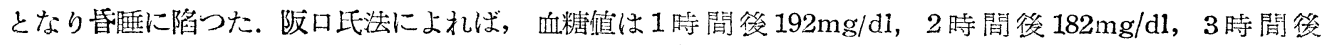

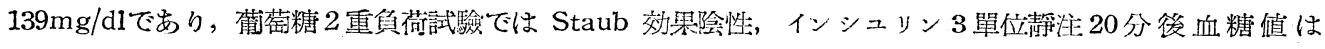

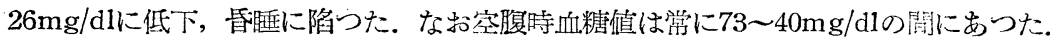

以上總括すると明かに肝機能障碍による所謂肝性低血糖症と考えられる。然しこれが I ${ }^{131}$ の影響による

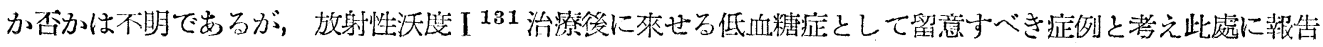


拓。

\section{2. 甲狀腺疾患に於け当放射性沃度の診斷的陮用}

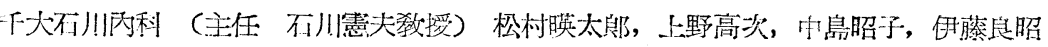

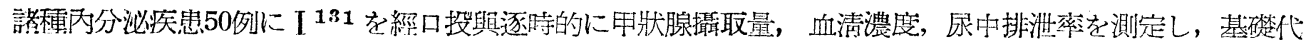

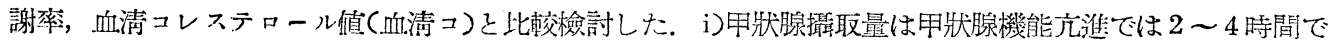
最高となり上後斥行し，健常者は前者に比して低く，甲狀腺機能低下は更に低く一部健常值と重複する。ii) $\mathrm{I}^{131}$ 血清濃度は機能㐫進では30〜60分で最高となり 上後急速に下降するが機能克淮著明なる者に 6 時間值 の再上杽せるを認む，機能低下では最高值高く，下降も緩慢で，健常者は兩者の中間を示す．iii) I ${ }^{131}$ 尿中

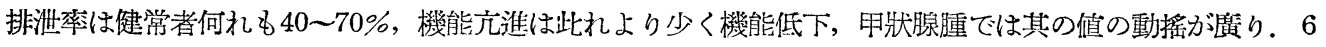
時間と24時間の尿中排泄菜の間に相關を認む。メチオデール服用は I ${ }^{131}$ 追跡子試驗に著明なる影響を與え る. 基礎代謝率は甲狀腺機能元淮, 健常, 低下の間の重複は少いが機能元進にて健常值を示するのあり，血.

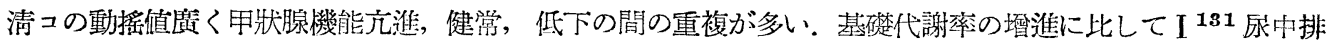
泄率の減少著明にして I ${ }^{131}$ 尿中排泄率は基礎代謝率より機能元進を明確に示す．甲狀腺機能光淮症にメチ オデール，VB1併用潦法を實施しその前中後に諸種甲狀腺機能檢查を行つた。郎ち臨床症狀輕快々共に基整 代謝率, 血清コ好轉し 漸次健常值を示する I ${ }^{131}$ 尿中排泄率の健常值を示すは前者に比して逮く略治すると 共に健常值化するものの如くである.

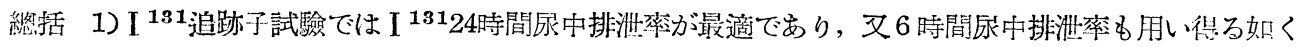
思われる. 2)基礎代謝率は諸種要素の影響受けやすく, 甲狀腺機能光進症と健常者とのグレンッグビートで

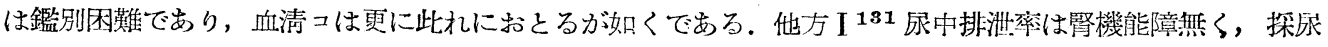
の正確を期するならばその診断能の 2 者に勝ると考うるも, 各暴れる面より見た甲狀腺機能檢查法なる故 3 者綜合して甲狀腺機能を制定すべきである。3)甲狀腺機能光淮症のメチオヂール，VB $B_{1}$ 併用潦法に際して は基礎代謝率，血清コの好轉は $\mathrm{I}^{131}$ 尿中排洲率の好轉より早期であるものの如くである.

73. 放身性沃度及び血清P. B. I.による甲狀腺機能檢查知見並びに單純性:甲狀腺脾の ヨードカゼイン潦法に就て

二大小兒科 伀及木哲丸，中鳥博德，森 和夫，津田康之，有吉 徹，份及木巟三

單純性甲狀腺腫 40 名, 正常人 25 名, 甲狀腺腫を伴光る粘液水腫 3 名, 甲狀腺機能克進症10名を對照として, carrier free の I ${ }^{131}$ を静注して, 尿, 血清, 甲狀腺中 I ${ }^{13}$ 量推移を測定し, 血清 P. B. I. と共にその甲狀 腺㙨能を檢索し，單純性甲狀腺腫の發生機序を考究して，その治潦を行つた。

先ず正常人により正常值を定めると，本症の血清P. B. I. 值は殆しど正常值を示し，24時間尿中 I ${ }^{13}$ 量は 本症の3\%は正常值を示すが，1亿は低值を示し，且つ血清 I ${ }^{131}$ 推移曲線は低位を示し，甲狀腺 uptake は高 值を示す，一方甲狀腺腫を伴える粘液水腫も此等149本症と同樣なる成結を示した．そこで單純性甲狀腺腫 と甲狀腺腫を件万粘液水腫とはその機序に類似性を認めた。一方甲狀腺機能克淮症に於ては，24時間上後の 血清 $\mathrm{I}^{131}$ 推移曲線を見ると, 單純性甲爿腺腫, 正常人とは逆に, 上昇曲線を示すことを見た.

そこで，本症は甲狀腺の I 濃縮力は旺盛であるが，何等かの原因によるホルモン生成乃至分泌の障碍があ り，焉に甲狀腺の代償性肥大を起したものと考え，本症のヨードカゼイン潦法を試みた。ヨードカゼインは 電氯透析にて無機 I を殆んど無にしたもので， 1 日，0.15gを連續服用せしめた。その結果，本症35名中現 在迄に $88.6 \%$ 闸狀腺縮少の効果を認め, 上記の考えを裏付けた．治潦効果は投與後 3 週以內に最大にして, ビマン性は結節性より，腺腫發生後の期間の短いものは長いものよりも何れも効果が良好で，副作用は全く 認められず，體重減少も大部分認められなかつた。

本症の乾燥甲狀腺劑による治潦は既に1894年, Reinhold, Bruus 等により行われその卓効が認められた 


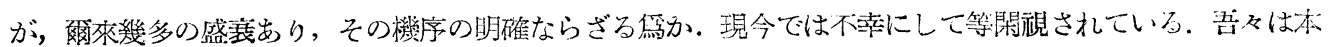
症の甲狀ホルモン潦法の合理性を確認し, 更に甲狀腺璾よりも安價にして副作用の少いヨードカゼイン潦法 を提唱したい。

74. ヨードカゼイン投與㭙のカヒウサギの生體變化について

化學潦法病理（伊觶正夫）山田

弘

幼若なカヒシサギ18牙を用いて表のような實驗を行つた。

對照動物の體重はずべて䪺加, 䔈驗動物ではヨードカゼインを經口投與したものの數例を除いてすべて減 少を示した。

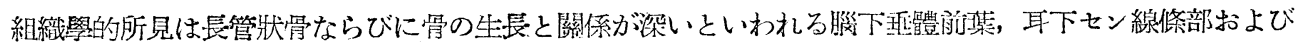
副甲狀センなどに一定の變化が汉られた。

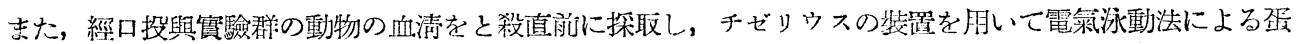

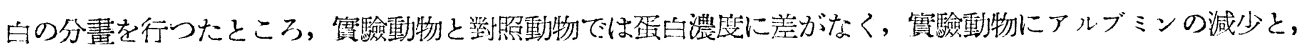

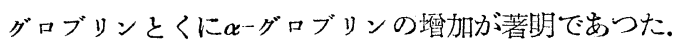

注射に用いたヨードカゼインは千葉大學藥學部湊敉授の合成分與されたもの, 內服に肺いたのはプロヨー ゲン「トモエ」であり，乾燥甲狀腺はチレオイド「三共」のである。

實驗方法

\begin{tabular}{|c|c|c|c|}
\hline 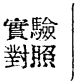 & 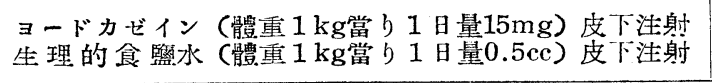 & 14日 & 同 腹 \\
\hline 貫驗 & 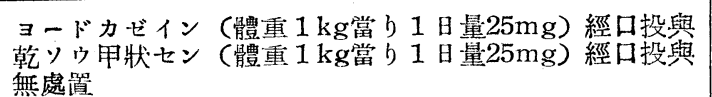 & $7.14 .21 \mathrm{~B}$ & 同 腹 \\
\hline
\end{tabular}

組織學的所見

\begin{tabular}{|c|c|c|c|c|c|c|c|}
\hline & 長管狀骨 & 臘下开體前㯲 & 甲狀セン & 副甲狀セン & 耳下セン & ガク下セン & 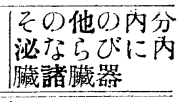 \\
\hline 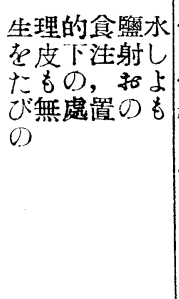 & 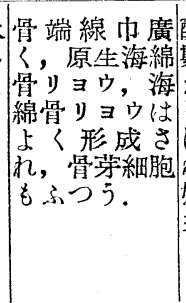 & 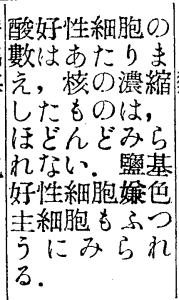 & 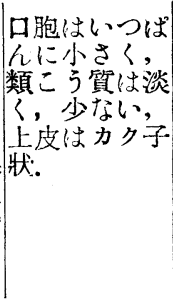 & |異常はみられ & \multicolumn{2}{|c|}{ 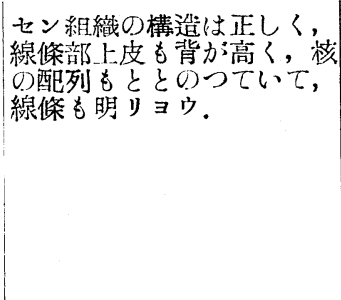 } & 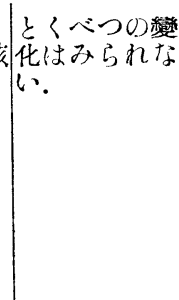 \\
\hline 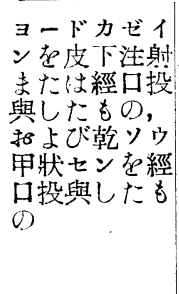 & 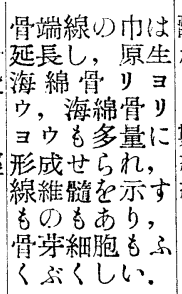 & 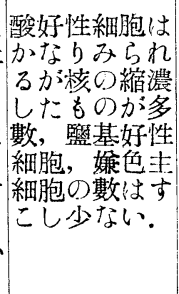 & 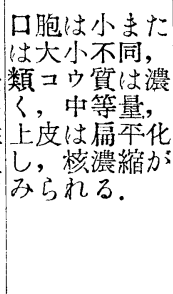 & 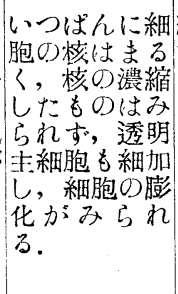 & \multicolumn{2}{|c|}{ 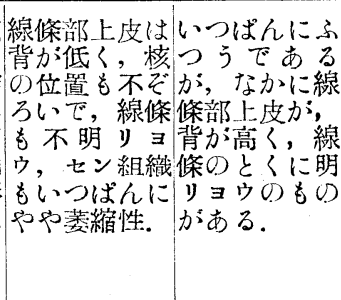 } & 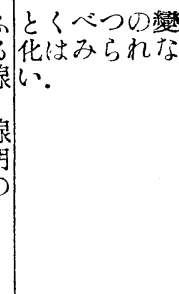 \\
\hline
\end{tabular}


電氣泳動法(チゼリウスの装置)による血清タン分屃百分崇

\begin{tabular}{|c|c|c|c|c|c|c|c|}
\hline $\begin{array}{l}\text { ウサギ } \\
\text { 番 號 } \\
\end{array}$ & アルブミン & $\alpha$ グロブリン & $\beta$ グロブリン & rーグロブリン & タン白濃度 & 處 置 & 期 閏 \\
\hline $\begin{array}{l}29 \\
27 \\
32\end{array}$ & $\begin{array}{l}60.8 \\
62.4 \\
64.5\end{array}$ & $\begin{array}{l}10.6 \\
12.4 \\
12.75\end{array}$ & $\begin{array}{l}19.1 \\
18.1 \\
17.1\end{array}$ & $\begin{array}{c}9.5 \\
10.85 \\
5.15\end{array}$ & $\begin{array}{l}5.9 \\
5.1 \\
6.0\end{array}$ & 無 處 置 & $\begin{array}{r}7 \text { 日 } \\
14 \text { 日 } \\
21 \text { 日 }\end{array}$ \\
\hline $\begin{array}{l}21 \\
24 \\
26\end{array}$ & $\begin{array}{l}46.2 \\
49.2 \\
47.3\end{array}$ & $\begin{array}{l}16.8 \\
22.9 \\
19.9\end{array}$ & $\begin{array}{l}19.4 \\
17.7 \\
18.1\end{array}$ & $\begin{array}{l}17.6 \\
10.2 \\
14.7\end{array}$ & $\begin{array}{l}4.9 \\
5.1 \\
5.7\end{array}$ & $\begin{array}{l}\text { ヨードカゼイン } \\
\text { 經口投與 (1 日 } \\
\text { 量體 重 } 1 \mathrm{~kg} \text { 當 } \\
\text { り25mg) }\end{array}$ & $\begin{array}{r}7 \text { 日 } \\
14 \text { 日 } \\
14 \text { 日 }\end{array}$ \\
\hline $\begin{array}{l}28 \\
25\end{array}$ & $\begin{array}{l}47.0 \\
49.8\end{array}$ & $\begin{array}{l}21.1 \\
23.6\end{array}$ & $\begin{array}{l}19.0 \\
13.7\end{array}$ & $\begin{array}{r}13.1 \\
7.9\end{array}$ & $\begin{array}{l}5.8 \\
5.0\end{array}$ & 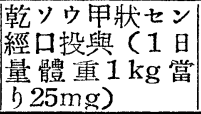 & $\begin{array}{r}7 \text { 日 } \\
14 \text { 日 }\end{array}$ \\
\hline
\end{tabular}

75. 小兒血清蛋白結合沃素(P.B.I. )に關与る研究

東邦大小兒科 久保 政次, 稻萝 萃子

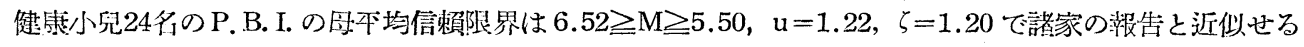

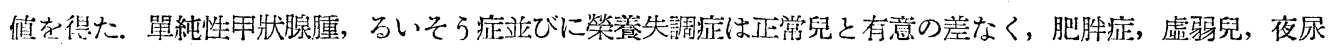
症, 自家中毒症, 神經質は正常兒に比し有意の差を以て低々, 甲狀腺機能无進症, 腧腺肥大症, 腦炎は有意 の差を以て高かつた。次に潜在性:粘液水腫に牛甲狀腺 ( 1 個) 埋没によるP. B. I. の消長は同乳劑济㴬に比し

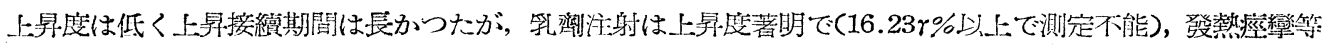
の副作用を伴つた，ホルモン沟ではヌガビオン不變，オバホルモン減少，ACTH少最 1 回注射不變，大量

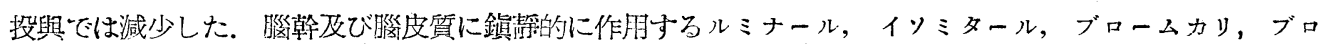
一ムカゼインは何れも減少, 自律神經毒のニューロギン, アトロピン, ピロカルピン, アドレナリン, エフ エドリン等何れも不變, T. T.G. 增加, ヂニトロフェノール, メチルサイオュラシールは減少した. P.B.I.

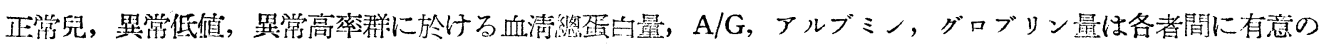
差なく, 又アルブミン正常, 低アルブミン血症, 高アルブミン血症及びグロブリン正常, 高グロブリン血症 間に於けるP.B.I.にも有意の差は認められなかつた。

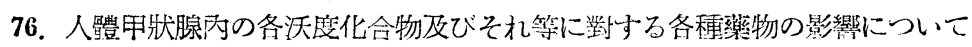

$\begin{array}{ll}\text { 群馬大內科 田 中 } & \text { 茂 } \\ \text { 野口病院 野口 秋人, 中野 稔 }\end{array}$

甲狀腺機能艺進症に對して現在主として月いられている樂物の治潦効果の比較及びその作用機序の檢索を 行万䉆, 種々な組物を投與した時甲狀腺を剔出し，その中に含まれる备ヨウ素化合物を定量し，又一方血中 P.B.I.との關係を生求した。 甲狀腺中の各ヨウ素化合物の測定法として從來用いられている方法は甲狀腺 を水解後 Leland \& Toster 或いはBlau の方法に依つてョウ度化合物を分ち，その中に含まれる夫及の ヨウ素の定量を行つているが，此のョウ素定量法は從來の方法では稍及複䧴であつたが潰者等の一人中野は Waloszek 等の方法を欧甚し, 此較的簡易に测定し得るに榇つた。

方法 1) 甲狀腺內各ョウ素化合物定量法, 甲狀腺約 $5 \mathrm{~g}$ を $2 \mathrm{~N}-\mathrm{NaOH}$ にて18 20時間水浴上で水解. a) 總

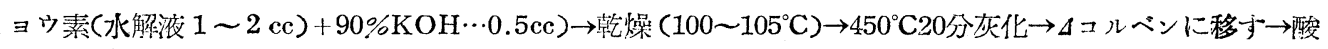
性 $\rightarrow$ 臭素酸化 $\rightarrow$ 臭素除去 $\rightarrow$ ヨ素潵粉液で發色 $\rightarrow$ 比色定量. b)チロキシン(水解液 $3 \mathrm{cc}-5 \mathrm{cc}$ ) +(等量のnブタノール)で 2 回抽出遠心 $\rightarrow($ 上清 $)+(2 \mathrm{~N}-\mathrm{NaOH})$ で洗涤遠心 $\rightarrow$ 多液に就て再度ブタノール抽出 $\rightarrow 2$ 回の 抽出液を合し $\mathrm{KOH}$ を含もルッボ中で水溶上款固以下總ヨード定量に準ず。c)有機ヨウ素:檢體約 $5 \mathrm{~g} を 10 \%$ 
$\mathrm{CCl}_{3} \mathrm{COOH}$ で蛋白沕澱 $\rightarrow$ 水洗 $\rightarrow$ 灰化 $\rightarrow$ 定量.

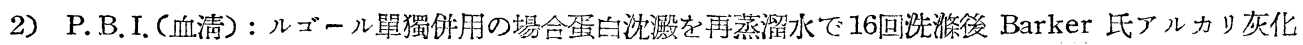
法にて定量. 以上の方法に依つて，メチオデール投與 3 例ルゴール投與 5 例, 兩者の併用源法 5 例について

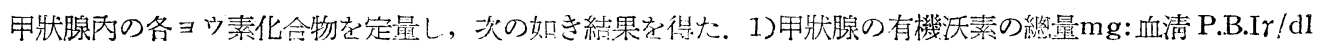

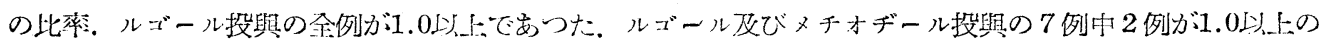

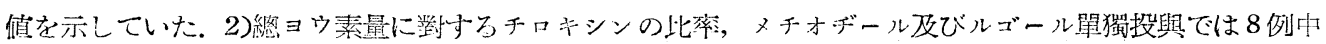
全例が正常值(25\%)以下の值を示していた。 メチオデール及びルゴールの最初からの作用又はメチオデール を短期間投與した後值ちにルゴールを作用したものでは 7例中 3 例が可常值以上であつた.

77. 老人に於ける血清蛋白結合沃度に就て

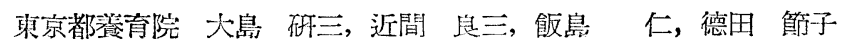

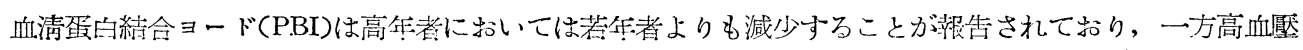
腎者の基礎代謝(BMR)は一般に元淮する場合が多いことが知られている。PBIは甲狀腺機能と密接な關係む

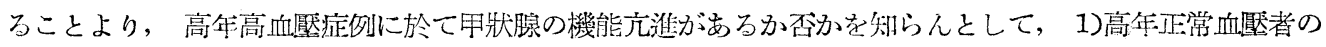

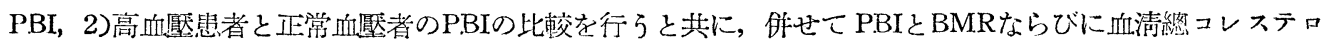
一ル量との比較檢討をも行つた.

方法は1)PBIは Barker のアルカリ灰化法，2)コレステロールは Liebermann-Buchárd の此色法，3)

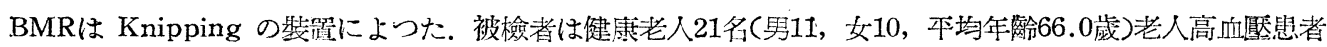

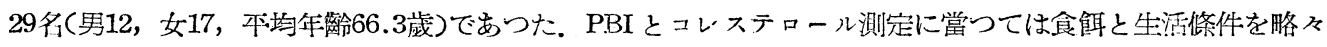
同じく寸る被檢者に就て，朝食前に探血した。

結果は健康老人のPBIは21名平均 $5.54 \mu \mathrm{g} \%(3.22 \sim 9.35 \mu \mathrm{g} \%)$ て大多數は正常範国円にあり, その本均值も

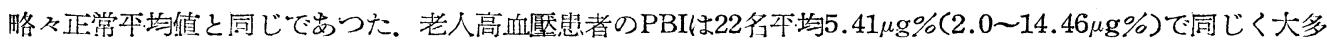
數は正常範圍內にあつた. 健康老人の血清コレステロール量は 21 名平均 $144.5 \mathrm{mg} \%(95.0 \sim 208.0 \mathrm{mg} \%)$ で,

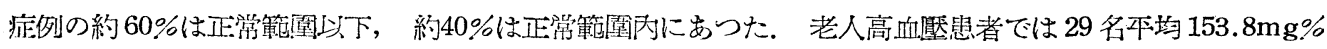

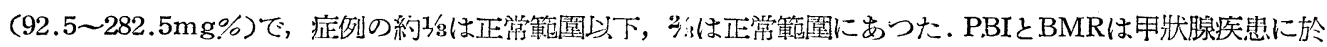
ては略及平行することが知られてるが，老人高血厴喼者においては症例の約牛數はBMR が正常限界以上，

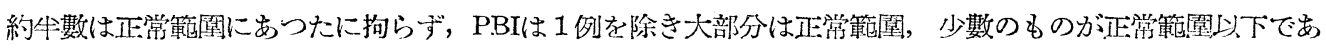

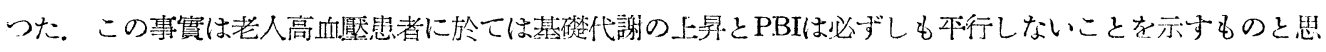
丂.

78. 甲狀腺の沃度代謝に於ける Adrenalin の效果

阪大安田病理 具塚 政美, 版口 昭二, 西村 豊

甲狀腺に對する Adrenalin 投與の影響を I ${ }^{131}$ の uptakeより觀察する篇 Adrenalin 投與方式を變え又

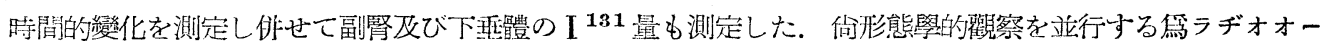
トグラフを篎作した.

實驗には80gr前笋の雄ラッテを用い屡殺前24時間は水のみ與え Adrenalin は千㥉のもの I ${ }^{131}$ は $15 \mu \mathrm{Cを}$

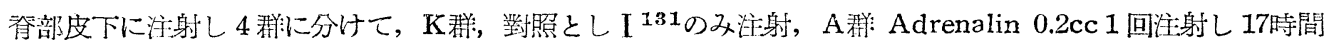

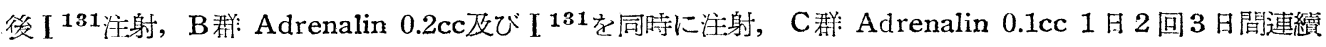
注射後17時間を經て I ${ }^{131}$ を注射し，その後 $4 ， 8 ， 24$ 時間でし臟血液 $0.5 \mathrm{cc}$ ，甲狀腺，下琵體，副腎の重量

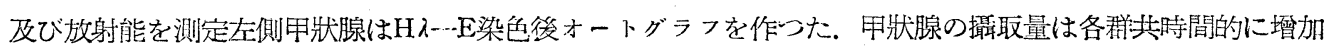
し各時間共Kが最大でPermg3641, 6823, 11339 でCが最小で726, 985, 1153 カウントである. 血中量は 8 時間迄Kが最低であるが24時間になると最高となりCは 4 時間で K に比し僅かに多いが 24 時間になると最低 


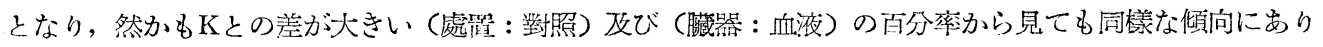
Adrenalin 投與による甲狀腺 I ${ }^{131}$ uptakeの相對的減少は 4 時間に高く以後次第に低下寸ると考えられ組 織的には上皮細胞の高さを墰しているように思われる。 Cannon, Aleshin, Soffer, Botkin 等は Adrenalin 處置により甲狀腺機能立淮を認めているが本賽嬐では I ${ }^{131}$ uptakeの減少を來たした。，B，Bは，Cの中間 にあり副腎下酗體では時間的にもK.A.B.C.間にも一定の傾向は見られない。

以上より Adrenalin 投與によるラッテ甲狀腺の I ${ }^{131}$ の uptake は對照に比し学に減少して居り然かも

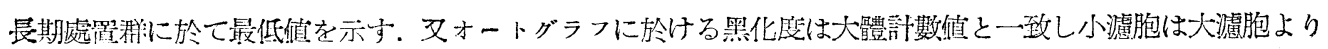
も黑化度が强い，血中量は 4 時間に於て對照㷙に最低值を示し之に反し甲爿腺の量は最高である.

79. 甲狀腺の沃度攝取に關与万㸴究

群駐大七條內科 田中 茂, 福田 信男

人體に於ける甲狀腺の放射性沃度攝取に關与る研究は, 既に前回當敉宝に於て發表して居るが，今回は甲 狀腺の沃度攝取に對する㙨能を分析的定量的に檢蕠する一方法として, 甲狀腺切片を用い，それの沃度攝取 能に及ばす種从な要因の影響に就ての實驗を行つた。實驗方沠としては豚の甲狀腺より切片を作り，預め放 射性沃度の少量を加えたクレブスリンゲル憐酸緩衝淮或いは此に種々なる物質を加えたるのに切片を投入し， 諸種條件下に於ける放射性沃度の攝取量を測定した。現在迄に得られた結果は次の如くである。1)甲狀腺と 他の組織の沃度攝取能との比較：最子生理的に近い條件下に於ては甲狀腺組織は心筋に比し約 60〜600 倍の 沃度攝取を示して居た，2)溫度の影響： $5^{\circ} \mathrm{C}$ に於ける攝取能は $38^{\circ} \mathrm{C} に$ 於ける夫の十分の一に過ぎない，3)

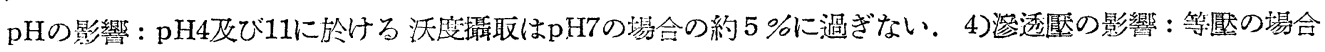

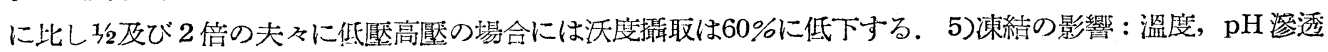

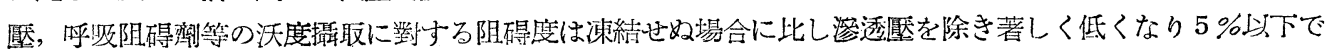
ある切片の胵素消費は凍結に依り約50\%に減少する。6)媒質に附加された沃度化合物の種類の影響：媒質に $10^{-7} \sim 10^{-8} \mathrm{M} \Xi$ ー゙゙インン濃度相當の沃化カリ, 沃度酸カリ, ヂョードチロジンを附加した場合夫タの沃度 攝取に及ぼす影響に於て有意の差は認められない。7)沃度攝取の時間的經過：30分以後急激に堌加し，4時 間以後は平坦になる。 8)一旦取り込まれた沃度の媒質中之の放出に及ぼす各因子の影響：10-5 Mの沃化カリ 溶液中に於て沃度を攝取した切片を $10^{-2} \sim 10^{-6} \mathrm{M} の \mathrm{KI}$ 含むリンゲル氏液中に投入して I ${ }^{131}$ を再放出させ た場合， $10^{-3} \sim 10^{-4} \mathrm{M}$ 於て最も放出が少い.9)放出の時間的經過：60分迄は涑增しそれ以後は平坦になる。

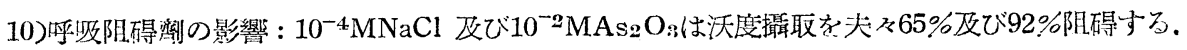

80. バセドウ氏病の術後再發に就て

東宗伊藤病院 伊藤 國彥, 大林 公明, 金地 嘉夫

昭和25年より 3 年間に本院にて施行したバセドウ氏病手術例數は619例である.その中再發を來したもの が88例ある。

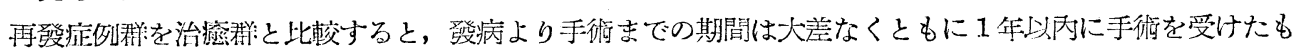
のが過牛數である，術後再發を來す症例は甲狀腺の腫大を發病の副期から自覺しているものに多く，甲狀腺 腫の表面積及び手術切除量より久ると, 再發郡治痖群汇比して甲狀腺腫の大なることが分る. 又, 病理組

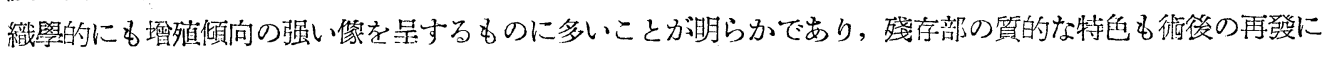

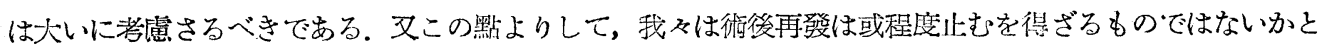
の見解を有している.

手術を施行してから再發を來すに至るまでの期間は大牛が1年牛以队であり，比較的手術後早期より起る

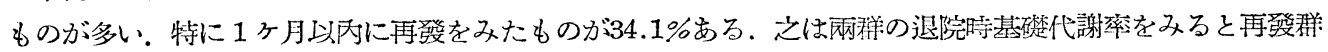
に遥に高值を示导ことによつても分る．からる早期に再發又は再發傾向を表するのに對しては，我及は再發 


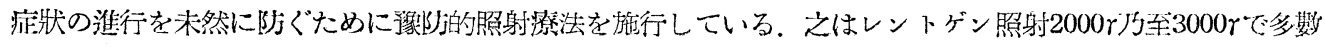
の再發例に對し大なる効果を上げている。

\section{追加}

野口病院 野口秋人

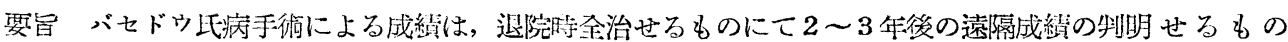

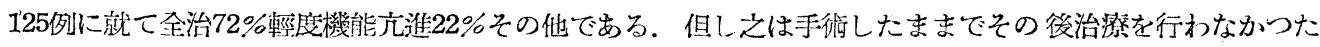

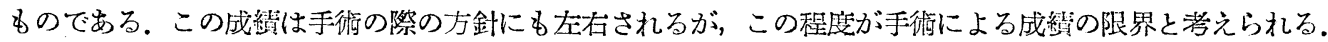
その原因として手石方針の他に甲狀腺以外のホルモンその他の影響が重大なる要素と考えられる。

\section{追加翼問}

身京伊藤病院 伊 藤

尹

要旨 丸田呚授の過分の御言藮に恐縮に存じます，只今野口秋人博士の御話にもある通り如何なる手段を 以てしても再發は避け得ざるものでありましよう，丸田呚授の御言葉通り手術の不愉快さは事に當るものの

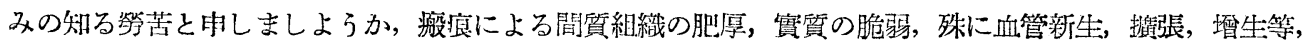
是等を一々最も注意深く，再發組織を殆ど全剔出に近き汽に剔出することに心がけて居ります。

第 1 回手術に際し甲狀腺腫の菱形荘の殘存と又二炏的に左石兩集を時を分けて手術することは, 第一次に 於ける殘存量と第二次手衡時に於ける切除量の加減に多大の国難を覺えますので，出來る文け一次的に兩側 切除を行らことも重要な手術法と考えますが如何にしても再發傾向の大なる例は矢張りその惧れが多いので

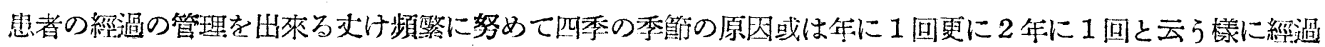

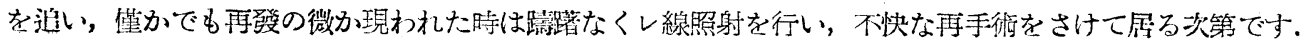

81. 粘液水腫の一例（特にチレオイヂン潦法による肝腎副腎皮質機能觀祭）

東京虙信病院內科本山章

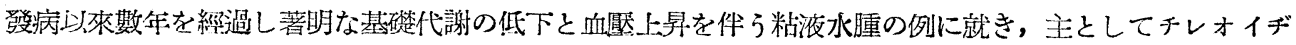

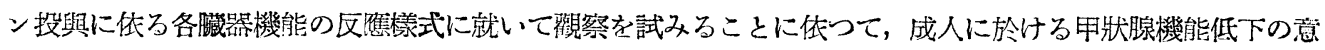
義を考察し樣とした。

㭧者 岡○リ○ 38歲 女子

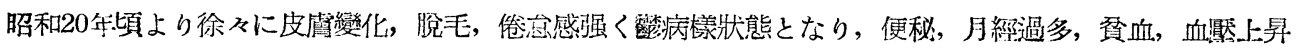
來たし好轉せず來院した。

現症及び臨林檢查所見は典型的な粘液水腫の症候を示したが，骨格正裳，トルコ鞍に異常を認めなかつた。

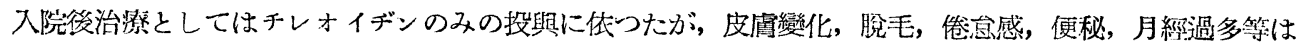
徐从に消失した。

基礎代謝は治潦前 $-51.4 \% ，-33 \%$ であつたがチレオイデン投與に低り速やかに上昇を示し中断後再び

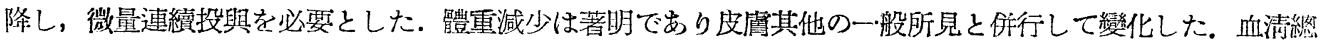

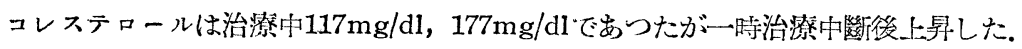

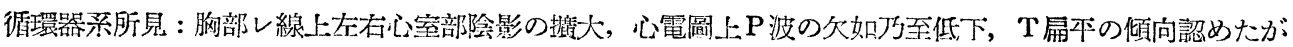

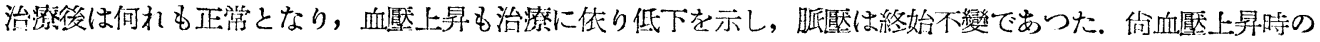

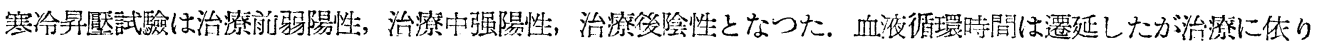
略々正常徝を示した，循環血量は治潦中增加した。

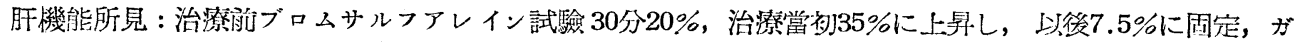
ラクトーゼ負荷試驗は治潦龍 $1.8 \mathrm{~g}$, 治潦後 $4.4 \mathrm{~g}$ と陽轉した。

掔機能所見 : 治源前, 標淮尿素クリアランス $36 \%$, 治潦後 $63.3 \%$ となり, 水試驗に於ける濃縮㙨能低下も 回復した.

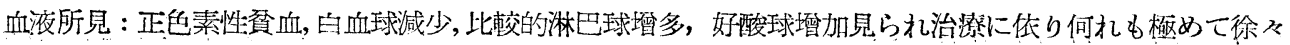


ではあるが正常偵に近ういた。

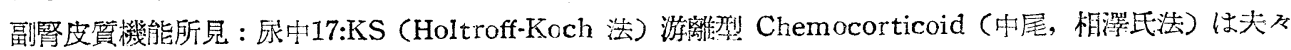
$1.0 \mathrm{mg} / \mathrm{day}, 3.7 \mathrm{mg} / \mathrm{day}$ と減少を示したが治滰に依り夫々正学值となつた。血清 $\mathrm{Na}, \mathrm{Cl}$ は正常より僅かに 增加，治潦後正常，血清Kは正常よりや〉增加した，血糖值は略队正常。(綃)甲狀腺機能低下の際のチレオ

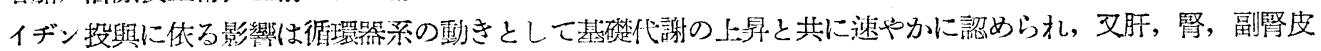
質機能の變化を俳うに至るが，血液所見の變化には可成りの期間を要するものと考えられる，倘ガラクトー ゼ負荷試驗の陽轉はチレオイヂン投㠘に依るものかとも教えられるが，今笋の檢討に俟ちたい。

82. 精种薄弱兒に見られた潜在性粘液水腫の治源効果

東邦大小兒科 久保 政次, 島田 達雄

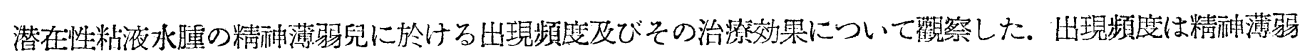

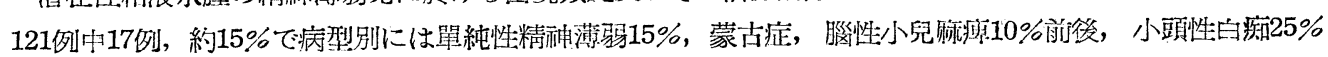

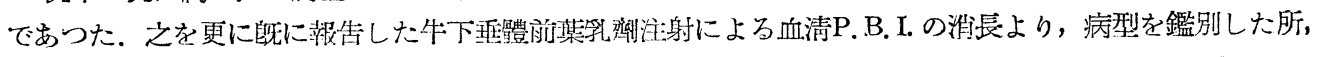

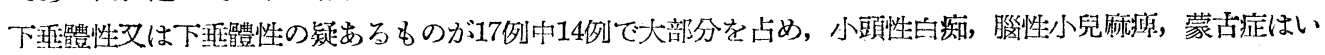

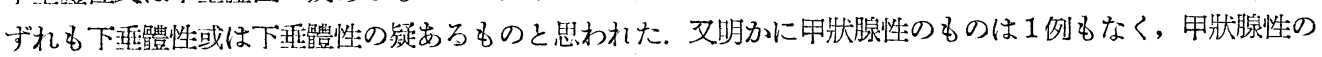
疑めるものは槿か 3 例で此等は全て單純性精神薄弱に屬するものであつた，次に明かに下开體性のもの 4 例，

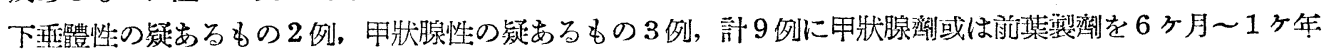
間與之, 治潦効果を觀察した所, 身體症候では 9 例中 6 例に軟部症候及び一般症候の好轉も見, 化骨狀態は 6 例中 1 例に著明な改善を，3 例に輕度の改善を認めた. 又治潦終了時に於ける生化學的所見は, 9 例中 8 例に血清 P.B. I. 值の墰加, 血清コレステロールの減少を認め, 6 例に血清總蛋白量の減少 8 例に血糖量の 增加を見た。，その他細胞外水分量, B.M.R. E.K.G. で異掌所見を示すものは, 何水もその正常化が認めら

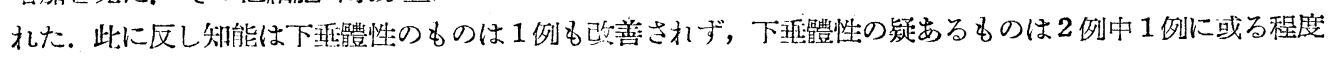

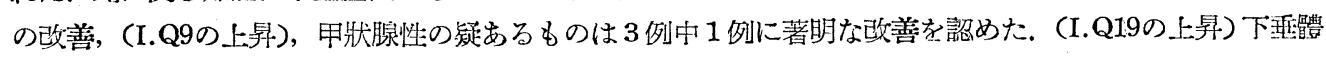
性の甲狀腺㙨能減退は精神薄弱の原因ではなく，むしろ結果であると思われるので治療効果の期待出來ない のは當然である。倘興制のあることは腦波所見と治潦効果との關係であつて, 腦波に $\delta$ 波領域の出現著明な 異常腦波を示すものは知能が全く改善されず, 腦波所見の正常なものにだけ知能の改善が認められたことで 岕る。

83. 植物性血糖降下物質に關与る研究 (第 3 郝)

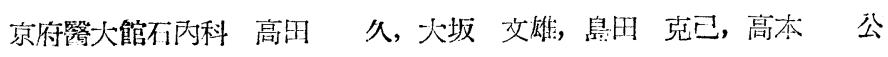

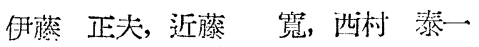

（1）有効物質の分離に關与る基不楚的檢案 透析及びアルコール虎理試驗に依り有効物質は高分子物質にし て, 蛋白, 多糖類, ポリベプタイド等の範暚に屬するものと考えられ，可及的純粹に分離せんと努力中であ ๖.

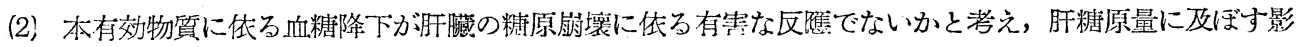
響を檢索した，其結果本有効物質は肝糖原量を減少せしめず却つて肝瞞の糖原合成能及び保持能を增强せし むる傾向を認めた。

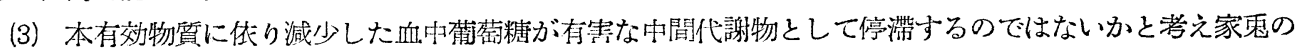

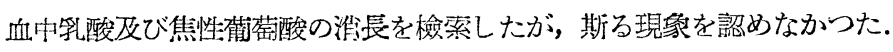

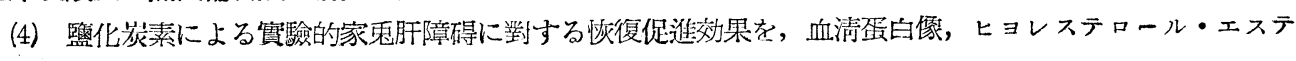
ル此等より確認し得た.

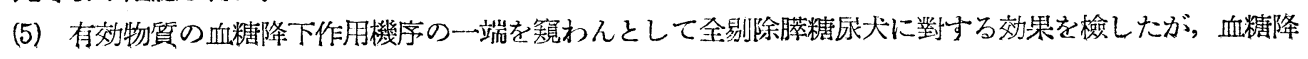


下作用を認めた。一時的にせよインシュリンを代償するためであるか否かは不明である。

\section{4. 糖尿病の沃度代謝}

京府竪大舘不內科 伶藤 東達, 小池 克己

甲狀腺と糖尿病とは相當密接な關係にあることは從來諸家により認められて属る所であります．而して甲 狀腺機能制定上最も有力な指標としては S. B. Barker により提昌せられた蛋白結合沃度が今日一般に確認 される樣になつて居ります。

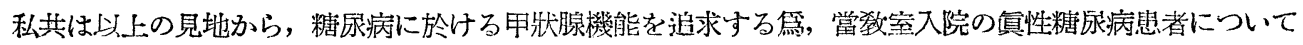
蛋白結合沃度(PBI)を測定し，興味ある所見を得ました。

郎七13例中血糖值最高 $375 \mathrm{mg} / \mathrm{d} 1$ 最低 $125 \mathrm{mg} / \mathrm{dl}$ であつたがP.BIは最高 $14 \mathrm{r} / \mathrm{d} 1$ 最低 $5 \mathrm{r} / \mathrm{dl}$ で本均 $10.0 \mathrm{r} / \mathrm{dl}$ であ つて別に實驗放しました健康者平均值7.4r/dnに比して若干高值を取つて居ります遊離沃度は最高10r/d1最低

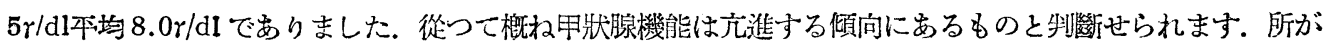
血糖との間には密接な閣係は認められませんでした.

この事實は Houssay 等の所䜊 “thpoid-diabetes”說を裏付けるるのと思われます. 份 Insalin との關 係，實驗的糖尿病に於ける甲狀腺の態度については引續き追求し後月報告する豫定で居ります。

\section{5. 糖筫代謝の柔続發生學的研究}

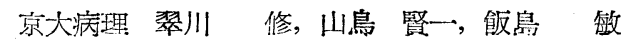

膵䧕ラ上鳥を比較解剖學的に調べると, 各種動物のラ氏島は何れも二種以上の細胞から成立つている. 然

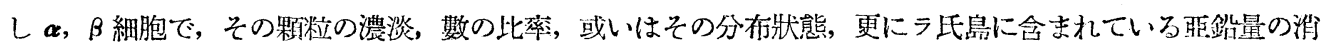
長は著しく動物種によつて異る. それらの綜合は次の如くである。

1） Insulin 之關係すると思われる顆粒の濃淡は必ずしもラ氏島の亚鉆樣物質の洕長とは一致しない。

2) Alloxan による $\beta$ 細胞障碍の程度はそれに含まれている亞鍇量と凡そ平行するが舀の如く互鉛量が多 いのにも拘らず糖尿病を特こさないのもある。

3）モルモット, 幼若鬼, 或は鴙の如く Alloxan により恒久性糖尿病を發生しないものは何れもその $\alpha$ 細胞數か、多い.

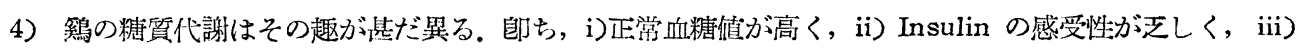
膵を全摘しても糖辰病を起さず，iv）Alloxanを與えても血糖值は不變であり，血中の尿酸值が著しく堌量 する．更にv)ラ氏島で細胞より $\alpha$ 細胞の方が櫢が多い。この鴙に Dithizone を投與すると，

1）血中尿酸は，特に大量投與の場合に著しく增(正常の10培以上)小量注射の場合には一過性に增す。

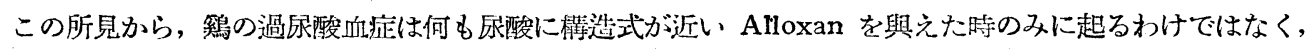
蛋白質の分解が Alloxan Dithizine 等の有毒物質の投與のために高まつて, その結果 Endroprodukt (終 末代謝㡾物)である尿酸が血中に增えたのに過ぎないことを示している.

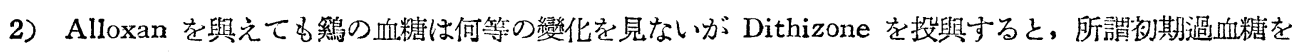
見ることなく 1 時間目から primar に低血糖を示す，その後一時血糖が上舁することあるも直りに降下し 決して糖尿病を發症しない，この現桑は非常に多くの問題を含んでいる樣に考えられるが, 詳細は改めて後 日表する福定である.

86. 膵淋巴管結紮家鬼の糖代謝に關する研究 (第 1 報)

京府醫大川井內科 葛谷 覺元, 武田 守

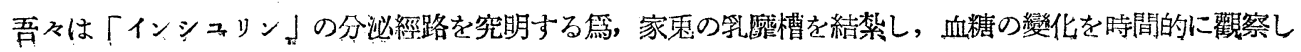


た，先ず結禁について，膵淋巴管を單獨に結紮するのは到底不可能な事であるから，乳魔槽を第十二肋胃下

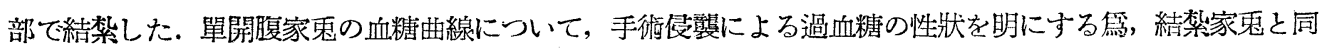
條件で開嗄し血糖を觀祭した所，過血糖の程度は異るが略及同樣な曲線を畫き，術後 3 時間で稍々下降に向 らが，術前值には回復せずその間血糖の大きな變動を見ない，結禁家乘の血糖曲線について，手術後過血糖 を示したるのが全例に历び，30分乃至 1 時間後に著明に一旦下降し，殆んど術前值迄下降するるのもある. 次で何れも再び著しく上昇し， 3 時間乃至 4 時間で術前值に回復する樣である. 毁ち對照と異る點は, 術後 單時間で下降し，再び上昇する點である.

考察「インシリン」の分泌經路として淋巴路を對照とした吾及の㸴究では, 從來の血行性經路の他に, 淋 巴性經路をも考えなけ扎ばならない。結禁家鬼で術後 1 時間に見る血䌅降下については手術侵襲による過血 糖の自然的消退とは考えられない. 若し「インシュリン」の分泌經路として淋巴路が蛗與せず總て血行性で あるならば結紮を行つても單開腹家鬼と同樣の血糖曲線を呈すべき筈である. 正常時には「インシュリン」

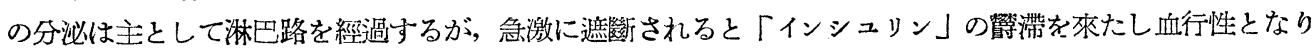
血糖は下降寸るのであろう，血糖降下によつて「インシュッン」の追加的分必は減退し，手術侵琵に依る血 糖上舁作用が顯著な䉆再び上昇し, 手術侵襲に上る影響の消退につれて血行性に「インシュリン」が入り,

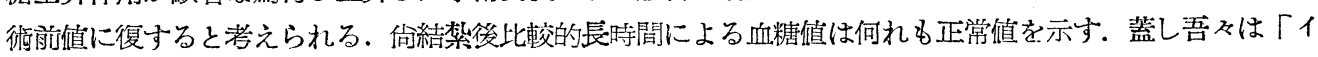
ンシュリン」は正常時淋巴路を經て分泌されるものである事を血糖の變化により證明し得たと信ず。

87. 糖尿病及び各種矣患に於ける Hagedorn-Jensen 氏法と Somogyi 氏法による血糖值の比較

$$
\begin{aligned}
& \text { 東京濟生中央病院 慶大內科 北村 信一，责柳 忠夫，田中 剛二，片岡 邦三 } \\
& \text { 仁木 豊, 鍋島 康嘱, 山口 與一, 堀內 光 }
\end{aligned}
$$

（1）糖尿病21例，肝疾患12例を中心に，空腹時，葡萄糖 $30 \mathrm{~g}$ 經口投與時及びインシニソン負荷時に於ける 血糖值を Somogyi 氏洗及び Hagedorn-Jensen 氏法により同時に測定し, 兩者を比較對照すると, 空腹

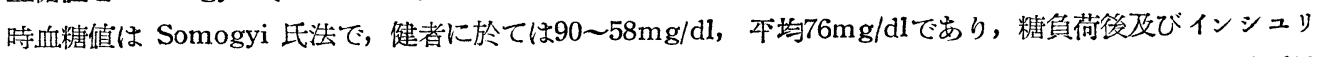
ン負荷後の血糖曲線は大體に於て本行する關係が見られる. 又 Himsworth 法によるインシュリン感受性 $\mathrm{I} / \mathrm{G}$, は 2 つ方洗の值の間に相關關係が見られる. 故に Hagedorn-Jensen 法は真糖值との間に一定の差 あることを考慮さえすれば，血糖曲線解釋上差支えないと考えられる.

（2）次に兩方法による血糖值の差を非楼還元物質と考えて，その消長につき觀察してみた．空腹時非楉還 元物質の平均值は健者, 糖尿病, 䀒疾患では何れも $22 \mathrm{mg} / \mathrm{dl}$ であつたが, その分布範園は健者で比較的狹く,

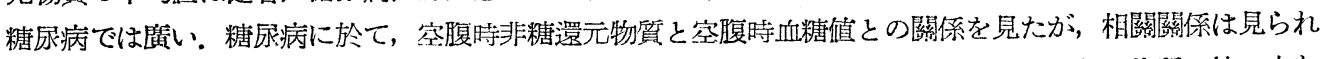
ない. 又肝機能檢查成績との關係は, 肝疾患に於て血清ビリルビン㥀の高いものに非糖還元物質の值の大な る傾向があるが，その他の檢查とは特別の關係はない。

糖負荷後の非楉還元物質の動きを見ると, 糖尿病, 肝硬變症の一部に於て變動の大なる例があつた。糖尿 病に於ては，輕症か又は發病より10年以上も經つて，ある代謝位相に於て釣合いを保つている例で，糖負 情後非糖還元物質の變動は殆んどないが，發病後 5 年以內で，この釣合の光成されていない例では，血糖值 の變動も大であると共に非糖還元物質の變動も大である. 而も實驗的にインシュリン静注及び葡萄糖溶液静 注により急激に血䌅を下降又は上昇せしめると, 非糖還元物質の下降, 上率が見られたことより, 非糖還元 物質の動きは，血糖の急激な變動と何等加の關聯を持つるのと見られ，糖尿病のからる爿態に於ては，單に Hagedorn-Jensen 法による血糖曲線の解釋には注意を要すると考えられる.

\section{質問} 京醫大第一内科大坂 文 雄

Hagedorn-Jensen 氏法と Somogyi 法の測定值の差に就いて Somogyi 法にて低血糖 $4 \mathrm{mg} / \mathrm{dl}$ の時に臨 床症狀は如何かし. たか，その時の Hagmdorn-Jensen 氏法測定值との差は如何が御考えでしたか。 
蛊問

東京都濟生會中央病院 北 村 信 一

第 1 の質問に對する返答 インシュリン 4 單位を靜注した時, 前皆睡狀態でありながら血糖值が Somogyi 法で $4 \mathrm{mg} / \mathrm{dl}$ を示したことは，方法そのものがさ $20 \mathrm{mg} / \mathrm{dl}$ の誤差を有しているから，必ずしも不思議とは思

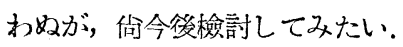

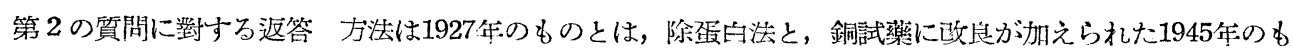
のである。

質問 神戶䂑大竹 田 正次

Somogyi 糖定量法の最近の方法に未だ檢討していませんが，以解の方法と Hagedorn 法とを比較した

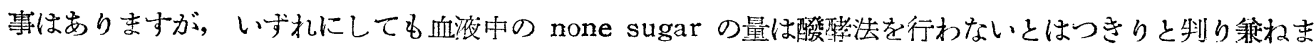

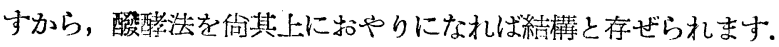

88. Staub-Effekt の本態に關する實驗的矿究

神戶大竹田內科 中野 恭本, 梶山 程人

Staub-Effekt (S-Eと略) の本態に就て考察せんとすれば先ず負徛糖の體內に於ける運命に就て考察する

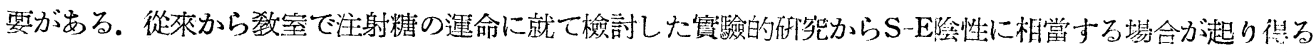
可能性を考えると，

1. 旰, 筋に於ける【糖負㑸後の啸收㞣能低下.

2. 肝, 筋での糖原造成が不艮.

3. 早, 筋での糖原外の非還元物質への糖化不豦.

4. 腎よりの糖排泄が少い場合.

5. 糖の分解不良.

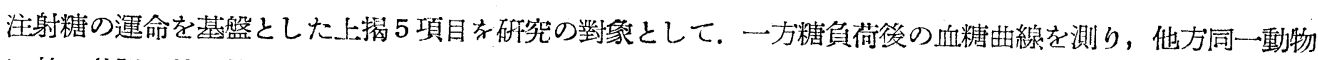

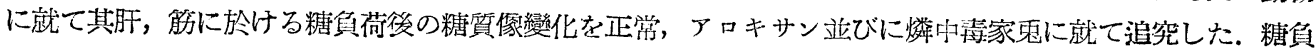

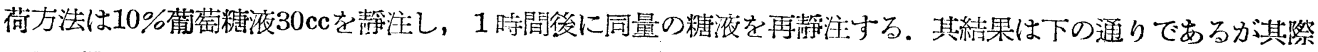
S-Eは燐家身で著明陰性,「ア家怂で陽性であつた。

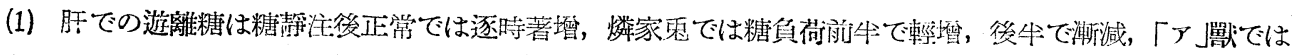
糖㲗注後不變若くは後牛で增加.

(2) 肝での糖原造成は正常で最良，燐，「ア」獸では變化が少い。

(3) 肝での糖原外他種糖例之ば水解糖への轉化は三場合相違が無い。

(4) 腎からの糖排洲は「ア」家宦最大(50\%前後), 正常及び燐家雨では輕少(15\%以下).

(5) 筇糖質像變化は輕度で-Eに影響を及ぼす程度で潕い。

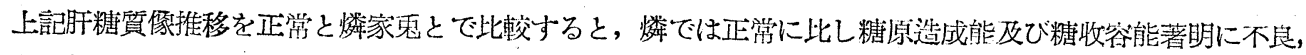

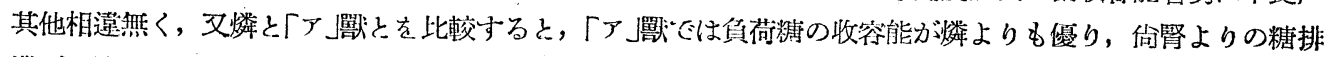

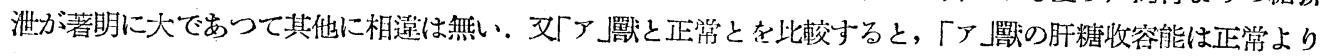
も著小で, 糖原造成も不良であるが，腎からの糖排毗が著大である.

以上から上記の場合に就てS-Eの上に最重要な關係学持つ因子を考えると肝での糖收容能と糖原造成能及 び腎からの糖排洲如何と云う三點に歸する。

\section{質問}

身大冲中內科 葛谷信 真

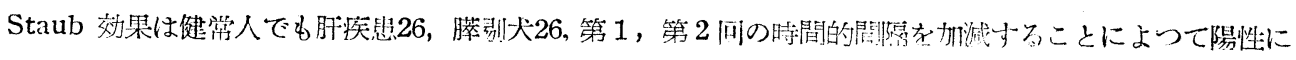


も陰性にもなるものであります，從つて Staub 効䒚の本態機構の解明にはこの時間と密度な關係ある因子 をおしめし願い度と思いますが，その邊の關係は如何でせ弓か。

89. 青学脈內葡萄糖二重負荷試驗の單一負街血糖曲線による分析とその意義

身北大黑川內科 後 藤 由 夫

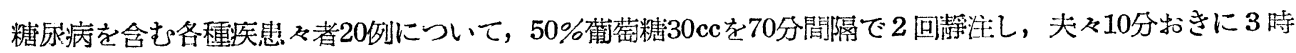
間にわたつて血糖を测定した。更に同一患者について玍日，單一負荷を行い，空腹時血糖值よりの血糖の增 加量をその血糖曲線の上に 70 分目を基點として順次に加えて推定二重負荷血糖曲線を描き，これと前の實際 に行つた二重負荷曲線とを比較してみた，それによると网畨は大體一致し，本質的な差異は認められない。

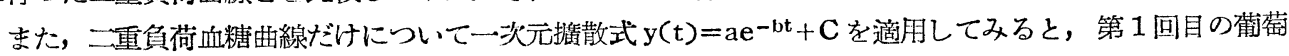
糖注射による各時焛の血糖增加量は $\mathrm{e}^{-\mathrm{bt}}+\mathrm{C}-\mathrm{F}$ ( F は注射前血糖值) となる。炏に第 1 回淮射 70 分以後の 70 分を起點と寸る第 1 回目の血糖曲線は

$\mathrm{a} \mathrm{e}^{-\mathrm{b}(\mathrm{n}+\mathrm{t})}+\mathrm{C}$ となる(70分であるから $\mathrm{n}=7$ ) 從つて 2 回目の蒇萄糖注射による血糖曲線はこの 2 つ和と なり結局

$$
\mathrm{a}\left(1+\mathrm{e}^{-\mathrm{bn}}\right) \mathrm{e}^{-\mathrm{bt}}+2 \mathrm{c}-\mathrm{F}
$$

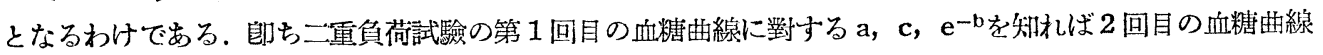
に對する $a ， c ， e^{-b}$ は答易に計算出來ることになる。この數犆と實際に第 2 回目の曲線について得た數值と を比較したがやはり兩者はよく一致した。

これらの簀驗成續から，Staub 効果はその最高值だけを比較するときは勿諞のこと，血糖下降曲線につ いて檢討してみても單一負喵血糖曲線の單なる和として充分說明出來る樣に思われる，從つて，糖同化機能 試驗として, 粠の二重負荷試驗を行らことはかえつて制定を複雜にするばかりで利點はなく, 單一負荷試驗 で充分糖同化機能を制定しらるるのと考えられる。

\section{犋問}

東大冲中內科 小坂 樹 德

極めて興味深い成績と思われます，從來私共は過血糖による追加的インシュリン分泌に對する疑義を主張 して來ましたが，只今の御報告もこの私共の主張を裏書された樣な知見と考え得られます。唯こつで問題に なりますのは, 第 1 回の糖摄取により生體の糖同化能は增强されるるのとする從來の知見に對してこれを否 定する成績とも考えられますが，この點について御意見を給りたい。

答

後檫由头

この研究は血糖曲線げけについて铪じたものであつて, 勿論インスッンの遄剩分泌の有無, 糖の分解過程

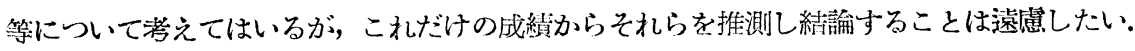

追加

黑川內科 齊 藤 澾 雄

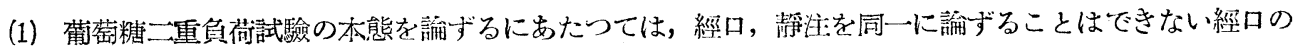
場合 Staub 効果を 2 回の山の最高值の此較と解釋する限り，計算二重負荷曲線が，實測のそれと一致する

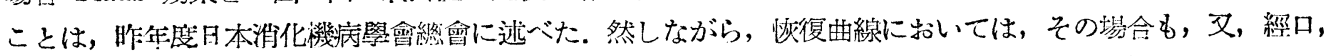

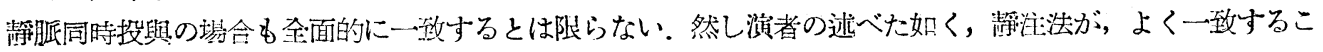
とから考えて，からる恢復曲線の相違に對しては，腸管よりの吸收が，かなり重要なる因子として關係する ものと想像している。

（2）我及としては，計算式を先につくつて，之に實驗成續を符合せしめたものでなく，むしろ，實測成絙

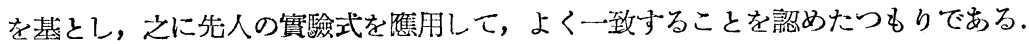

(3) 肝障㖊時の Staub 効果に關しては, さきに, 昭和13年, 教室寺田が, 家鬼において, 燐, クロロホ 


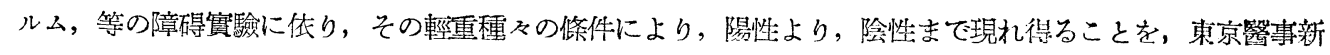
誌上に發表しあり。

犋問京府大舘石內科高田 久

肝障碍時には如何なる血糖曲線を示すか， 2 回目の糖負荷に對して肝臟の自律的の糖調簛機能を考えられ たか。

追加

大挭大學安田病理 永 非清 和

血糖值は Stadie (1954, Physiological Review) の指摘する四段階の他, 中村氏も血糖は Phosphorylase, Phosphoglucomutase, Phosphatase 等の綜合作用によると云う. 例えば Glycogen と Glucose-1-phos phate の間では約 $20: 80$ 位で本衡に達するのであつて, 1 回目の Glucose 注射により之等の醳素柔が動く から無影響であるとは考えにくい。

90. 血糖調節機轉に關与る破究

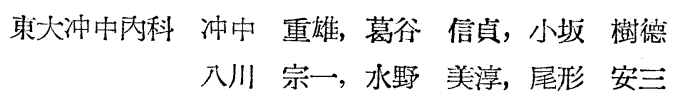

第23回本總會に Grafe \& Meythaler の實驗結果は過血糖によるインシュリン分必を以て說眀すること に疑義あることを報告したが，今回更に檢討を加え，インシュリン作用の Lag，血糖上䒜量の他，注射前值 へのもどり時間について觀察した，前回の監モヒに變え，今回は10\%オーロパンッーダで嘛醉し，實驗動物 は10kg前後の犬24匹で前回々前樣50\%ブドー糖 $6 \mathrm{cc}$ を10分間に各種血管に注入した。

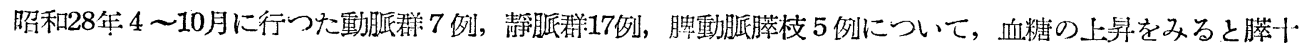

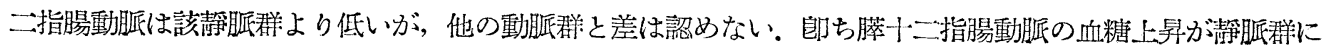

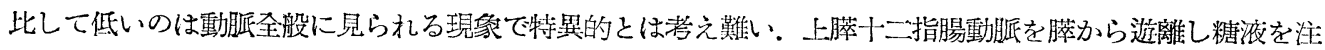

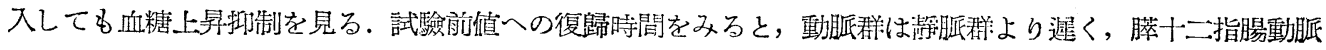

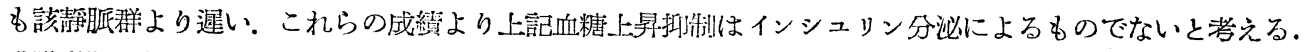

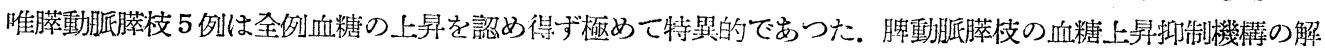

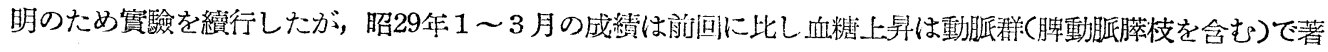

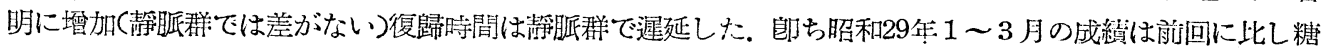
同化能の低下を示していたその原因について若下の檢討を加えたが現在のところ季䬦的變動によるものでは ないかと洘えている。

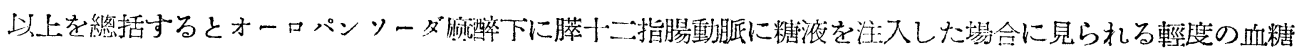

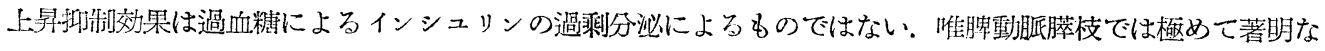

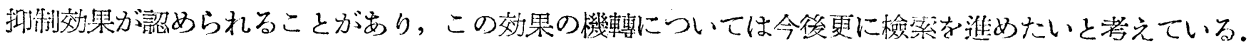

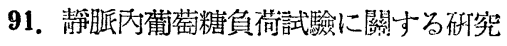

$$
\text { 儿大楠內科平四孛正 }
$$

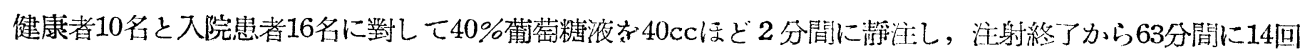
の探血を行い, Hagenorn-Jensen 氏法により血糖を測定した。向, 特に最初の 5 分間は 1 分每に採血した。 その結果注射終了の1分後から一定時間內に於て, 血糖值yは炏の式によつて表わし得る事が制つた。刨ち， $\mathrm{y}=\mathrm{C}_{1} \mathrm{e}^{-\lambda 1 \mathrm{t}}+\mathrm{C}_{2} \mathrm{e}^{-\lambda 2 \mathrm{t}}$, 但し $\mathrm{e}^{-\lambda} \mathrm{I}<\mathrm{e}^{-\lambda 2}, \mathrm{t}$ は時間 $\mathrm{C}_{1}, \mathrm{C}_{2}, \lambda_{1}, \lambda_{2}$ は常數, $\mathrm{e}$ は自然對數の底である。この

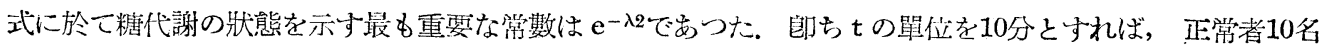

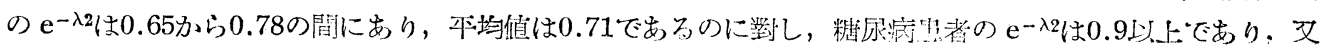




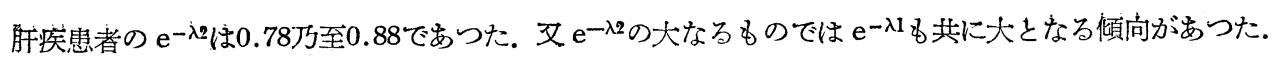

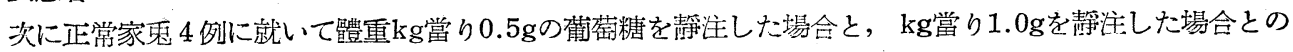
血糖值を上述の方法によつて測定したが，この際もこの式は適合した，その結果， $\mathrm{e}^{-\lambda 2}$ は負何する葡萄糖量 の大小によつては變化なく，その本均值は各々0.89であつたが，その他の $\mathrm{c}_{1}, \mathrm{e}^{-\lambda 1}, \mathrm{c}_{2}$ の 3 者は $\mathrm{kg}$ 當り

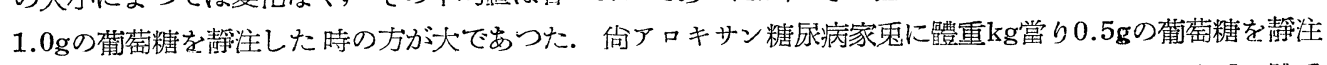

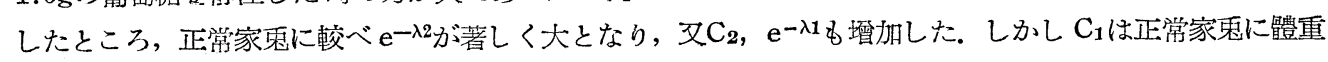

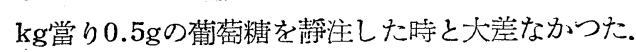

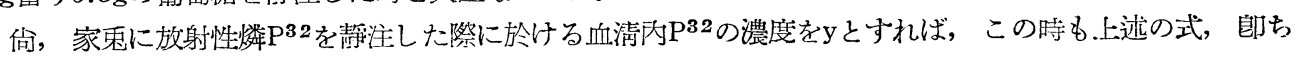

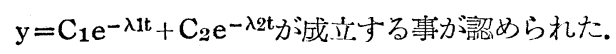

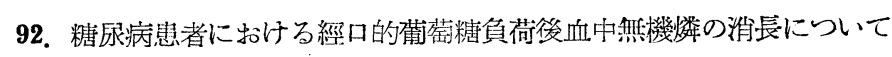

東大黑川內科 齊藤 達雄, 清野 耕吾, 伊藤伊三雄

糖中間代謝に扣ける血中無機燐について，最近注目されておるが，吾及は糖尿病における糖代謝窅知の一 助として, 糖尿病患者その他 41 例に於いて, 經口的に葡萄糖 $50 \mathrm{~g}$ 水 $250 \mathrm{cc} に$ 溶解して投與し, 空腹時值立 びに負渮後30分每， 3 時間に亘り，血中無機燐及び血糖值を檢查した．無機燐值測定は，光電比色計による Fiske \& Subba Row 法(Aminonaphthol Sulfonic Acid 法)によつた。 その結果, 空腹時無機燐は 3 例 を除いて全例, 正常值 $(3.0 \sim 4.7 \mathrm{mg} \%)$ を示し, 空腹時值については, 特に糖尿病型及び健康者との間に著 明な差異は認められない樣に思われたが，葡萄糖負荷後血中無㙨燐淮度曲線を血楉值曲線と共に考察するに， 負荷後の無機燐減少量は. 糖尿病21例において, いずれ子健康體に較へ僅少であることを知つた。刨ち, 健 康體 5 例では, 負荷後大體 1 時間半で最低值となり，その最大減少量は $0.75 \sim 1.25 \mathrm{mg} \%$, 本均 $0.95 \mathrm{mg} \%$ で，血糖の恢復と共に，大體 3 時間で殆んど元に炏復することを知つた。これに比して，當㸚窒分類による 第 I 型糖尿病11例では，靑銅色糖尿病を除く全例が，大體 2 時間〜 2 時間牛で最低值を示し，その減少量は

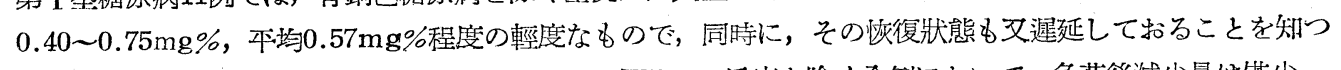
た。更に, 第 II型糖尿病10例では Kimmel-Stiel-Wilson 氏病を除く全例において，負何後減少量は僅少， 若しくは，殆んど變動を示さず，最大減少量 0.05 0.40mg\%, 本均 $0.22 \mathrm{mg} \%$ であつた. 即ち, 糖尿病で は, 糖投與が燐代謝に影響が少いため, 葡萄糖負荷後血中無烧燐の消長から, 糖尿病型及び健康體を含む非 糖尿病性疾患との間に, 明膫な差異のあらわれることを知つた。

93. 血糖の神經體液性調節に關する研究 (第 1 報)

浴風會 (䣽長尼子富士郎) 村 地 悌 二

オーロパンソーダ靜注が其自體血栯值に影響を及ぼさない事を確め，本劑を用いて 3 匹の犬につき，20\% ブドー糖20cc及びインシュリン體重每䣶當 0.2 單位靜注後の血糖曲線に及ぼす麻醉劑の影響を觀察した。

充分深い腹醉を保たせると, 麻醉下に於ては, ブドー糖箐注後の食餌性低血糖が强く現われ，インシュリ 二低血糖後の急激な初期血糖上昇が 5 - 10分退れて現われる傾向が見られる.

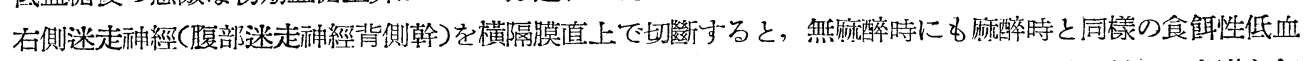
糖か現われ, 兩側切斷でこの傾向が更に强く見られた. 一方インシュリン静注後の血糖曲線は, 急激な初

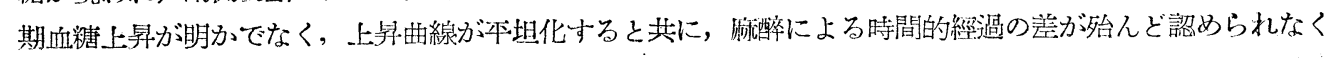
なつた.

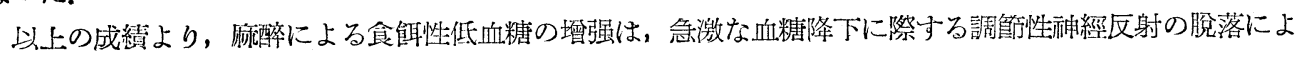

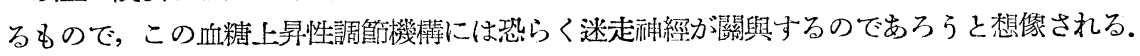

私は昭和 26 年度本總會に趠膸糖刺に㽧する發表を行つた際, 迷走神經背側核の或る部位の刺战が血糖を上 舁させると推定される成續を報告したが，今回の實驗成續は，迷走种經中に，何等かの意味に於ける血糖上 
昇性㙨能の存在を瑔想させるもので，前回の報告と照合し桠めて興味ある事實と考えられる.

94. 肝代謝機能より見たラ氏島 $\alpha$ 細胞性過血栯因子に就て (續郝)

阪大第二病理 （指導 安田龍夫）桂

億

最近ラ氏島 $\boldsymbol{\alpha}$ 細胞性過血糖發現に就て種々の論議がなされて居る。私は牛懐よりの抽出 (Stewart \& Roitman 1953) 瀂類のラ氏島よりの分離 (Staub 1953), 等を試みたが, Eli Lilly Co.よりのH-GFを用

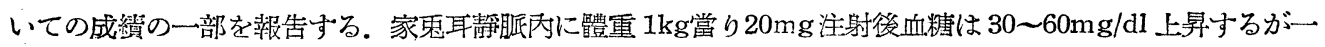
週性で，豫め Insulin で處置した郡でも血糖の上昇を見た。6 日及び13日間 ( 1 日1回)連續注射群の肝で は組織呼吸の值は正常に比し牛減し, Mitochondria 隹も略々平行し, HX-E染色で細胞內に空胞化が見ら れ，其はSudan で茶褐色に染り，Nilblau で青染し，Smith では不染であつた，PAS 反潐は注射後20分 で肝小莧邊緣帶に著減するが連續注射では對照と著變なく，アルカリ性フオスフアターゼは連續注射で䅢及 增加, 核酸及び酸性フォスフアターゼ染色は成續不定で, ラ氏島では Gomori 染色で $\alpha$ 細胞にフロキシン 顆粒猪溜の傾向强く $\beta$ 細胞は核の濃縮めり，一部 Degranulation を認めた。向 in vitro で Hexokinase に對する作用を Insulin と對比してWarburg 檢堅法にて檢索した。.上上總括すると，1) Green 等の云う Cyclophorase-gel が Mitochondria であると云う說からHGF注射のQo2值に及ぼす影響と Mitochondria の戀化が一致し細胞活性の著明な低下を認めた。2)肝糖原の減少は邊緣帶に著明で脂肪恐らくは脂肪酸の增 加と對比して興味深い. 3) Elman, Butcher 等の云う Lipotropic-factor はHGFには餘り關係しない㨾に 思われる. 4) Hexokinase に對するH-GFの態度はInsulin と拮抗的で0.002mg以上で完全に阻止作用が見 られ特異的であるが, Haft \& Mirsky 等の暗示している點も考虑されねね゙ならない，5）５氏島の Gomori 氏法による $\alpha$ 及び $\beta$ 細胞の變化及び肝糖原の狀熊上りすると, Homeostasis の機序が强く働いてて居り, 高位

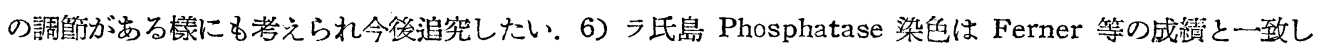
なかつた，最後に本賽驗逐行に當り淸水擎樂及び Eli. Lilly. CO. Kirtley 氏に多大の援助を賜り深く感謝 する.

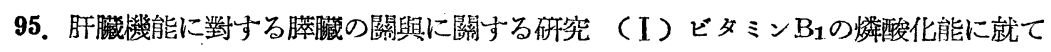

名大分院內科 山田 弘三，榬田 耕治

肝臟の諸機能に對する膵瀻の關與に關与る研究は多く, 殊に糖代謝に就ては「インシュリン」との關連に 於て重要なる業積が多い，我ふは肝臓の諸物質代謝機能の多くのものに就て膵臟の關與の有無, 意義及びそ の機序等に關して一連の研究を續行中であるが，今回はビタミン $\mathrm{B}_{1}$ に對する肝臟の附燐能に對する膵㖑の 關與に就て報告する.

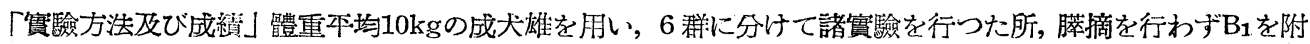

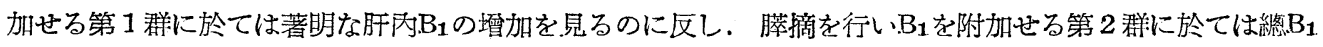
量の增加は僅少であり遊離型の增加は見るも絓合型は減少を示している. 更に第 3 群に示すが如く膵摘出に

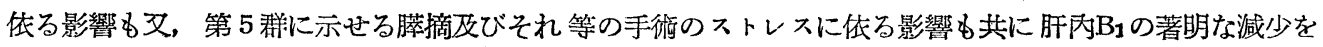

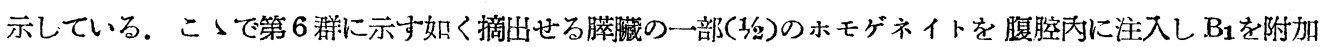

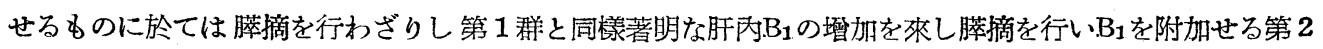
群とは明らかにその增加に於て差の有る事實を認め得た。な持第 7 群に於て膵摘を行いインシュリンを注射

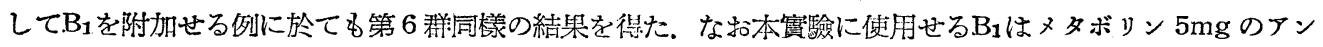

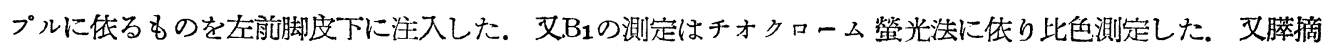
は頭部を殘して呺の亞全摘出を行つた。

「結論」これらの事賽に依り膵摘出犬に投與せる $\mathrm{B}_{1}$ の燐酸化は非摘出犬のそれに此較して甚だしく障碍さ れる事を確め得た。こっに附加された $B_{1}$ の肝臟の附燐能に對しての膵臟の關與の重要性が眀らかに成つた 
が，インシュリンとの關連に於て其の影響をも確に認めうるがこれのみでなく, 更にインシュリン以外の膵 閥內諸物質の影響に依る所もあるのではないかと考えられ目下研究續行中である.

追加

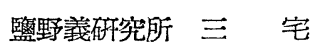
有

私共は肝に於ける $\mathrm{B}_{1}$ の代謝には腦下垂體副腎系が密接な關係を持つていることをラッテを用いて觀察し

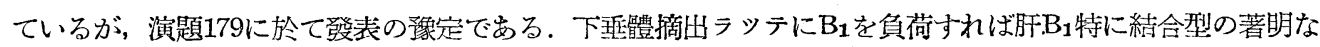
增加を示し，この際 $\mathrm{ACTH}$ の投與は結合型B 1 增加の現橡を抑制することをみている。インシュリン或は膵

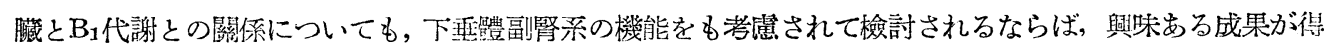
られるのではないか。

96. 糖尿病に見られる腎臟障碍について

國立東京第一病院內科 日野 佳弘, 中村なを急

近來歐米に於ては Kimmelstiel, Wilson 以來糖尿病患者の腎㺂障碍が注目されてきている。吾々も昨年 度の本學會に於て本問題に關与る続計，臨㦿について報告したが，更に症例を䨘ね過去 3 年間本院を訪れた 糖尿病患者について調查研究した結果を報告する.

糖尿病患者中には一過性の蛋白尿を伴うもの(A群) と持續性の蛋白尿及び沘查に腎炎樣の所見を有するも の(B群)がある。

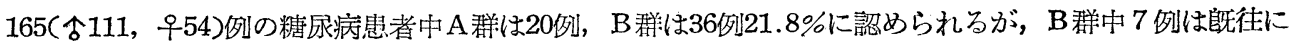

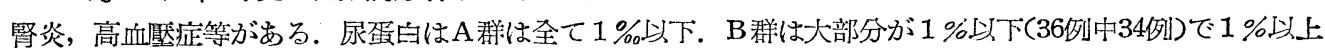
は2 例. 以下B群のみについてのべるならば，㴤查は慢性腎炎樣で全例に少數の赤血球を認め，其他白血球，

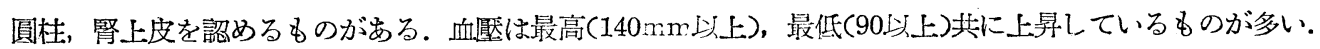
朝食前空腹時血糖值とは特別の閣係は認められない, 合併症は白內障, 其他出血性網膜炎, 動脈硬化性の變 化が他のものよりも多い.

發病期を正確にすることは困難であるが，罹病年數の長いるのに尿異常所見を有するものが著明に多い (10年以上罹病者33例中19例)．10年以上でも暴常のないのは輕症か或は比較的によい治漝をしているものが 多い樣である.

腎臟機能檢查ては水試驗については昨年にも報告した樣に排泄の遲延, 濃縮力, 稀䆁力の低下を示するの ああるが中には萎縮腎樣のものもある. 檢查した全例ともフェノールスルフォフタレイン試驗は腎く，尿素 クリアランスは比較的よいるのああるが，兩者共 $50 \%$ 以下を示寸琹いるのもある.

以上吾が國の糖尿病患者中殊に其の罹病年數の長いるのの中に “diabetische Nephropathie”と思われ る腎障碍を伴 $ら$ もが多く，可成りの腎棬能の障碍があり獚沉な血管の障碍を伴うかに見えることは注目を 要する. 更に詳細な病態, 豫防, 治潦等について研究を淮めたい。

97. 糖尿病の腎機能に關する臨床的保究 第 1 報 インシュリンの腎機能及び糖尿に及ぼす影響

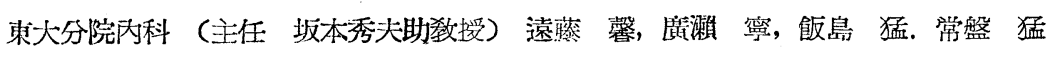

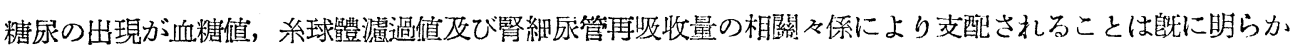
な事實である.我及は糖尿病患者14例に於てインシュリン(以下「イ」)腎機能に及ぼす影響について檢索を 試みた。

腎機能檢查としてはP.S.P.排泄試驗, 糸球體濾過值(G.F.R.), クレアチニンクリアランス(Ccr), 尿素

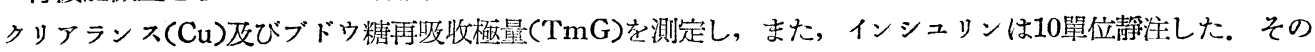
結論は次の如くである.

(1) 血栯㥀の高さ及び性別と TmGとの閒には一定の傾向をみと女なかつた。 
（2）比較的若年者群に於けるTmGは正常值より高值を示すのに對して高年者群の $\mathrm{TmG}$ 正常值よりも概 して低值を示す傾向が認められた。

（3）本症例はすべて「イ感受性で，これ等患者に於て「イ」感度とTmGとの間には特に差翼を認めなかつ た.

（4）本症例群に於ては明らかな䉰機能障碍患者はなく,「个淮射後に G. F. R., C cr, 及びTmGは概して並 行し增加した。

(5)「イ」注射後にGFRとTmG共に墰加するが，後者の堌加率が優位となるため糖尿は減少する.

(6) 糖㽷病の症狀の輕快と共にTmGは上昇を來した.

以上これを要するに「イ」の臨床的意義はブドー糖の體內代謝を支進せしめ血糖の下降を來すと共に二次 的に腎機能，殊に尿細管のブドー糖再吸收機能を上昇せしめ，尿糖は減少する。な招 TmGに及ぼす因子に 單に「イ」のみでなく諸種ホルモン作用もこれに關與していると考えられるが，この點に關しては今後の檢討 と共に報告する䂌定である。

98. 糖㽷病及びその他の疾患に於ける肝機能

$$
\begin{aligned}
& \text { 東京濟生中央病院 田中 岡三, 㫊柳 忠夫, 北村 信一, 片岡 邦三 } \\
& \text { 大塚 恒治, 鍋島 康嘱, 堀內 光 }
\end{aligned}
$$

（1）糖尿病及びその他の疾患について各種肝機能檢查，肝生檢組織所見，血清疍白傢豕びィンシュリン感 受性を檢查した．糖尿病に於ては血清總コレステロール濃度は牛數以上が正常值を示すが，高い值を示すも

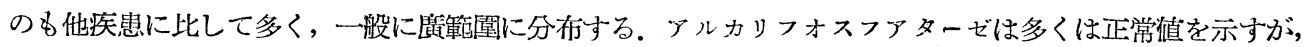
高值を示すものもある. チモール㴚濁反萑，ヶファリンコレステロール絮狀試驗は一般に正常で，血清總ビ リルビン量は少數例が高值を示 I.B.S.Pは15例中 3 例が輕度陽性を示した. 旰生檢組織所見には著變を認め 難い，血淸蛋白像は肝疾患と大體同樣の傾向であるが， $\boldsymbol{\alpha}$-グロブリンも增加するものが多い點多少異なる.

（2）糖尿病の中インシュリン感受型のものでは血清總ビリルビン量が高いものが稍々多いが，その他の點 ではインシュリン感受型と不感受性型との間に特に肝機能に差異を認め難い. 發病10年未滿のものの中には 肝機能障碍のあるものがあるが，10年以上のものにはそれが無い. 血糖の高さと肝機能との間には相経及係 は認め難い，糖㞗病を食慨及びインシュリンで治潦し，その結果糖代謝が著しく好轉したものでも肝機能檢 查成續は必ずしも之と本行しない。このことは糖尿病治潦上注意を要する事實と思う。

(3) 肝疾患に於ては一般にインシュリン不感受性を示し, 少數例が1/G1.3以上の值を示した. 治潦により 症狀輕快するに從いインシュリン感受性は正常となり，それと共に諸種肝機能檢查成續も改善した。

（4）肝疾患に於ける1/Gは肝㙨能の狀態に閵係深く，後者の改善と共に $1 / \mathrm{G}$ 正常に近づくが，糖尿病に 於ては $1 / \mathrm{G}$ と肝機能檢查成績とが必ずしも平行しない。之は糖尿病の病態が肝機能のみにより左右されてい、 るのではなく，ラ氏島よりのインシュリン分泌狀態或はインシュリン反對腺の狀態が大きく關與している䉆 と考えられる.

99. 各種內分泌疾患及者の Insulin 感受性立びに Insulin 投與時に於ける 抗利尿物質及び Melanophoren hormon について

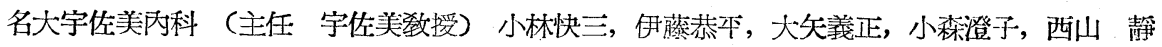

さきに私共は腎疾㭧者の Insulin (「イ」感受性立びに「イ投與時に於ける好酸球減少率(E)，血清抗利尿 物質 (ADS) 及び尿 Melanophoren hormon (MH) の消長について檢䇣し，腎疾患々下捶體副腎系との 關連性について郝告 (日本消化機病學會乘海地方會第 5 回例會) したが，今回は各種內分泌疾患者のそれに ついて檢討した。

實驗方法 前報告と同じく Perlmutter, Mufson 上にならい「イ鉒注法により「「イ感受性は Norgard- 
Thaysen 氏の同化率をもつて現し，ADSは Lloyd \& Lobotsky 氏法, MHは伊藤, 赤松氏法により檢定 した.

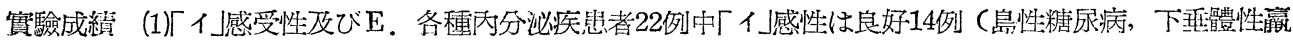
瘦症及び尿崩症各 3 例, バセドー氏病 2 例, 腎性糖尿, 亞急性播種性紅斑性狼瘡及び副腎機能不全各 1 例)

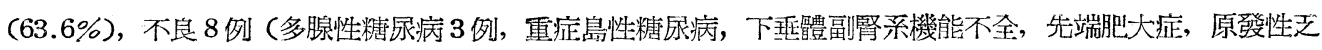
辰症及び多腺性內分泌腺障碍备 1 例) (36.4\%)を示し，他方 $\mathrm{E}$ （は正常10例(45.5\%)，異常12例(54.5\%)て

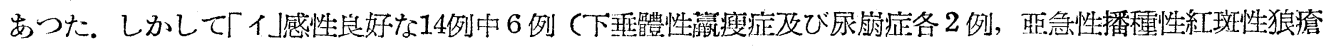
及び副腎機能不全各 1 例) は $\mathrm{E}$ ，異常を示L，一方「イ感性不良な 8 例中 E，正常な者は 2 例（重症島性及 び多腺性糖尿病各 1 例) のみであつた。

（2）血液ADS及び尿MH健康者では「イ股與後いづれも17至 3 時間後增量した。一方內分泌疾患者 (10 例11回) ではADSは 5 回 (45.5\%)，MHは 8 回 (80\%)に增量をみたが，その中正常域の增加を示したのは ADS. 4 回(36.4\%)，MH. 5 回(50\%)にすぎなからた. 次にADS.の分泌曲線はMH.のそれとは必ずしも一 致せず，乙かして兩者共に正常域增量を來したのは全例中 3 回 (バセドー氏病 2 例, 下垂體性赢瘦症 1 回)

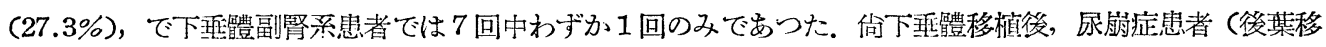

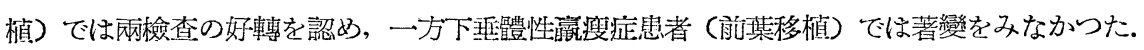

(3)「イ感性不良な多腺性糖尿病並びに下垂體副腎系機能不全㭧者各 1 例に「イ」, ACTH (20mg)同時注: 射を行つた所「イ」單獨時に比し「イ感性は更に惡化した。 しかしE. は兩例共に正常化し, ADS., MH. も亦後例では好轉を來した。

100. Insulin 感性に閵する破究 特に副腎, 甲狀腺との關係

東北大中村內科 赤坂喜三郎, 酒圭, 睦雄, 尾形 英雄, 伊藤 息雄

甲狀腺機能卉進症患者の Insulin 低血糖曲線を觀察すると Insulin 抵扰性正常の者, 抵抗性のある者, 或は一旦減少した血糖值が逆に注射前值より著しく上杽する者等があり，此等曲線の降下速度並でに恢復力 を調べた結果，甲狀腺機能充進症㭧者にはInsulin 抵抗性のある場合が多い事が睍れた。家鬼に甲狀腺 Hormon を投與し.て Insulin 低血糖曲線, 肝糖原, 副腎 Ascorbin 配含有量, 好ズダン性物質等の變化を みると，甲狀腺嘰能克進と共に Insulin 抵抗性の發現を認めたが，更に甲狀腺 Hormon を投與し肝糖原， 副腎 Ascorbin 配及び好ズダン性物質が減少するとInsulin 抵抗性は減弱し, 低血糖恢復能力が減少し, 特に低血糖症狀を認めた事は興味深い。

次に甲狀腺剔出家鬼の Insulin 低血糖曲線を觀察すると一般に降下速度は增加し，低血糖症狀を呈した ものもあつたが, 低血梼咴復力には著しい減弱を認めなかつた. Insulin 低血糖曲線と蛋白結合沃度 (PBI) との關係を二, 三の內分必疾㭧について觀察するにPBIが高值を示した例に於ては降下速度は減少し, 咴復 力は大であつた，又 Insulin 注射後血糖值の下降々共にPBIは一般に低下の傾向を示したが，その變化は僅 少であり，血糖曲線とPBIの變化とは必ずしも本行關係を認め得ない場合もあつた，以上の諸實驗を總括す ると甲狀腺は Insulin 低血糖曲線の恢復力增强作用よりも下降速度に關する力が大であり, 又甲狀腺 Hormon による抵抗性も副腎の關與により大きく影響されるものと考える. 又状亚機能艺進症患者に Insulin を注射した場合一旦減少した血糖值が著しく凟加する場合があるが，血糖做と PBI との關係から推 察して之を直に甲狀腺 Hormon の直接的作用とは考光難く, 斯る場合に副腎 Hormon が關係するのでは ないかと推察された。

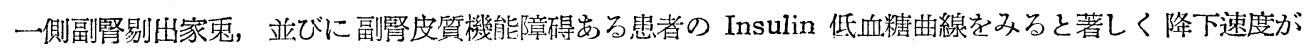
大, 咴復度小となり, 又 ACTH 投與により著しいInsulin 抵抗性を認めた善から副腎皮質は降下速度, 恢 復度に及ぼす影響は極めて大きいと思われた，又ッーン氏試驗とInsulin 低血糖曲線の上向脚とは一定の關 係むり，この上向脚の態度を觀察すれば下垂體, 副腎皮質機能の制定として意義少くないと考えられた。最 
後に結核患者及び結核家鬼の Insulin 低血糖曲線17KS，PBI との關係を追求し，更に結核と糖尿病との関 係を甲狀腺，副腎機能の面より觀察した。

\section{追加}

東邦大小兒科島田達 雄

血淸P.B.Iその他の測定により甲狀腺機能減退の診断を確定した症例につき Insnlin 感性を檢討した所對 稱10例中感受性の元進を示したもの 4 例で逆に抵抗性の發現を見たものを 3 例に見た．感受性の血糖曲線を 示したものは Epinephrine で血糖上最が低く，肝啸原の減量が敄想せられ，同時に施行した Thorn's Test で異常所見を示するのであつた，從つて甲狀腺の Insulin 感性は下互體一副腎系を介して行われるも のと敄想される。

101. 內分泌腺とインシュリナーゼ（第 4 報）

國立舞鶴病院 角本 永一, 福本 芳男, 葛山 楼清

Mirsky の所謂 Insulinase は各種內分泌腺と關連が深いことはすでに報告した。

今回は性腺を剔出して之の影響を檢したが，䍘丸剔出後筋インシュリナーゼと肝インシュリナーゼは健常 白鼠と大差ない事を認めた。

畉巢剔出後の肝並びに筋インシュリナーゼも健常白鼠と大差がない。即た性腺剔出は肝及び筋インシュリ ナーゼに對して影響のない事を知つた。

102. 自律神經劑のインシュリン作用に及ぼす影響について

國立舞鶴病院 角本 永一，福本 芳男，葛山 輝清

自律神經隲のインシュリン作用に對する影響を檢し，次の結果を得た。

1.ノイロトロピン・フアイナリンは正常家秘血䋖に影響を與えず，又インシュリン血糖降下作用にも影 響しない。

2、イミダリンは正常家央血糖を降下寸る例あるも大多數は變化せず，又インシスリン作用を墳强しない．

3.メトブロミン投與により正常家愁血糖が降下寸る傾向を示し， $0.5 \mathrm{cc}$ 每頭の場合が最も著明である. インシュリン血糖作用を增强し全例にショックを發來せしむ. 此のショックはアドレナリン投與により回復 せず，20\%葡萄糖投與により笔全に救い得る。

4.豫めルミナールを投與した家來に於てメトブロミンの作用は減弱する。

5. 三，三疾患及者及び健者に於てメトブロミンはインシュリン血糖作用を增强する。

103. 糖尿病患者に於ける「インシュリン」感度 特に皮下注射法及び偁脈注射法の比較に就いて

東北大黑川內科 齋藤 達雄, 共戶 辰男, 松島 恒男

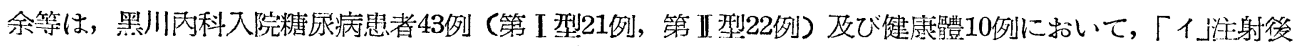
の血糖曲線を迫求し，皮下注射に依る場合と，靜脈注射に依る場合について，夫久比較檢討を加えた「イ」は， Squibb 製を使用，何れの場合も5 單位を注射，血糖測定は，藤田，岩竹法の淺利變法によつた，皮注法に

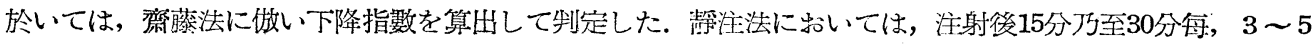
時間に亘る血糖曲線より, 同樣下降指數を算出して判定した。この際, 最低值の選定にあたつては, 最低值 前の血栯值との差が, $20 \mathrm{mg} \%$ 內の場合は, 後者を最低值と見做した。皮注法に依る下降指數は，健康體 の全例及び糖尿病の $47 \%$ \% 20以下(鈍感)，糖尿病の53\%は21以上(敏感)である. かつ第 $\mathbb{I}$ 型は敏感 $95 \%$ ，第 I 型は鈍感 $90 \%$ である。䣋注法に依る下降指數は, 健康體の全例及で糖尿病の14\%は1.91 2.50(正常感), $30 \%$ 2.51以上(敏感)，56\%は1.90以下(鈍感)である。かつ第II型の $41 \%$ 敏感， $27 \%$ は正常感，32\%は鈍 感で女り，第 I 型は19\%が敏感，81\%が鈍感で，正常感は無い。更に兩法を比輘するに，皮注法て敏感例も。 


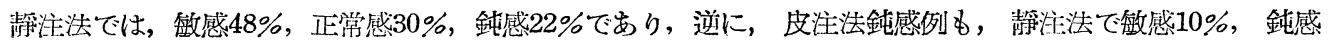
90\%，である，治潦後の變化をみるに，皮注法においては，不變乃至輕度の上昇を示するのか多いが，静注: 法に拁いては, 何れも正常感化する傾向が認められた。な拉, 皮注法に依る下降指數は, 注射後 $\mathbf{3}$ 時間の血 糖曲線より算出せられたもので充分代用し得ることを認めた，上上余等は，下降指數を以てする糖㽷病㭧者 の「イ感度試驗に際して，皮注法及び靜注法が，夫久獨自の特性と意義を有することを認めると共に，臨床 上治潦効果の制定には，皮注法がよく一敛することを指摘し，之が簡便法( 3 時間法)を提唱した。

追加 㼗問

東大冲中內科葛谷信貞

インシュリン正常感を健康人のインシュリン感性とし, インシュリン注射後の血糖下降速度をインシュリ ン感性の指標とする限り, 糖尿病にインシュリン超敏感はないと思います. この事は既に誌上に發表してい ます。糖疗病の空腹時血糖值は日久數 $10 \mathrm{mg} / \mathrm{d}$ l時には $100 \mathrm{mg} / \mathrm{dl}$ 以上の違いがあり, からる例について, 演 者のやり方で一定の下降指數が得られるか試みられましたか, 我及は糖尿病患者にインシュリン超敏感とい らわのはないと思つていますが極めて重要な問題でありますから壃重な研究を御原します。

要旨 黑川內科 齋 藤 達 雄

實驗例の一部において，血糖調節レベルよりインシュリン注射を施行して，感度を測定せるものあり，皮

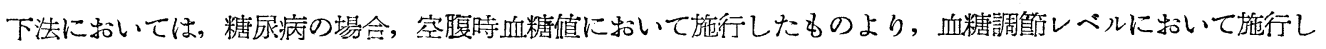

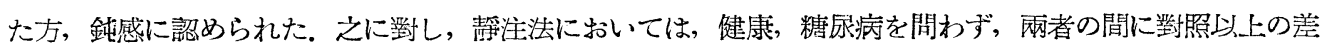

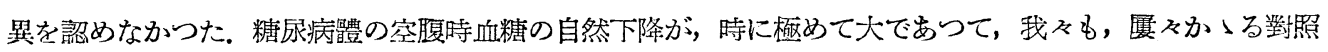
下降曲線を併施して, 補正曲線から, 下降指數を求めることもあるが, 感度の本質に關して, 差異を認める ことはない.

\section{追加}

國立舞鶴病院 角 本永一

糖尿病者空腹時血糖は非常に動摇するものがあるからインシュリン感度を研究する場合にはこのことを考

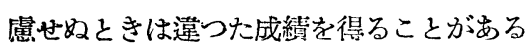

104. 經ロインスリン並びにベルスリンの効果

沼津市立病院 饭塚 直辰，松田 好正，豊田 三期

糖尿病にたいするインスリンの使用には幾多の變遷がある。生理的乃至診潦的最小最適量が重要であるの

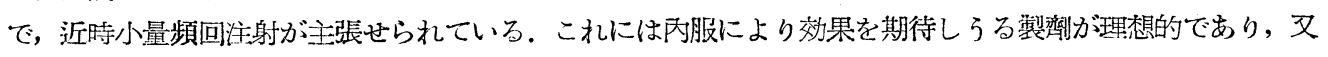

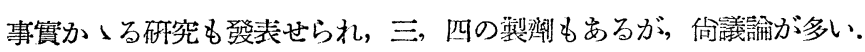

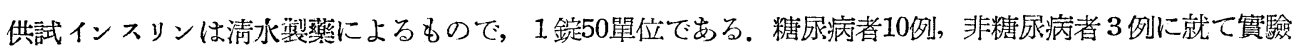
した. 更に栯尿病推移者の 4 例は食後に括ける血糖の推移を見た. 非糖尿病者では影響はない。糖尿病者 6 例は血糖降下乃至降下の傾向があり，4例は變化はなかつた。 內服以外舌下に留置して吸收を檢討したも の, ヒアロニダーゼと一緒にして腔內に留置したもの, 又膩汁粉て腸管を感作して後內服させたもの各 3 例 あるが，何れも變化はあらわれ如。非糖泿病者に作用しなからた事は, 小量では注射でも血糖降下眀かでな

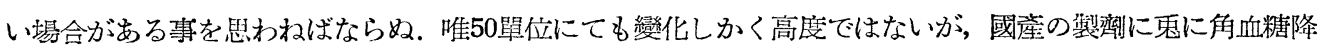
下作用を見大事は興味がある。如何にして腸內て變化をうける事なく，そのま】吸收せられる樣になすべき か心゙將來の問題である，ヒアロニダーゼ或は獎汁粉による晹管感作の試みる，からる見地に基づいたもので ある。

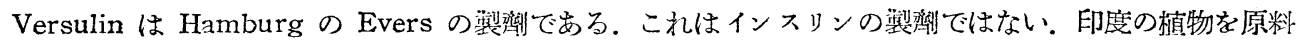
としたインスッン代用品である，糖尿病者 5 例について空服時檢すると，短時閣の實驗では血栯降下明かで

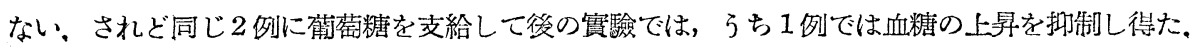


105. 糖疗病患者に於けるアドレナリン，インシュリン及び菊萄糖負荷後血液好酸球の變動に就いて 東北大黑川內科 矢內 統一, 服部 仁, 菅原 豊次

當科入院糖尿病㭧者 33 例及び健康對照 12 例に就き, アドレナリン，インシュリン及び藏萄糖の負荷後, 夹 々の場合に就き，血液好酸球數及び血糖值を 30 分每 5 時間に亘つて迫求檢討を加えた。 アドレナリンは 1000

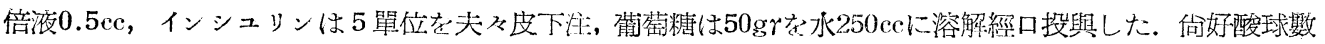
㔍定はRandolph の法に從い，血糖值測定は藤田一岩竹氏の淺利氏變法によつた，好酸球數值はそれ自身 Poisson 分布を示すため, V不變換法により變動曲線を表した.

血液好酸球數の變動は一般に多相性經過を示し，アドレナリン負衡の埸合は，初期に增多(初期增多)を示 し，次いで減少(次期減少)を認めるものが多いが，第II 型糖尿病は，第 I 型糖尿病に比し，初期增多時期が 速かに現孔且增加率も大なる傾向を示した，最大次期減少を示す時間は，30分より 5 時間に亘り，4時間に 一致するのはその一部に過ぎなかつた，最大減少率も，第型糖尿病は第 I 型に比して大なるものが多いの

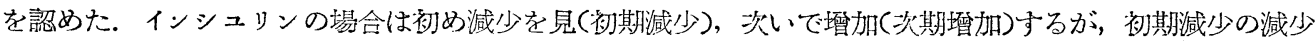

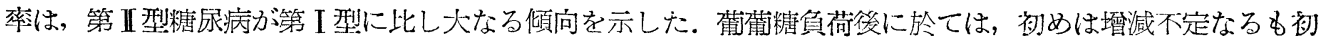
期減少を示すもの䅌々多く次期增加に移行寸る．之等の好酸球變動は，直接血糖值變動の影響を認めないが， 蓪萄糖負荷の場合は，血糖恢復時と好酸球の次期增加開始時期とが略々一致する場合が多く認められた。

以上の所見は，必ずしも糖㽷病に獨自の所見とは斷定出來ないが，少くとも第 I 型梼尿病に比して，外部 よりの刺钱に對する生體の反隹がより歓感であると考えられる。

106. 糖尿病患者のインシュリン血糖下降時に拈ける心電圖

慶大內科 (主任 大森㸚授) 山口 與市, 本田 正館，橋本 康夫，國分 豊明

糖尿病患者は食餌潦法並びにインシュリン治潦により生命が娫長されて居るが，糖死病に罹㭧して約 10 年 以上經過すると血管系の變化がおこるが，血管系の變化は特に仜險なものである．糖尿病患者にインシュッ ン治潦を行うときに胸內苦悶感を訴えるものがあることよりインシュリンにて高血糖より低血糖に至る間に 心電圖が如何に變化するかを檢浔した。

檢查方法车び檢查對照 此較的老年者11名を含む13名の糖尿病㭧者にインシュリン4〜5盟位静注して血 糖を下降せしめ，その際の心電圖を30分間隔で 2 時間迄時間的推移につれて檢索した. 又これらの檢查に本 行して可能なる範虽にて血溜カリウムの測定を實施した．檢查を行つた糖尿病患者に高血壓のもの，ワッセ ルマン氏反隹陽性のものはなかつた。

檢查成浿 心電圖の所見として著明なるものは，STの降下，Tの平低乃至陰性化及びu波の出現とであり; これらはインシュリン靜注後30分，60分に特いて最も頻度が多かつた。.

以上の心電圖の變化は血糖の絕體值及び血清カリッム值と特に關係はみ女たらず．インシュリン注射によ り著明に ST及びT の變化を示した症例にアドレナリン0.5ec を皮注したが，インシュリンのときと同樣の 心電圖所見を得た。このときは勿論高血厴を示した.このことから，インシュリン自體のもたらした變化と いらよりもむしろインシュリン注射により誘發されたアドレナリン分泌の効果とも考え得られる。カリウム の值に變化を認めるが，低カリウム血症或は高カリウム血症に特有の心電圖變化は認められなかつた。

追加

國立舞鶴病院 角本永一

アロキサン糖尿家鬼の低血糖時にT及びST波に戀化めることを㭱に本會に於て發表してょる。

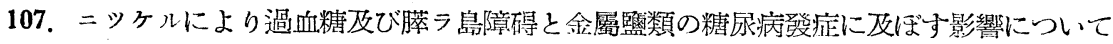

大阪赤十字病院醉科 栗田滿太毁, 門田一郎

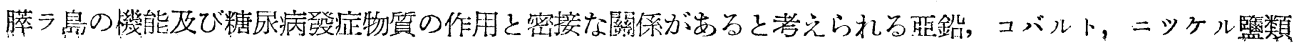


の血糖及びラ島細胞に及ぼす影響を家東に於て檢討した，その結果亞鋁では著變をみなからたが，ニッヶル，

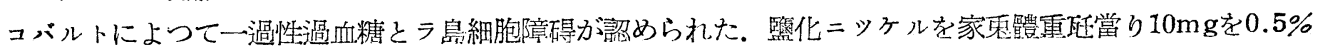
水溶液として签注すると11例中 6 例に過血糖を見, $15 \mathrm{mg} / \mathrm{kg}$ では 7 例中 6 例, $20 \mathrm{mg} / \mathrm{kg}$ では全例に洏血糖

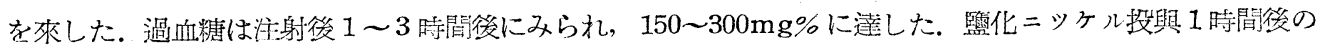
膵ラ島細胞を Gomori 染色によつてみると正常のラ島細胞の排列が失われ， $\boldsymbol{\alpha}$ 細胞は多く周邊にだけ整め

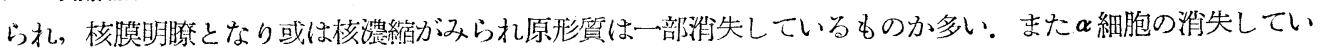
るラ鳥や周邊部に僅かに殘存しているものもあつた。 $\beta$ 細胞は正刻の原形質顆粒沙失して睡大し核の濃染し たものもあつた：このようなラ島細胞障碍はジェチルジチオカルバミン酸りーダによる $\alpha$ 細胞破壞及で監化 コバルトによるラ島變化と類似している. Goldner らは監化コバルト $40 \mathrm{mg}$ の投與により大部分の家東で過

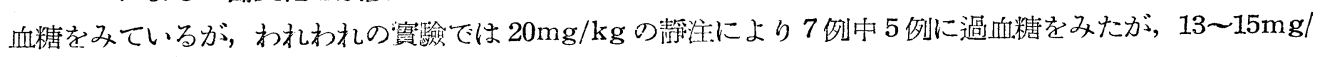
$\mathrm{kg}$ の投與では殆ど一濄性の過血糖を認めなかつた。 コバルト投與例のラ匐細胞の變化は $\alpha$ 細胞の變性，消

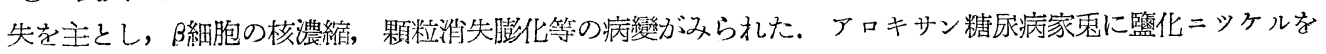

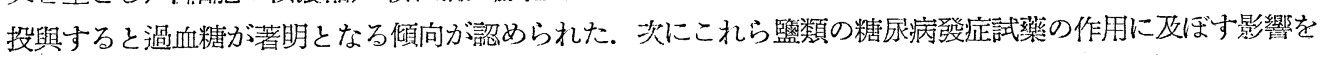
檢討しエチルキサントゲン酸ヨリウムの發症作用はよく抑制され，アロキサンの作用も抑制される場合が放 られた。

108. 䌅尿病患者の「トルコ鞍」

弘前大松永內科 早川 光久, 三上亮次毁, 安田莊十郎, 木村 武一

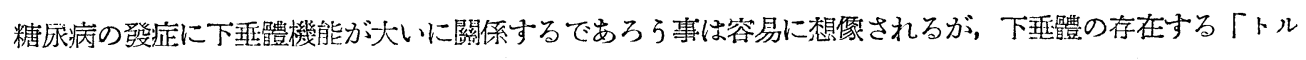
コ鞍」の大小と，糖尿病との閣係に就て明らかにされた處は殆んどない。

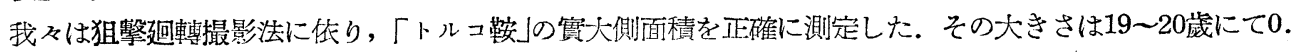
$82 \mathrm{~cm}^{2}$ に達し, 以後發育はみられず, 成人健康者斥均值は $0.81 \mathrm{~cm}^{2}$ であつた。低而我々は $0.82 \mathrm{~cm}^{2}$ を限界々 して46例に於ける成人糖㲾病患者の「トルコ鞍」側面積を二分した。更に發病年砱30歲を限界として, それ 以前に發病した者を若年者群，それ以後に發病した者を高年者群とした。

若年にて發病せる群 (10例) にては,「トルコ鞍」の大小に拘不，血糖高く，泉所見も多いが「トルコ鞍」 大なる者 (2例) は肥つて法り, 合併症 (肺結核・腎炎・白內障)なく, 病勢の淮行も緩徐であるに反し, 「トルコ鞍」小なる者 ( 8 例) は合话症も多く, 病勢の進行も極めて急速である. 叉, 高年にて發病せる群 (36例) にては,「トルコ鞍」大なる者 (22例)は一般に血糖高く, 尿所見も或琹度著明であるが, 病勢の進

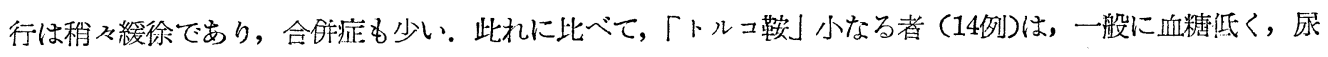
所見も少い。垪し合併症多く, 病勢の淮行も稍及急速である.

佮, 輕度の貧血は10例に認められ，その中，6例は「トルコ鞍小なる高年者であつた，又，「インシュリ ン」感性, 並に Thorn 氏テストに就ては, 未ナ゙明らかなる傾向は認めら机難く, 目下追求中であります.

要するに「トルコ鞍」小なる糖苌病㭧者 (22例) は, 決して稀なるものでなく, 殊に下画澧系の關與如何 に依り，梼尿病の本質に大きい差暴を生ずる事を示唆して興味深い。

\section{追加}

國立舞鶴病院 角 本永一

若年者糖业病で下垂體容積の小なるものことに贏溲せるものでは空腹時血糖の動摇は著明であることが多 い.

逭加 浴風會東大冲中內科 村 池 悌 二

冲中內科に於て嘗て，糖尿病患者のトルコ鞍を，單純撮影により觀密した際一見，トルコ鞍の茥だ小さい 場合には尿糖の如何にからわらず，尿量が少い事實を認め，昭和26年本總會に報告した。 
109. 緗合アミノ酸の結合血糖に及ぼす影響（第 3 報）

$$
\text { 北大山田內科 山 田 正 }
$$

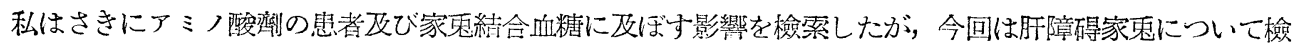

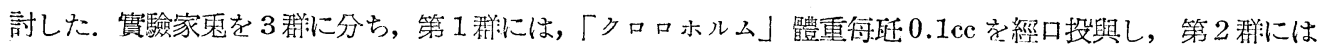
「ク」投與 24 時間後 $10 \%$ アノ酸液體央每聒を 5 日間連續注入し, 第 3 群はアミノ酸 1 週間注入後「ク」を 投與し，遊離血糖，結合血糖及びヘパトサルフフレイン值 (HSP) を測定した結果，第 1 群では結合血糖は 2〜3日で最高となり，7〜8日目に鹪值に復した，遊離血糖は第 1 日目に最低となり，徐々に上舁して 7 〜8日間で前值に復した。

HSP值は第 1 日目に最高となり，結合血糖値と本行して低下した。

第 2 群では結合血糖はアミノ酸注入後 2 時間目に最高となり，急速に下降し，第 1 郡に較で短期間 ( 4 〜 5 日) に前值に復した.

又「ク」投與により下降した遊離血糖は铋速に上昇し，4〜5日目に前值に復した. HSP 值も第 1 群に 較べ速かに改善された。第 3 群ではアミノ酸注入期間は血糖值及び HSP 值に著しい變化は認められない. 「ク」投與後結合血糖は僅かに上昇し，遊離血糖は稍々低下すが，兩者ともに2〜3日で前值に復した。 HSP值も結合血糖值と平行して速かに正常值となつた。.上の篔驗成績から

1）肝障碍時には結合血糖は高值を示し, 肝障碍の恢復とともに正常值に復する.

2）肝障碍時にアミノ酸劑を岐與すれば，結合血糖は一椇性に上昇するが，後速かに下降し，短期間に正 営值となり, 肝機能の恢復も早い.

3）豫めアミノ酸劑を投與し，肝を障碍する場合は，結合血糖の上昇は輕微で，肝障碍も亦䡒度である。 郎ちアミノ酸鴟は肝機能を疪護すると同時に結合血糖を正常化する。

\section{Alloxan 糖尿に關与る磁究}

電解質より觀た發症期に於ける副腎の關與に就いて

\section{京府醫大細田內科 塚本 勝, 伊地知濱夫}

糖代謝及び電解質代謝と副腎機能との關係を迫求せんとして，アロキサン糖尿犬並びに副腎剔出後にアロ キサンを負份した犬に於いて，血糖及び二三血海電解質を測定して次の結果を得た。アロキサン糖尿犬では 血糖は三相性の變化を示し，血淸 $\mathrm{Na}$ 文びKは減少後前值に復する傾向をとり，血清 $\mathrm{cl}$ は輕度ではあるが 減少後增加を示した，次に副腎剔出大では血糖は低血糖を示し，血清 $\mathrm{Na}$ 及び $\mathrm{cl}$ も亦減少又はその傾向を 示し，血清Kの增加が見られた，上述の實瞼成續によつて副腎は糖並びに電解質代謝の變調に重要な役割を 演じていると考えられる，次に兩側副腎剔出犬及び偏側副腎剔出犬にアロキサン栫尿を惹起せしめた場合の 變化を浦べんに，偏側副腎剔!出犬は血糖及び血淸 $\mathrm{NaK}$ 及び $\mathrm{cl}$ の量的變動は上述アロキサン糖尿犬と略及 等し所見を呈し，これよりも稍々輕度であつた. 又兩側别出犬では趣を異にして過血精をみることなく低血 糖を來し漸次經過と共に高度となり，血清 $\mathrm{NaK}$ 灭び cl には正常犬の夫等に比して著變が見られなかつた。

以上の成綘より Alloxan 糖尿に於ける糖質並びに電解質の代謝異常は副腎を介して行われているもので あると考えられ，從つて電解質の面からも，アロキサン糖㞗發症には副腎㙨能が重要な役割を演ずることを 推論すべき結果を得た。

\section{追加}

九大楠內科本界幸正

Alloxan を15匹の正常家雨に僼重 $\mathrm{kg}$ 當り $200 \mathrm{mg}$ 静注し，8匹の正常犬に體重 $\mathrm{kg}$ 當り100mg静注した。 この際，血清內カリウムは初期過血䌒期に於て，家鬼では堛加するものが多く，犬では增加と減少とが相牛 ばした，次の低血糖期に於ては，家鬼も犬も共にその大多數に血清內カリタムの著明な減少を認めた。

侗，腎剔家鬼に於ても Alloxan 注射により血清內カリウムは正常家鬼と同樣な變動を示した， 
又家雨にアドレナリンとインシュリンを皮下注射寸る事によつて，その血精曲線が Alloxan 注射時と似 よつた經洞を示した時の血清內カリウムは, 血梼の上昇期と下降期を通じて常に減少のみを示した。

111. 水電解質代謝 2 內分速（第 1 報）インシニリン投與時の電解質と心電圖の變動

乘大田坂內科 吉 利 和, 長畑一正, 北村 勇, 遠藤 義男, 花岡和一郎 不田 信雄, 織田 钽次, 上野 幸久, 前田 貞亮, 高橋 政夫

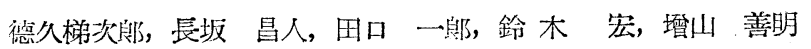
福島 秀夫, 中帛 弘道, 宮下 英夫. 清水 直畲

東大神經科 島薗 安雄, 佐藤“倚男, 犲場 令人, 黑川 正則

インシュリン使用時の電解質變動はと久に明かとなりつくあるが，インシュリンショック時の變動につい ての知見は少い。我及は神經科入院㭧者 8 例の內男子 5 例女子 3 例に 14 回の檢查を行い, 次の成續を得た。

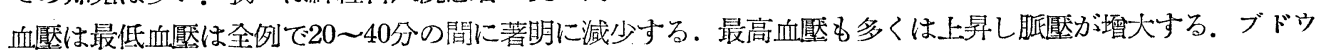
糖注射前に血厴は回復を示しはじめるが，注射後は速かに前值にかえる．血糖は20〜40分の閏に最低40〜10 $\mathrm{mg} / \mathrm{d} l$ に低下し，ブドー糖注射まで續く，腦波は血糖變動とよく一致して變動し血糖が下り出す頃刺㦸によ

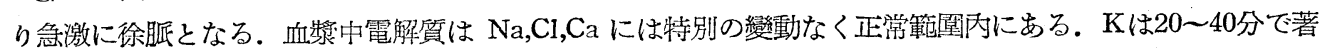

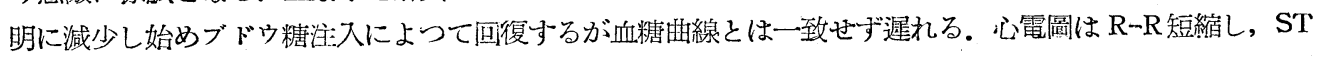
間短縮，T波は前進し，本低下寸，U波の巾高さとも增大が認められ，QU が延長する。低カリウム血に一 致した變化と考えられるが，細胞內外のカリウムバランスも考慮されねばならない，緊血行力學の觀密では

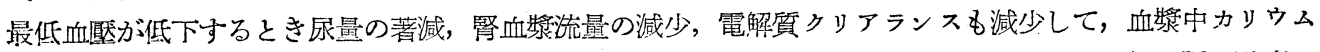
の減少が細胞內區への移行によるとの說に根據を提供した。右心カテーテル法によると混合靜血脈の酸素は

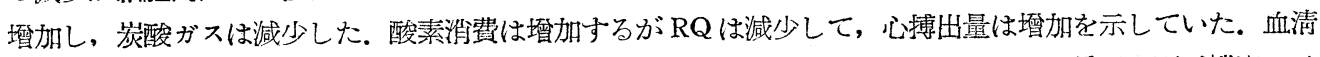
中無㙨燐はインシュリンにより著しく低下するが，更にブドウ糖注射により著減した. 昏睡の遷延機序に示 唆深いものであると思われる.

\section{追加}

九大楠內科·平田幸正

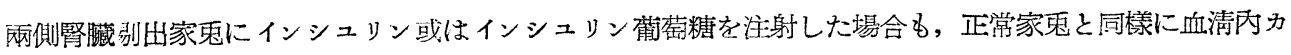
リシムは低下した。

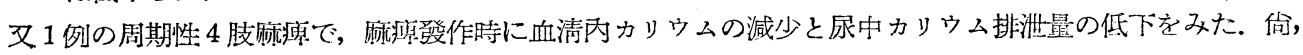
谳湶發作時血清內カリウムは2.5meg/1であり。心電圖でT波の低下とU波の出現をみた。

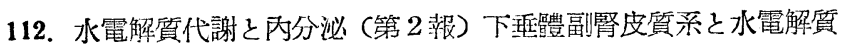

$$
\begin{aligned}
& \text { 東大田坂內科 吉 利和, 北村 勇, 遠藤 義男, 花岡和一㣀, 不田 信雄 } \\
& \text { 前田 貞亮, 高橋 政夫, 德久悌次毁, 長坂 昌人, 田口一埧 } \\
& \text { 份藤 智, 增山 善明, 福島 秀夫, 清水 直容, 宮下 英夫 } \\
& \text { 東大整形外科 川村 次毁, 橫關 嘉伸 }
\end{aligned}
$$

主として ACTH, コーチゾンを用いてロイマその他の患者の水電解質代謝の長期及び短期の變動を筧つ た. 先ず電解質代謝に對しては速い電解質利尿効果と腎外性の特に細胞からのカリウムの㹂失, それから反

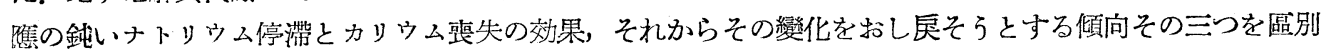
した，そして所謂 re-bound 効果とは最後の傾向の行き過ぎではないかとした。

水分代謝については短期にめつては循環血漿量の減少, 長期にあつては全體水分の增加, 細胞外液 (ロダ

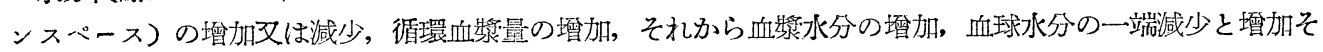
れと本行するへマトクリット，不定の全血水分を見た，又腎㙨能として腎血漿流量，口办值は電解質クリカ 
ランス，水排洲の垻加にも拘らず影響がなかつた。

質問

岐皋市司町岐醫大三宅內科大高 道 夫

健康者約80例に就て Beckman Flame Photometer にて測定せるNaは本均 155mFq/1 の高值を示しま したが貴下の測定本均御㸚示願えれば萃甚に存じます。

解答

東大田坂內科吉利和

正常人の血䊢中 $\mathrm{Na}$ 濃度は約 $140 \mathrm{mFq} / 1$ 万法は Lange 型の火焰比兒計，除蛋白は行つていない。

質問者のいわれる $150 \mathrm{mFq} / 1$ 以上といら高濃度の理由はよく分らない。

113. 水電解質代謝と內分泌（第 3 報）下琵體後葉 (ADS) と水電解質

東大田坂內科 吉 利 和, 北村 勇, 遠藤 義男, 花岡和一期, 不田 信雄 前田 貞宽, 高橋 政夫, 長坂 昌人，德久梯次郎，田口一郎 增山 善明, 福島 秀夫, 齋藤 穎, 宮下 英夫, 清水 直容

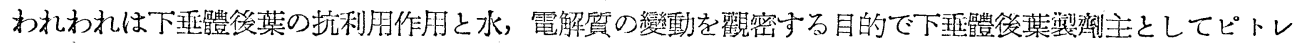

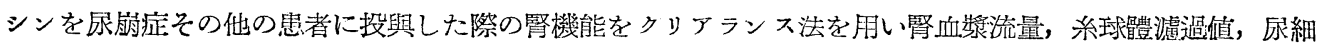

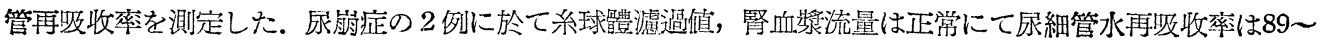

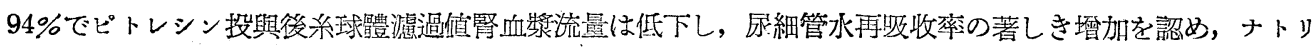
ウム, クロールの濃縮力增大を認めた。腎機能正常者に水試驗を行いピトレシン及び12時間水攝取を中止し

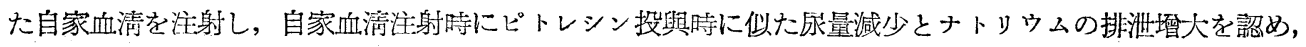

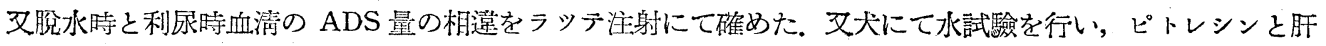

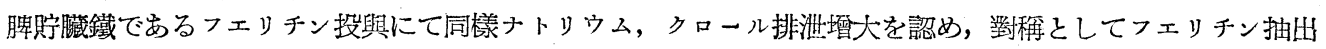
の際使用した硫酸カドミウムを單獨投與したがナトリウムクロールの排洲增大を認めなからた。

犬にて下空涂脈を陝窄し腹水を作つたが腹水貯溜傾向の 際はナトリウムの 尿中排泄は著しく減少し血清 ADS 量も增大するが貯溜が極限に達すると.尿中ナトリゥム排泄は恢復するに拘らず血清 ADSはむしろ增大 傾向を示しついで減少した。

114. 水電解質代謝と內分泌 (第 4 報) 锤夜腺ホルモンと水電解質

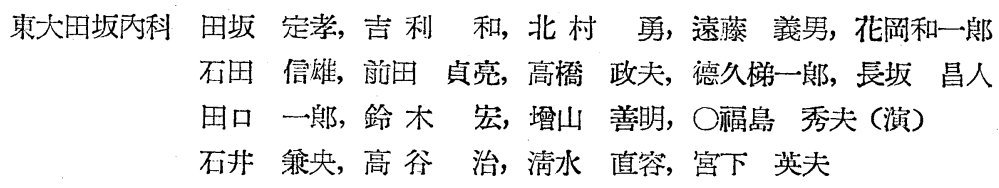

睡夜腺ホルモン (パロチン) は血清カルシウム低下作用のある事が明らかにされ，血清無機燐，血清マグ ネシウム等の電解質に仗ぼす影響，及び水分代謝に閣し報告があり，又一方パロチンに，ACTH 樣作用の める事が見出されている。われわれはこつに水，電解質一般の代謝に及ぼすそれらの影響を總合的に觀察し， 更にその調節嘰構を追求せんとした。

電解質代謝に關しては，血獎中及び尿中ナトリウム，カリウム，クロール，カルシウム，立びに血漿中無 㙨燐，水分代謝に關しては賗總水分量，細胞外液量，循環血漿量，を測定した。

I ) 短期の觀察 (郎ちパロチン 1 回䇟肉內注射時の變動)

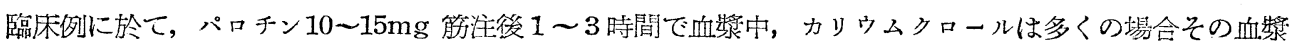
濃度は上杽し，ナトリウムもクロールに立行して僅かながら上昇した。實驗動物，犬では Prokilo 0.5〜 3mgで之等電解質血墏中濃度は何れも一定の傾向は見られなかつたが，これはパロチンの注射量に閣係せる 
かと思われる。

血漿中カルシウムに關しては, 臨床例, 動物實驗何れも從來云われている如く一般に血獎中濃度の減少を 示したが，比較的大量のパロチンを注射せる場合は却つて上昇を示した例る觀察された。

水分代謝では， 2 例に於て，細胞外液の墰加，文び全血水分％，血漿水分％，血球水分\%が何れる注射後 3 時間で增加し, 尿中變化では, 注射後 3 時間で永量減少, 尿中カルシウム濃度の上昇, 及び尿ナトッウム, カリウム,クロール排泄量の減少を見た.

II) 長期の觀察 (即セパロチン連注時の影響)

血小板減少性紫斑病に於て, 血獎カルシウムは $10 \mathrm{mg} 9$ 日間連注で次第に減少を示し, 屁量は一時的減少 の傾向が見られた. 又尿崩症では尿量に著明な變化は見られなかつた.

115. 水及び電解質と內分泌機能（第 1 報）尿崩症患者に於ける觀察

慶大大森內科 山口 與一, 那須 嘉輝, 土居 克己, 衛藤鐐三郎, 加藤 暎一, 橋本 康夫 欲田 良作, 小島嘉三郎, 柴田 貢, 國分 豊明, 山內 真

尿崩症 2 例につき水, 電解質代謝字檢索した. Pitressin に反潐せず，下垂體後葉埋没が奏効。埋没後㞗 量減少し $(5 \sim 91 \rightarrow 11)$, 比重高まる. 埋没後14〜18時間排尿を要しない. 飲量は尿量におくれて減少す, 効果は 1 例は 3 週間, 他は 4 週間持續する. 再發時には低比重鸨, 多尿, 多飲の順序. 埋没前公共基碟代謝 正常範阐, インシュリン感性良好. Thorn のテストで1例は ACTH に反㗹よく, アに反㗹弱し。他は兩 者に反㗹充分でなく, 前葉機能は正常又は稍及低下. ACTH 注射後 3 時間渴感なし, 但し尿量は依然多し. 血清 ADS 正常簌䦔.

8 時間飲食を禁ずれば尿中 $\mathrm{Na}, \mathrm{Cl}, \mathrm{K}$ の濃度幾分上昇, 但し $\mathrm{Na}$ は血清濃度に達せず。8 時間中の水分垔

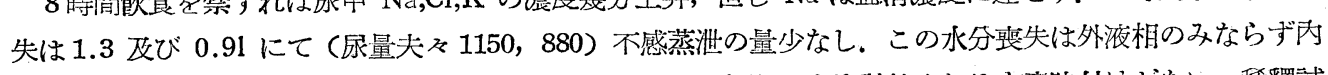
液相からも由來するが程度は一樣ならず。 Na, K の內外液相間の出入計算されるも意味付けがない, 稀釋試 驗にて埋没前は過利排泄を，埋没後は不良排泄を示す，濃縮力は前に惡く後に改善.

Cortisone 注射により尿量は變化なく多尿. 比重一時高し. 17KT, Corticoid 激霄. $\mathrm{K}$ および $\mathrm{Na}, \mathrm{Cl}$ む

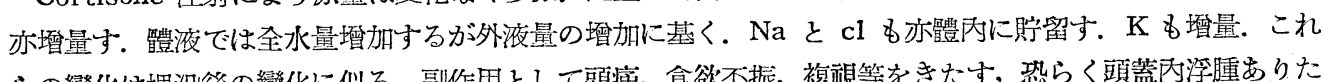
らの變化は埋没後の變化に似る。副作用として頭痛，食欲不振，複視等をきたす，恐らく頭等內浮腫むりた

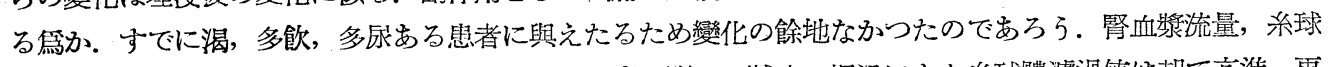

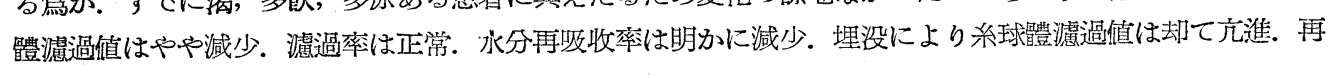
吸收正常に高まる。

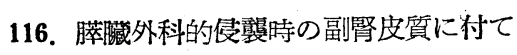

阪大第一解剖 指導高木㸚授, 大野 良雄, 辻 . 甲

副腎皮質機能の研究は最近頓に盛んとなつて來ましたが，私共は膵臟との關係を細胞形態學の見地に立つ て迫求するために犬を用いて膵の部分切除を行いました結果を御報告申上げます．惯驗動物は體重 $10 \mathrm{~kg}$ 雄 成犬を用い，實驗の種類として第 3 群に分類し，第 1 碓には膵頭部より政切除後 3 日， $1 \mathrm{~W}, 2 \mathrm{~W}, 3 \mathrm{~W}$, $4 \mathrm{~W}$, 第 2 群は膵尾部より经切除䒺 3 日, $1 \mathrm{~W}, 2 \mathrm{~W}, 3 \mathrm{~W}, 4 \mathrm{~W}$, 第 3 群は膵尾部より结切除後, 3 日，

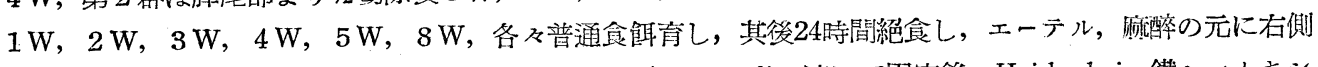
副費より取材し, Kalster 氏液, Zenker 氏液, 15\% Formalin 液にて固定後, Heidenhain 鐵へマトキシ リンーヘマトキシリンーエオデン，Scharlachrot 染色を行い，組織學的に研案致しました結果，膵险を部 分切除しますと，

1 副腎皮質の束狀層を中心として，俄に細胞の形態變化が起りますそそれは胞體に充滿していた脂肪の 放出で在り，しかもそれが高度の場合には或る稍度の崩壤が考えられます.しかし早晚束狀層は, 正常に歸 
ります。

2 頭部切除は尾部切除に比して，副䝳度質特に束狀層に大きな影響を與えます。

3 今回私共の行いました實驗の中では，膵尾部彷切除が最も著明な影響を與え，その反㗹として，正常 を上迴る脂肪の蓄積傃が見られます。

117. 糖㽷病の治療と尿中ケトステロイド

多大日比野內科 向并 長男, 不垣 健一

糖尿病に於ける尿中 $17 \mathrm{KS}$ の排泄量に就いては諸家の報告があるがインシュリンにより治潦を受けた糖尿

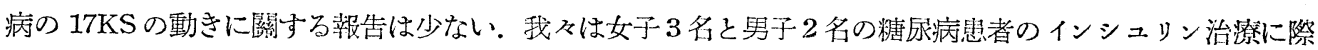
して血糖の下降を含めた一般狀態の改善と並行して $17 \mathrm{KS}$ が正常值又はそれに近ずく事を長期に亘つて觀察 した.

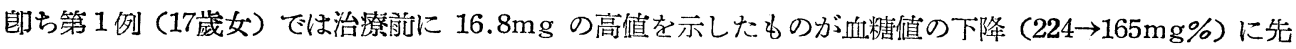
行して $17 \mathrm{KS}$ は一旦 $9.2 \mathrm{mg}$ 迄下降したが頁に高單位(40單位)のインシュリン投與により再び15.2mgと上 昇し，その後血糖の下降と共に減少して血糖值 $135 \mathrm{mg} \%$ の頃には $17 \mathrm{KS} 5.6 \mathrm{mg}$ と正常值に徣した. 第 2

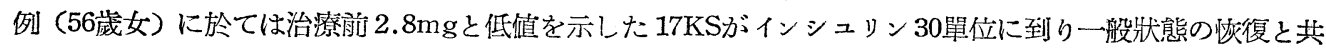
に念激動き血糖值當初 $208 \mathrm{mg} \%$ が $116 \mathrm{mg} \%$ に減少する頃には $4.2 \mathrm{mg} \sim 5 \mathrm{mg}$ となつた. 第 3 例 (43歲女) は肝硬變症を伴なつた糖层病の例であるがインシュリン治潦と共に當初 1〜2 mg だつた $17 \mathrm{KS}$ が次第に增 加し一般狀態か改善するに從い $17 \mathrm{KS}$ む〜 $6 \mathrm{mg}$ 沦墖加し血糖も $246 \mathrm{mg} \%$ 上り $146 \mathrm{mg} \%$ に迄下降した が其の頃より腹水夥涿著しく肝硬變症に体な弓症狀琹化し來つて血糖は佮も $104 \mathrm{mg} \%$ 汽減少を續けたが己 に 17KS の動きはなく1〜2.6mg を上下する樣になつた異常例でインシュリン治潦開始後40日にして死亡 した．第 4 例 (23歲男) では治㳽前の血糖 $251 \mathrm{mg} \%$ が炏第に下降すると共に低值を示していた $17 \mathrm{KS}$ (當 初3〜6.4mg) が血䊕值 145mgに汽減少した頃には 6 14.4mgに迄墰量した。第 5 例 (57歲男) は肢端肥

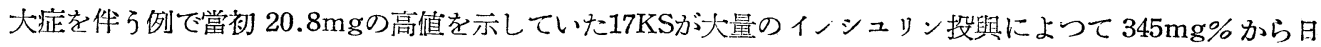

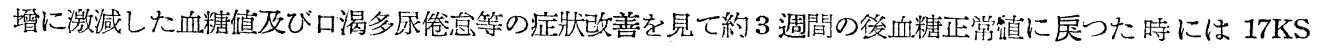
12〜13.6mg となつて居る.

以上の如く糖尿病に於いてはインシュリン投與により症狀の改善そして血糖值の正常化と共に尿中 $17 \mathrm{KS}$ の排泄量も正常化する事が認められるこの事はインシニリン投與によつて充分效果的にステロイド代謝の面 に於ける Hormon Balance が回復して來たと洘えられるかも知れない，そして糖㲾病に於ける Soskiu 等 の主張する或る種の肝機能の異常とステロイド代謝に於ける肝臟の役割を思い合せるならばインシュリン投 與によつて肝機能のからる意味に於ける正常化が諸種症狀の好轉並びに血糖值の正常化そして尿中 17KS排 洲量の正常化に最も重大な役割を演じているかと洘えられない事はない郎ち糖虔病に於いてインシュリン投 與は肝贜を中心とした代謝に顯著に影響する事を暗示して居るのかる知れない。 